



University of the State of New York

$$
\text { B.U L L E T I N }
$$

OF THE

\section{New York State Museum}

Frederick J. H. Merrill, Director

$$
\text { VOL. } 6 \text { No. } 29
$$

October 1899

PRELIMINARY LIST

OF THE

\section{MAMMALS OF NEW YORK}

BY

GERRIT S. MILLER JR

\section{ALBANY}

UNIVERSITY OF THE STATE OF NEW YORK 


\section{CONTENTS}

Introduction

History of the list of New York mammals............. 273

Type localities in New York..................... 279

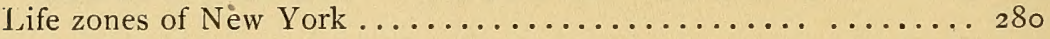

List of mammals . . . . . . . . . . . . . . . 292

Explanation ......................... 292

Recent species......................... 293

Fossil species .......................... $37^{2}$

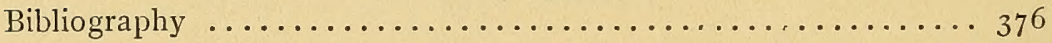

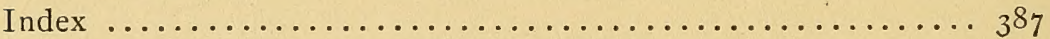

\section{Note BY THE DIRECTOR}

The long period of time which has elapsed since the publication of De Kay's report on the zoology of $\mathrm{New}$ York in $\mathrm{I}_{442}$ and the great progress of systematic zoology during that interval have made it important for the New York state museum to issue a systematic description of the New York mammals at present known. In seeking for some one properly equipped to prepare this important contribution, the director was brought, through the courtesy of Dr C. Hart Merriam, into communication with Gerrit S. Miller jr, who has undertaken and completed the work.

As the editing rules in bibliography, ${ }^{1}$ adopted by the Regents of the University of the State of New York, are materially different from those which Mr Miller is in the habit of following, he has asked to be relieved of all responsibility for any errors that might be introduced in the editorial revision of this part of the work. The director takes pleasure in relieving Mr Miller from this responsibility, though he believes that sufficient care has been taken to make the work entirely reliable.

Frederick J. H. MerRiLl, Director 

$\cos x^{2}+x^{2}+x^{2}$ 


\section{Preliminary list of the Mammals of New York}

\section{INTRODUCTION}

At the suggestion of Dr Frederick J. H. Merrill, director of the New York state museum, I have prepared the following preliminary list of the marnmals of New York. To write a preliminary paper on this subject I4 years after the appearance of Dr C. Hart Merriam's two volumes on the mammals of the Adirondack region, and $5^{6}$ years after the publication of De Kay's elaborate work on the mammals of the state at large, may at first seem paradoxical. Nevertheless one of the most important results of the recent great increase in our knowledge of the mammalian fauna of New York is the realization that nothing more than preliminary work can be done now. The whole area of the state must receive a thorough biologic survey before final results can be expected. To aid in preparing the way for such a final investigation is the main purpose of this paper. My aim is to bring together the scattered published knowledge of the subject rather than to add any considerable mass of new facts.

\section{HISTORY OF THE LIST OF NEW YORK MAMMALS}

The first important work on the mammals of New York was published by DeKay in $\mathrm{I} 842$ as part one of the Zoology of Neze York. ${ }^{1}$ In this work 70 mammals are recorded as forming part of the natural fauna of the state. Seven of these, Didelphis virginiana, opossum, Sorex parvus (=Blarina parva), small shrew, Sorex carclinensis (=Blarina brevicauda carolinensis), short-tailed shrew, Arvicola xanthgnathus (=Microtus xanthognathus), yellow-cheeked meadow mouse, Rangifer tarandus (=Rangifer caribou), caribou, Rorqualus borealis (=Sibbaldius borealis) silver-bottom whale, and Delphinus delphis, porpoise, are included without definite knowledge of their occurrence within the boundaries of the state. Eight others, Sorex dekayi (=Blarina brevicauda, short-tailed shrew), Otisorex platyrhinus (=Sorex personatus, masked shrew), Mustela fusca (=Putorius richardsoni cicognani, Bonaparte's weasel), Sciurus niger (=black phase of $S$. carolinensis leucotis, northern gray squirrel), Mus americanus ( $=M$. rattus, black rat), Arvicola hirsutus (=Microtus penn- 
sylvanicus, meadow mouse), Arvicola oneida (=Microtus pennsylvanicus, meadow mouse), and $A$. alborufescens (=Evotomys gapperi, common red-backed mouse), prove to have been founded on insufficient characters. One species (Microtus pinetorum scalopsoides, northern pine mouse) described by Audubon and Bachman in $184 \mathrm{I}$ from specimens taken on Long Island, De Kay omits. Therefore the total number of known New York mammals in 1842 was 56 .

During the 40 years immediately following the publication of De Kay's work, the list of New York mammals received only three additions: Neotoma pennsylvanica, cave rat, recorded by Baird in 1857 under the specific name floridana, Parascalops breweri, hairy-tailed mole, recorded by Baird in 1865 under the name Scalops brezereri and Myotis subulatus, Say's bat, recorded by $H$. Allen in $186_{3}$, and for the first time distinguished from $M$. lucifugus, little brown bat (=the Vespertilio subulatus of De Kay). It is possible that the supposed occurrence of the opossum was confirmed during this period; but I have been urable to determine when the first definite record of this animal as an inhabitant of New York was published. Most of the eliminations to which I have referred were, however, made during this period by Baird, Coues and J. A. Allen. From 1842 to 1882 there appeared no important paper dealing specially with the mammals of New York, a clear indication that the stability of the list during this time resulted from lack of interest in the subject rather than from fulness of knowledge.

After De Kay, the first writer to deal extensively with the mammals of New York was Dr C. Hart Merriam, who issued two volumes on the mammals of the Adirondack region in 1882 and 1884 . At about the same time he published several short special papers which, together with the volumes just mentioned, give the results of ${ }_{5} 5$ years' field work in northern New York. It is not surprising therefore to find recorded in this short period as many additions to the mammalian fauna of the state as were made during the preceding 40 years. The species added to the New York list by Merriam at this time are: Sciuropterus sabrinus macrotis, ${ }^{1}$ Canadian flying squirrel (' $84 \mathrm{~d}$, p. 108) Sorex fumeus, ${ }^{2}$ smoky shrew ('84d, p. 77), and Tamias striatus lysteri, northeastern chipmunk ('86, p. 242). This number appears small in view of the fact that more than twice as many species have since been added to the New York list from the Adirondack region alone. It is, however, a good illustration of the futility of even the most determined efforts, unaided by the methods of collecting afterward perfected chiefly by Dr Merriam himself. 


During the past ro years the results of these improved methods have made a strong impress on the list of New York mammals. In this comparatively short period I 8 additions have been recorded, raising the total number known to have occurred in the state within historic times to $8 \mathbf{I}$. These additions, arranged chronologically, are:

Tursiops tursio (Fabricius), porpoise (True, '89, p. 34).

Delphinus delphis Linnaeus, porpoise (True, '89, p. 56, 57).

Napaozapus insignis Miller, woodland jumping-mouse (Miller, '93a, p I).

Peromyscus canadensis (Miller), Canadian white-footed mouse (Miller, '93b, p. 56).

Sorex albibarbis (Cope), water shrew (Miller,'94, p I8r).

Lepus floridanus transitionalis (Bangs), northeastern cottontail (Bangs, '95, p. 405).

Lepus floridanus mearnsi Allen, eastern prairie cottontail (Bangs, '95, p. 409).

Sorex hoyi Baird, Hoy's shrew (Merriam, '95, p. 90).

Sciurus hudsonicus loquax Bangs, southeastern red squirrel (Bangs, ' $96 d$, p. I 6 I).

Synaptomy's cooperi Baird, bog lemming (Batchelder, '96a, p. 185).

Microtus chrotorrhinus Miller, rock vole (Batchelder, '96a, p. 188).

Putorius vison lutreocephalus (Harlan), southeastern mink (Bangs, '96a, p. 4).

Sorex macrurus Batchelder, big-tailed shrew (Batchelder, '96b, p. I33).

Pipistrellus subflavus subflavus (F. Cuvier), Georgia bat (Fisher, '96 p. 1 g6).

Pipistrellus subfarus obscurus Miller, dusky bat (Miller, '97b, p. 93). Microtus nesophilus Bailey, Gull Island mouse (Bailey, '98a, p. 86; '98b, p. 783 ).

Evotomys gapperi rhoadsi Stone, New Jersey red-backed mouse (Mearns '98a, p. 333).

Synaptomys fatuus Bangs, northein bog lemming (Mearns, '98b, p. 348).

In the following table the growth of the list of New York mammals is shown in parallel columns. The names used by De Kay ('42) are given in the left hand column, ${ }^{1}$ those used by Merriam (' 82, ' 84 and ' 85 ) in the second, those adopted in the present paper in the third and the English names in the fourth.

1 From De Kay's list I omit the species included without definite knowledge of their occurrence in New Xork. 


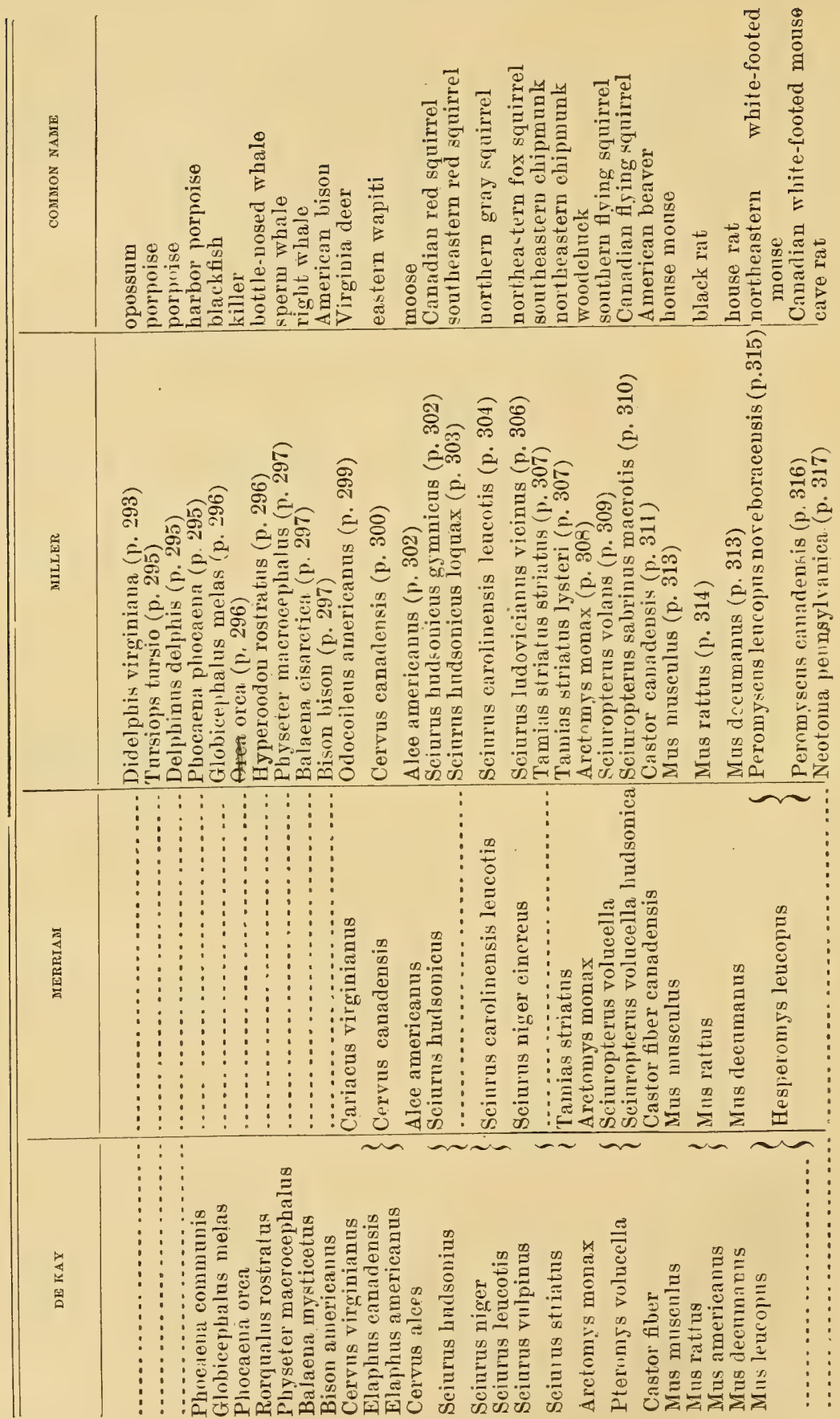








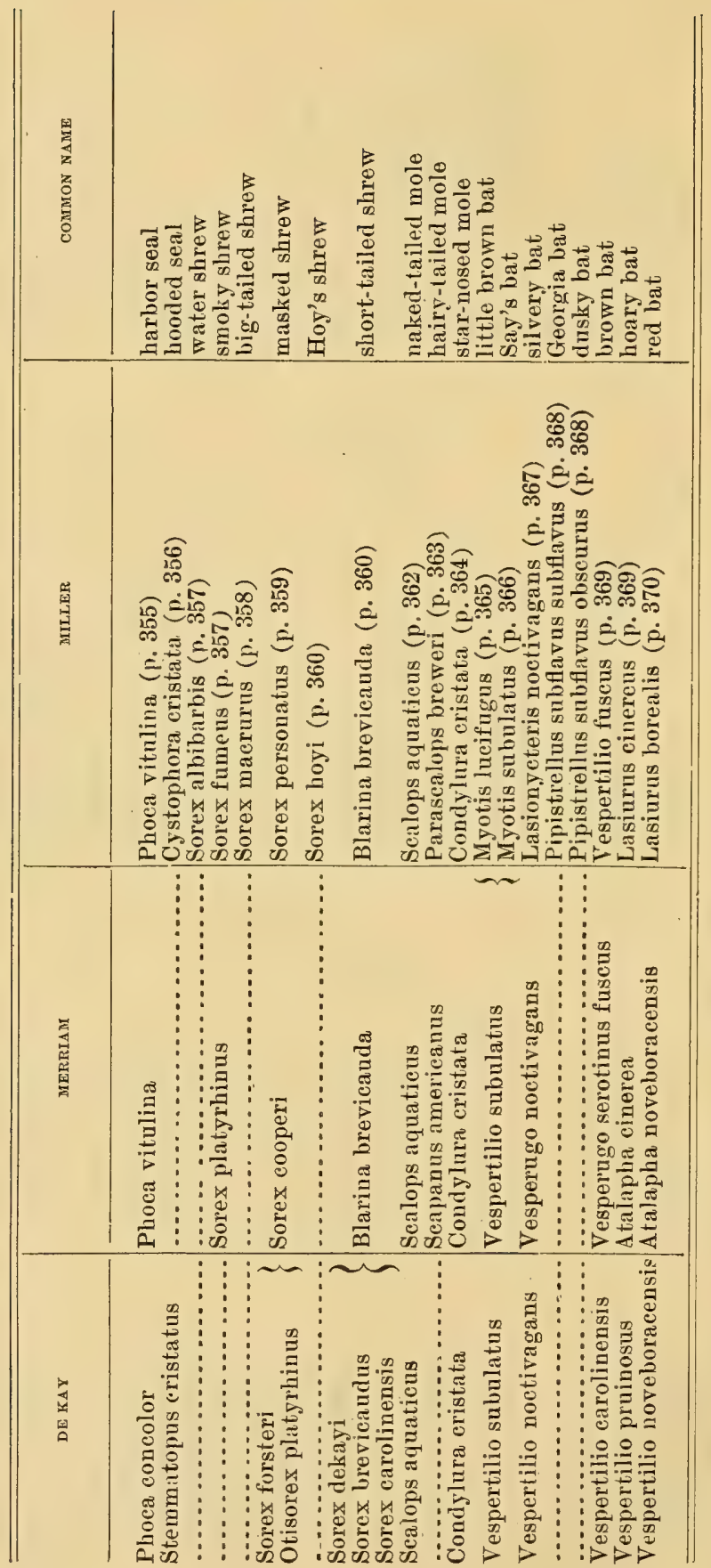



The rufa Hamition sinita fardinié Hatieralisti Lebw nol.15, 11, 189. (Hot Mil nufe Senuarevt, 1820). Hew Yorh iocyon dularis do zzz. Hew youk. 
TXPE LOCALTTIES IN NEW YORK

Thirty one descriptions of supposed new mammals have been based on specimens from New York state. Of these 20 are now regarded as applying to previously named species, but the proper arrangement of the untenable names in synonymy so largely depends on an exact knowledge of specimens taken at the original locality ('topotypes'), that the matter assumes a special importance from the point of view of systematic zoology.

The names based on New York specimens with the localities at which the latter were taken are as follows ${ }^{1}$ :

Elaphus americanus De Kay ('42, p. I20) Near mouth of Raquette river.

Elephas americanus De Kay ('42, p. IоI) Ten miles east of Rochester.

Sciuropłerus sabrinus macrotis Mearns (' 98 b, p. 353) Hunter mountain (Catskills).

Mus americanus De Kay ('42, p. 81) Rockland co.

Mus agrarius americanus Kerr ('92, p. 23r) New York state.

Mus sylvaticus noveboracensis Fischer ('29, p. 318) New York state.

Sitomys americanus canadensis Miller ('93 b, p. 55) Peterboro, Madison co.

Lemmus noveboracensis Rafinesque ('22, p. 3) Southern New York. Arvicoln rufescens De Kay ('42, p. 85) Low grounds near Oneida lake.

Arvicola oneida De Kay ('42, p. 88) Oneida lake.

Arvicola scalopsoides Audubon and Bachman ('4I, p. 97) Long Island.

Arvicola fulvus Audubon and Bachman ('4I, p. 295) St Lawrence co.

Microtus insularis Bailey ('98, p. 86) Great Gull Island. Lynx montanus Rafinesque (' $17, \mathrm{p} .46$ ) Catskill mountains. Felis ruffa Gueldenstaedt (' 76, p. 484) Central New York. Mustela pusilla De Kay ('42, p. 34) New York state.

Mustela fusca Bachman ('4r, p. 94) Suffolk co.

Putorius agilis Audubon and Bachman ('54, p. 184) Rockland co. Putorius noveboracensis Emmons ('40, p. 45) New York state. Phoca concolor De Kay ('42, p. 53) New York harbor.

Otisorex platyrhimus De Kay ('42, p. 22) Tappan, Rockland co Sorex dekayi Bachman ('37 b, p. 377) Queens co. 
Sorex fumeus Miller ('95, p. 50) Peterboro, Madison co.

Sorex macrurus Batchelder ('96 b, p. I33) Keene Heights, Essex co.

Pipistrellus subflavus obscurus Miller ('97 c, p. 93) Lake George.

Vespertilio borealis Müller ('76, p. 20) New York state.

Vespertilio gryphus F. Cuvier ('32, p. 15) Vicinity of New York city,

Vespertilio salarii F. Cuvier ('32, p. I5) Vicinity of New York city. Vespertilio crassus F. Cuvier ('32, p. 18) 'Vicinity of New York city. Vespertilio caroli Temminck ('35-4r, p. 237) Vicinity of New York city.

Atalapha fuscata Rafinesque ('20, p. 2) Northern New York.

\section{LIFE ZONES OF NEIV YORK}

The importance of an acquaintance with the life areas of a region as a key to the geographic distribution of its animals and plants is hardly to be overestimated. Indeed one of the most significant of recent developments in faunal zoology is the growing recognition of this fact. Such knowledge furnishes a ready and exact means of defining the ranges of species without the tedious enumeration of isolated localities, and offers moreover an explanation of the principal factor governing those associations of species that constitute local faunae and florae. ${ }^{1}$ Briefly defined, a life zone is a transcontinental area bounded by certain isothermal lines and characterized by relative uniformity of fauna and flora. Together with the isotherms a life zone normally extends in an approximately east and west direction, but both are subject to endless deviations. Elevations in the surface of the earth cause the life zones to bend to the southward, often many hundreds of miles beyond their normal sea-level position, while hot, dry plains have an opposite, though less, effect. Furthermore a zone is not necessarily continuous. It often happens that isolated hills and mountains reach a sufficient hight to have about their summits the climatic conditions characteristic of a more northerly zone than that at their bases. If there has ever been direct means of communication between such an isolated zonal island and the main botly of the life area to which it belongs, its fauna will more closely resemble that of the latter than that of the immediately contiguous region. ${ }^{2}$ This is however to a certain degree

1 In this connection see especially Viller, '98.

2 On mountains situated far enough south and rising to a sufficlent altitude, several successive zones will be encountered between base and summit (see Merriam, '90). 


dependent on the extent of the "island". Thus the Hudsonian area in northern New York, while large enough to support a characteristic flora, is apparently too small to be inhabited by any typical Hudsonian assemblage of mammals. Effects similar to those of elevation are produced by isolated swamps (see Bailey '96, p. 250-5 I and Batchelder, '96a, p. I92-93) and cold rock slides (see Batchelder, '96a, p. I 88 and Miller, ' 98 , p. $6 r_{5}-18$ ). The reverse condition of a southern island in a more northerly zone is less frequently met with though it occasionally occurs.

In North America seven life zones are represented. These are (beginning at the north) the Arctic, Hudsonian, Canadian, transition, upper austral, lower austral and tropical. The temperatures limiting these life areas are tabulated as follows, by Merriam ('94, p. 237, '98, p. 55). It is to be noticed that the northern limit of each zone is determined by an isotherm representing the sum of the positive temperatures for the entire season of growth and reproduction, and that the southward distribution is governed by the mean temperature of a brief period during the hottest part of the year, (Merriam, '94, p. 237, '98, p. 54 ).

\section{Governing temperatures}

\begin{tabular}{|c|c|c|c|c|}
\hline \multirow{2}{*}{ ZONES } & \multicolumn{2}{|c|}{ NORTHERN LIMIT } & \multicolumn{2}{|c|}{ SOUTHERN TIMIT } \\
\hline & \multicolumn{2}{|c|}{$\begin{array}{l}\text { Sum of normal mean } \\
\text { daily temperatures } \\
\text { above } 6^{\circ} \mathrm{c} \text {. }\left(43^{\circ} \mathrm{F} .\right)\end{array}$} & \multicolumn{2}{|c|}{$\begin{array}{l}\text { Normal mean tempera- } \\
\text { ture of six hottest } \\
\text { consecutive weeks }\end{array}$} \\
\hline Arctic & $\circ \mathrm{C}$. & $\circ \mathrm{F}$ & $\circ \mathrm{C}$ & $\therefore F$ \\
\hline 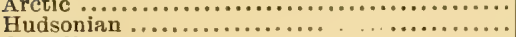 & $\ldots \ldots \ldots$ & $\ldots \ldots \ldots$ & 114 & 150 \\
\hline 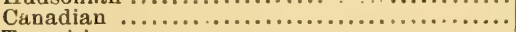 & $\ldots \ldots \ldots$ & $\ldots \ldots \ldots$ & 18 & 64.4 \\
\hline 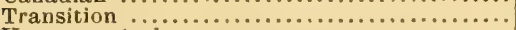 & 5500 & 10000 & 22 & 71.6 \\
\hline 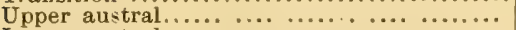 & 6400 & 11500 & 26 & 78.8 \\
\hline 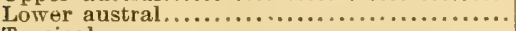 & $10(100$ & 18000 & ........... & $\ldots \ldots \ldots . . .$. \\
\hline 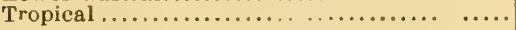 & 14500 & 26000 & ......... & $\ldots \ldots \ldots \ldots$ \\
\hline
\end{tabular}

Within the limits of New York st ite, with its north and south extent of only 260 miles, the irregularities of surface are such that no less than four life zones are represented. ${ }^{1}$ The areas that they occupy within the state are briefly as follows:

Hudsonian: Summits of the highest Adirondacks (and possibly of the Catskills also) above the region of perfect forest growth.

Canadian: Adirondack forest region, and many 'islands' on hilltops to the southward, specially in the Catskills.

1 Estimated fiom insufficient data.

2 It is probable that a fifth, the Aretic, should be recognized as occupying the treeless summits of ome of the highest Adirondack peaks. The data are at present insufficient. 
Transition: The main agricultural portion of the state

Upper austral : Hudson valley, the western part of Long Island, and the lake region.

While this is in general the distribution of the life zones in New York the details are very imperfectly known. A study of these details would be the first and most important step in a survey of the kind to which this paper is intended as a preliminary. The economic importance of such a survey in its bearing on the selection of crops for certain areas and the avoidance of crop parasites is very great. (See Howard '95, Merriam '98, and Plumb '98.)

Throughout this paper the geographic distribution of species will be stated so far as possible in terms of life zones. The salient features of the different zones however may first be considered in some detail.

Hudsonian zone. The area occupied by the Hudsonian zone in New York is too limited to support a characteristic mammalian fauna. Microtus chrotorrhinus, a typical Hudsonian mammal, probably occurs throughout the Adirondack region in favorable localities (see p. 322) in the area covered by the Canadian zone. It has also been found in the Catskills associated with Synaptomys fatuus, another Hudsonian species. At least one Hudsonian bird (Hylocichla aliciac bicknelli) breeds in the Catskills, while several such as Parus hudsonicus, Spinus pinus and Picoides americanus are found in the Adirondacks.

Among the flowering plants a number of characteristic Hudsonian forms occur on the summits of the higher Adirondacks. Peck ('80) enumerates the following species from the summit of Mt Marcy:

Solidago alpestris

Nabalus nanus

Vaccinium caespitosum

Vaccinium uliginosum

Rhododendron lapponicum

Arenaria groenlandica

Diapensia lapponica

Empetrum nigrum

Salix uva-ursi

Juncus trifidus

Scirpus caespitosus

Carex bigelovii

Poa laxa

Savastana alpina
Alpine golden-rod ${ }^{1}$

low rattlesnake-root

dwarf bilberry

great bilberry

Lapland rose bay

mountain sandwort

diapensia

black crowberry

bearberry willow

highland rush

tufted club-rush

Bigelow's sedge

wavy meadow-grass

Alpine holy grass.

1 The English names for plants are those-adopted by Britton and Brown ('96, '97 and '98). 


The period of active plant growth in this zone covers slightly less than half the year.

In a list of lepidoptera of the Adirondack region Lintner ('80) records I I species of moths (Phalcienidae) all of which occur on Mt Washington, New Hampshire, and many of which are found also in Labrador, Iceland, Lapland, the Alps of central Europe, and the high mountains of western North America. It is probable that these should be regarded as Hudsonian forms, though more strictly speaking they may be members of the Arctic fauna.

Canadian zone. In New York the characteristic mammals of the Canadian zone are:

\section{Sciurus hudsonicus gymnicus}

Sciuropterus sabrinus macrotis

Peromyscus canadensis

Evotomys gapperi gapperi

Napaeozapus insignis

Putorius vison vison

Sorex albibarbis

Sorex fumeus

Sorex macrurus ${ }^{1}$

Lasiurus cinereus
Canadian red squirrel

Canadian flying squirrel

Canadian white-footed mouse common red-backed mouse woodland jumping-mouse northern mink water shrew smoky shrew big-tailed shrew hoary bat

Many Canadian birds breed in New York, but it is necessary to mention a few of the more characteristic only. Among these are:

\section{Dendragapus canadensis}

Bonasa umbellus togata

Picoides arcticus

Empidonax flaviventris

Contopus borealis

Perisoreus canadensis

Loxia leucoptera

Zonotrichia albicollis

Junco hyemalis

Vireo philadelphicus

Dendroica maculosa

Dendroica coronata

Dendroica blackburniae

Anorthura hiemalis

Regulus satrapa

Hylocichla ustulata swainsoni
Canada grouse "

northern ruffed grouse

Arctic three-toed woodpecker yellow-bellied flycatcher olive-sided flycatcher Canada jay white-winged crossbill white-throated sparrow slate-colored junco Philadelphia vireo magnolia warbler myrtle warbler Blackburnian warbler winter wren golden-crowned kinglet olive-backed thrush

1 This animal is so silghtly known that its faunal position is still doubtful. .

2 The English names for birds are those adopted by the American ornithologists union ('95). 
Plants have as yet been so little studied with regard to zonal distribution that it is impossible to give a complete list of those whose southern limit coincides with that of the Canadian zone. The following species however belong with little doubt to this category: ${ }^{1}$

Clintonia borealis

Vagnera trifolia

Unifolium canadense

Streptopus amplexifolius

Streptopus roseus

Habenaria orbiculata

Habenaria obtusata

Betula papyrifera

Alnus alnobetula

Coptis trifolia.

Actaea rubra

Actaea alba

Bicuculla canadensis

Mitella muda

Ribes prostratum

Dalibarda repens

Fragaria canadensis

Potentilla fruticosa

Sorbus americana

Ilicoides mucronata

Acer spicatum

Circaea alpina

Panax quinquefolium

Cornus canadensis

Ledum palustre

Ledum groenlandicum

Kalmia glauca

Chiogenes hispidula

Gentiana linearis

Sambucus pubens

Viburnum alnifolium

Linnaea borealis yellow clintonia

three-leaved Solomon's seal

false lily-of-the-valley

clasping-leaved twisted-stalk

sessile leaved twisted-stalk

large round-leaved orchis

small northern bog orchis

paper birch

green or mountain alder

gold-thread

red baneberry

white baneberry

squirrel corn

naked bishop's cap

fetid currant

dalibarda

northern wild strawberry

shrubby cinquefoil

American mountain ash

wild or mountain holly

mountain maple

smaller enchanter's nightshade

ginseng

low or dwarf cornel

narrowed-leaved Labrador tea

Labrador tea

pale or swamp laurel

creeping snowberry

narrow-leaved gentian

red-berried elder

hobble-bush

twin-flower

While it may be that a few of the species enumerated are not of themselves sufficient to stamp a region as Canadian, no locality outside of this zone can have a fauna and a flora in which the mammals, birds and plants of these three lists predominate. The period of plant

1 These are mostly included among the plants found on the Adirondack league club tract. (Smith '94 and '98). 


activity in the Canadian zone covers slightly more than half the year. The season is therefore too short to allow this region to assume much agricultural importance. "In favored spots particularly along the southern border white potatoes, turnips, beets and the more hardy Russian apples and cereals may be cultivated with moderate success." (Merriam '98, p. 20)

Transition zone. The transition zone, which covers the greater part of New York state, is as its name suggests a region of intergradation between the boreal and austral life areas. More strictly speaking it is an area in which the extreme southern limit of a small but considerable number of boreal species overlaps the extreme northern limit of a large number of austral species. Its fauna and flora are therefore not readily susceptible of positive characterization, specially since few species are strictly confined to its limits. It may perhaps be best recognized negatively, that is by the absence of strictly boreal and strictly austral forms of life.

In New York at least two mammals are peculiar to the transition zone. These are both races of cottontail, Lepus floridanus transitionalis in the east and L. floridanus mearnsi in the west. A race of white-footed mouse Peromyscus leucopus noveboracensis is also supposed to be confined to the transition zone, but the status of this subspecies is still open to question and it may eventually be shown that the animal is not separable from the typical upper austral form of the species. These three animals are of distinct southern affinities. At least six other austral mammals find their northern limit in the transition zone. They are:

Sciurus hudsonicus loquax

Sciuropterus volans

Microtus pinetorum scalopsoides

Putorius vison lutreocephalus

Scalops aquaticus

Vespertilio fuscus southeastern red squirrel

southern flying squirrel

northern pine mouse

southeastern mink

naked-tailed mole

brown bat

On the other hand only the three following northern species range into this zone without passing south of it. These are :

\section{Tamias striatus lysteri}

Putorius richardsoni cicognani

Parascalops breweri northeastern chipmunk

Bonaparte's weasel

hairy-tailed mole

The occurrence of this assemblage of mammals, together with the absence of the species mentioned in the lists of Canadian and upper austral species, will serve to identify any part of the transition zone in New York. 
In the bird fauna of the transition zone southern species again predominate in a ratio of more than two to one. Some of the New York birds that find their northern breeding limit in this zone but which have an extensive range to the southward are:

\section{Colinus virginianus}

Bonasa umbellus umbellus

Zenaidura macroura

Coccyzus americanus

Antrostomus vociferus

Empidonax minimus

Icterus galbula

Pipilo erythrophthalmus

Ammodramus savannarum passerinus

Ammodramus candacutus

Cyanospiza cyanea

Stelgidoptery $x$ serripennis

Lanius ludovicianus migrans

Helminthophila chrysoptera

Dendroica aestiva

Dendroica discolor

Compsothlypis americana

Cistothorus palustris

Galeoscoptes carolinensis

Harporhynchus rufiis

Hylocichla mustelina

Sialia sialis bob-white

ruffed grouse mourning dove

yellow-billed cuckoo

whip-poor-will

least flycatcher

Baltimore oriole

towhee

grasshopper sparrow

sharp-tailed sparrow

indigo bunting

rough-winged swallow

migrant shrike

golden-winged warbler

yellow warbler

prairie warbler

parula warbler

long-billed marsh wren

catbird

brown thrasher

woodthrush

bluebird

On the other hand only about a dozen of the birds that find their southern breeding limit in the transition zone of New York range widely toward the north. Some of these are :

Podilymbus podiceps

Empidonax traillii alnorum

Carpodacus purpureus

Vireo solitarius

Helminthophila rubricapilla

Dendroica caerulescens

Dendroica pennsylvanica

Parus atricapillus

Hylocichla ustulata szeainsoni

Hylocichla fuscescens pied-billed grebe

alder flycatcher

purple finch

blue-headed vireo

Nashville warbler

black-throated blue warbler

chestnut-sided warbler

chickadee

olive-backed thrush

Wilson's thrush 


The almost total absence of exact knowledge of the distribution of plants is especially apparent when an attempt is made to catalogue the more prominent species characteristic of the transition zone. While there are doubtless many species confined to this zone it is impossible with the data at hand to make any positive statement concerning them. The flora of the region occupied by the transition zone may be recognized primarily by the absence of the strictly boreal and austral forms, and secondarily by the mixture of northern and southern types of which it is composed. As in the case of the mammals and birds the austral elements predominate. The following southern flowering plants, among others, find their northern limit in some part of the transition zone:

Pontederia cordata

Trillium granaiflorum

Trillium cernunem

Lilium philadelphicum

Smilax hispida

Smilax herbacea

Gyrostachys cernua

Chamaecyparis thyoides

Juglans nigra

Ulmus fulva

Ulmus racemosa

Benzoin benzoin

Sassafras sassafras

Dianthera americana

Conopholis americana

Pentstemon hirsutus

Datura tatula

Datura stramonium

Asclepias verticillata

Asclepias tuberosa

Azalea viscosa

Nyssa aquatica

Rhexia virginica

Meibomia grandiflora

Meibonia paniculata

Crotalaria sagittalis

Polygala polygama

Polygala nuttallii pickerel-weed

large-flowered wake-robin

nodding wake-robin

red lily

hispid green-brier

carrion-flower

nodding ladies' tresses

southern white cedar

black walnut

slippery, red or moose elm

cork or rock elm

spice-bush

sassafras or ague tree

dense-flowered water willow

squaw-root

hairy beard-tongue

purple thorn-apple

Jamestown or jimson-weed

whorled milkweed

butterfly-weed

swamp pink or honeysuckle

large tupelo

meadow-beauty

pointed-leaved tick-trefoil

panicled tick-trefoil

rattle-box

racemed milkwort

Nuttall's milkwort 
Among the northern species that find their southern limit somewhere in this zone may be mentioned:

Cypripedium reginae

Cypripedium hirsutum

Cypripedium parviflorum

Arethusa bulbosa

Taxus minor

Thuja occidentalis

Tsuga canadensis

Corema conradii

Populus grandidentata

Betula lutea

Menyanthes trifoliata

Diervilla diervilla

Comarum palustre

Oxalis acetosella showy ladies' slipper

large yellow ladies' slipper

small yellow ladies' slipper

arethusa

American yew

white cedar

hemlock

Conrad's broom crowberry

large-toothed aspen

yellow birch

buckbean

bush honeysuckle

purple or marsh cinquefoil

white or true wood-sorrel

Plant life is active in this zone during two thirds of the year, and it is consequently the most northerly life area of any real agricultural importance. "Many vegetables; the sugar beet, chicory, oats and numerous varieties of plums, cherries, pears, grapes, white potatoes and cereals attain their highest perfection" (Merriam, '98, p. 20). The principal crops of the Atiantic division of the transition zone ("Alleghanian faunal area') tabulated by Merriam ( $\not \beta 8$, p. 2 I-24) are:

wheat ( 7 varieties)
barley
rye
corn (8 varieties)
sorghum
oats ( 5 varieties)
sugar beet
buckwheat
hops
white potatoes
flax

currants (I I varieties) black currants (4 varieties) apples (90 varieties) crab apples ( 16 varieties) pears ( 37 varieties) quinces cherries (3r varieties) plums (4I varieties) grapes ( $\mathrm{I} 7$ varieties) strawberries ( 13 varieties)

There can be little doubt that the area occupied by the transition zone in New York has been very materially increased by the clearing away of the forests. The process of local extension of the transition zone may be observed in any region where Canadian forests are in p cocess of clearing from the southern side. As the cool forest cover- 


ing is removed boreal species disappear, while their places are taken by austral forms. Instances of this process in New York have been cited by Miller ('93b. p. 63) and Mearns ('98b. p. 342, 345, 360). The observations of the former refer to the rapid replacement of the Canadian white footed mouse, Peromyscus canadensis, by its more southerly reiative, $P$. leucopus noveboracensis. Mearns says : "The interior region of the Catskills surrounding Kaaterskill Junction belongs, as a whole, to the Canadian, the lowest of the boreal faunae, though slightly mixed with the Alleghanian [transition] in the farming lands on the banks of Schoharie creek. There is some evidence, however, that certain mammals of the transition and upper austral zones, as the New England cottontail (Lepus sylvaticus transitionalis), deer mouse (Peromyscus leucopus), and gray fox (Urocyon cinereoargenteus), have but lately extended their ranges to this locality by following up the clearings."

The explanation of the climatic charges that induce this alteration in fauna would involve a more thorough knowledge of forest influence than is now available. Much could be done toward a solution of the problem by a thorough biologic and climatologic survey of a small Canadian area on the southern edge of the Adirondacks. After the normal conditions under which the Canadian fauna existed were well understood the area should be cleared and reduced to the condition of a brushy pasture. This would give opportunity for a duplicate set of observations after the change in fauna had taken place, and from a comparison of the two sets, important conclusions would undoubtedly be reached.

Upper austral zone. The upper austral zone enters New York in two widely separated regions, the Hudson valley, and the extreme western part of the state in the "lake region."

In addition to the southern species already mentioned as extending their ranges into the transition zone the strictly characteristic mammals of the austral zone are:

\section{Didelphis virginiana}

Tamias striatus striatus.

Peromyscus leucopus leucopus

Neotoma pennsylvanica $\bigwedge$

Lepus floridanus mallurus

Urocyon cinereoargenteus

Pipistrellus subflar'us subflavus

Pipistrellus subflavus obscurus ${ }^{1}$ opossum

southeastern chipmunk

southeastern white-footed mouse

cave rat

southeastern cottontail

gray fox

Georgia bat

dusky bat 
Characteristic birds of the upper austral zone which breed in New York are :

Corvus ossifragus

Cardinalis cardinalis

Ammodramus maritimus

Piranga rubra

Helmilherus vermivorus

Helminthophila pinus.

Seiurus motacilla

Geothlypis formosa

Icteria virens

Wilsonia mitrata

Mimus polyglottos

Thryothorus ludovicianus

Parus bicolor fish crow

cardinal

seaside sparrow

summer tanager

worm-eating warbler

blue-winged warbler

Loxisiana water-thrush

Kentucky warbler

yellow-breasted chat

Wilson's warbler

mocking bird

Carolina wren

tufted titmouse

Among the flowering plants of the upper austral zone are many characteristic species. Some of those that occur in New York are ${ }^{1}$

Pinus virginiana

Pinus echinata

Andropogon glomeratus

Commelina communis

Commelina virginica

Tradescantia virginiana

Heteranthera reniformis

Helonias bullata

Chrosperma muscaetoxicum

Muscari racemosa

Gemmingia chinensis

Listera australis

Saururus cernunus

Quercus digitata

Quercus marylandica

Quercus phellos

Broussonetia pafyrifera

Nelumbo lutea

Magnolia acuminata

Asimina triloba

Capnoides flavulum
Jersey pine

yellow pine

bushy beard.grass

Asiatic day-flower

Virginia day-flower

spiderwort

mud plantain

swamp pink

fly-poison

starch grape-hyacinth

blackberry lily

southern twayblade

lizard's tail

Spanish oak

barren oak

willow oak

paper mulberry

American lotus

cucumber-tree

North American papaw

pale corydalis 


Liquidambar styracifua

Crataegus uniflora

Stylosanthes biflora

Meibomia laevigata

Meibomia viridiflora

Lespedeza repens

Lespedeza stuvei

Galactia regularis

Galactia volubilis

Strophostyles umbellata

Ptelea trifoliata

Euphorbia ipecacuanhae

Euonymus americanus

Ascyrum stans

Lechea leggettii

Aralia spinosa

Erythraea pulchella

Asilepias variegata

Ipomoea pandurata

Cuscuta coryli

Phlox subulata

Monarda punctata

Paulownia tomentosa

Catulpa catalpa

Diodia teres

Viburnum nudum

Viburnum prunifolium

Lonicera sempervirens

Helianthus angustifolius

Centaurea calcitrapa sweet gum

divarf thorn

pencil-flower

smooth tick-trefoil

velvet-leaved tick-trefoil

creeping bush-clover

Stuve's bush-clover

milk pea

downy milk pea

pink wild bean

three-leaved hop-tree

wild ipecac

strawberry bush

St Peter's-wort

Leggett's pin-weed

Hercules' club

branching centaury

white milkweed

wild potato vine

hazel dodder

ground or moss pink

horse-mint

Paulownia

catalpa, Indian bean

rough button-weed

larger withe-rod

black haw

trumpet honeysuckle

narrow-leaved sunflower

star thistle

In the upper austral zone plant life is dormant for a very short period, two to three months only. This is in fact the lowermost zone in which a complete winter cessation of vegetable activity occurs. Agriculturally the Atlantic division of the upper austral zone is of even more importance than that of the transition zone, since in it flourish a large proportion of the important crops of the latter, while in addition many wholly absent from the more northerly zone reach their highest state of perfection. The principal crops of the Atlantic division of the upper austral zone ('Carolinian faunal area') are thus tabulated by Merriam ('88, p. $3 \mathrm{I}-36)$. 


$\begin{array}{ll}\begin{array}{l}\text { wheat (6 varieties) } \\ \text { oats (4 varieties) }\end{array} & \text { lima beans } \\ \text { barley } & \text { apples (r } 23 \text { varieties) } \\ \text { rye } & \text { crab apples (4 varieties) } \\ \text { buckwheat } & \text { pears (43 varieties) } \\ \text { corn ( } 8 \text { varieties) } & \text { quinces ( } 5 \text { varieties) } \\ \text { sorghum } & \text { plums (54 varieties) } \\ \text { sugar beet } & \text { cherries ( } 26 \text { varieties) } \\ \text { white potatoes } & \text { peaches (35 varieties) } \\ \text { tobacco } & \text { nectarines (3 varieties) } \\ \text { sweet potatoes } & \text { apricots }(2 \text { varieties) } \\ \text { hemp } & \text { raspberries } \\ \text { flax } & \text { strawberries (I } 8 \text { varieties) } \\ \text { cow-peas } & \text { grapes (30 varieties) }\end{array}$

\section{LIST OF MAMMALS}

EXPLANATION

The subject-matter relating to each species in the present list is arranged so far as possible under seven heads, as follows: synonymy, type locality, faunal position, habitat, distribution in New York, principal records and remarks.

The synonymies contain references to first use of specific name, first use of combination adopted, and to the names used by the principal writers on the mammals of the state. Occasionally references to recent monographic papers have been added.

The only heading that calls for special remark is the sixth, "principal records." In this section I have brought together the essential parts of the records given by De Kay in the first volume of the Natural history of New York ('42), by Merriam in his Mammals of the Adirondack region, northeastern New York ('82 and '84d), by Fisher in his Mammals of Sing Sing $N . Y$. ('96) and by Mearns in his Study of the vertebrate fauna of the Hudson highland's ('98a) and Notes on the mammals of the Catskill mountains ('98b). The Catskill records of Mearns are always given, but the Hudson highlands notes are generally omitted unless they contain matter supplementary to that recorded by Fisher. In this section I have included my own observations, made principally at Peterboro, Madison co. and Elizabethtown, Essex co. Finally I have added the greater part of a list of the mammals of the vicinity of Buffalo communicated in a letter under date of March $3, \mathrm{r} 898$ by James Savage, and notes on the mammals of Long Island furnished by Arthur $\mathrm{H}$. Helme of Miller Place, Suffolk co. 


Throughout this paper, except in the tables of synonymy, bibliographic references are made by what is now generally known as the "Harvard" system. On pages $375-3^{8} 5$ is given a complete list of the works referred to arranged alphabetically by authors. Under each author the separate papers are placed chronologically, each preceded by an abbreviation of the date on which it appeared. These abbreviations serve as an index. Thus for instance the reference " $J$. A. Allen ' $94 \mathrm{~b}$ " would refer to the second paper published by J. A. Allen in 1894 , the full citation of which may be found when needed.

\section{RECENT SPECIES}

\section{Didelphis virginiana Kerr Opossum}

I792 Didelphis virginiana Kerr, Animal kingdom 1 : 193 . I842 Didelphis virginiana De Kay, Zoology of New York, Mammalia p. 4 .

I896 Didelphis virginiana Fisher, The Observer. May ı896, 7 : I94.

I 898 Didelphis virginiana Mearns, Am. mus. nat. hist. Bul. 9 Sep. r898, Io: 330 .

I898 Didelphis virginiana Mearns, U. S. Nat. mus. Proc. 2 I :36o.

Type locality. Virginia.

Faunal position. The opossum is strictly an inhabitant of the austral zones.

Habitat. Woods, thickets and old fields.

Distribution in New York. Lower Hudson valley, Long Island and the lake region.

Principal records. De Kay, "Although it is abundant in New Jersey, I have never seen it in this state, but have heard that it has been noticed in the southern counties on the west side of the River Hudson, and it will probably be found in the western counties" (" 42 p. 4).

Fisher, "Strictly speaking this animal should not be included in the present list [of the mammals found at Sing Sing, Westchester co.] because as far as known it has never been taken in Westchester county. Nevertheless it is tolerably common in Rockland and Orange counties two or three miles to the westward, and is only prevented from entering our domain by that ideal but insuperable barrier, the Hudson river. This broad, deep, powerful stream so dreaded by the old Dutch sailors of New Amsterdam, seems likewise to be feared and avoided by the equally slow-going opossum" ('96 p. r94).

Mearns: "In the [Hudson] highlands the opossum has always been fairly common since my boyhood, and hence long before its too 'suc- 
cessful' introdụction on Long Island, New York" ('98a, p. 330). "The opossum seems to be unknown in this portion of the Catskills [neighborhood of Schoharie valley] though it has been taken near the town of Catskill at the base of the mountains on the Hudson river side" ('98b, p. 360).

The animal has also been recorded from Crown Point, Essex co. (Fisher, '85a, p. I84), Rochester, Genesee co. (Lucas, '82 p. 7), Weedsport, Cayuga co. (Morehouse, '83 p. 467), Woodside, Long Island (Bragaw, '8 3 p. 467), Oakdale, Long Island (Fraser, '89 p. 212 ), Elmira, Chemung co. and Owego, Tioga co. (Loring, '99 p. 7r). Hill ('82 p. 403) notes the escape from captivity of $I 2$ individuals at Ithaca, Tompkins co, in 1878 or thereabouts.

Personally I have never met with the opossum in New York.

Mr Savage informs me of its occasional occurrence near Buffalo. That the animal is rare in the region is shown by the local interest its occasional capture arouses. Under date of April 15, 1899, Mr Sarage writes: "Two 'possum records have been made within the last six months. One was taken alive at Mill Grove, Erie county, and came into the possession of County Clerk Wende, who is quoted in the newspapers as saying that it is the first opossum ever taken in New York state. The second was taken at Hamburg by Mr Edward Colvin of that place, and is reported in the Buffalo express of Feb. 19, 1899 . It is said of this specimen that "it is the first animal of the specie (sic) shot in this vicinity in 25 years." "

Mr Helme says, "About 20 years ago reports began to accumulate of the capture of opossums in various parts of Long Island. In a few years the animal became very common and generally distributed".

Remarks. I have been unable to find the first authentic record of the opossum in New York. De Kay knew the animal as an inhabitant of the state by hearsay only. Audubon and Bachman remark, "We have no doubt that it will in time be found existing to the east of the Hudson in the southern counties of New-York as well as on Long-Island . . a as the living animals are constantly carried there... It has been stated to us that in New-Jersey within 5 or 10 miles of New-York, as many as io or 14 of these animals have ... been taken " (' 5 x p. I24). Baird in $185^{8}$ did not include New York in the animal's range (' $5^{8} \mathrm{p}$. 232-33). In recent years however the records are frequent and positive, establishing the opossum on a firm basis among the austral animals that enter the state at its southern and western extremities. It is highly 


probable that this species is one of those whose range in New York has been considerably extended within historic times.

\section{Tursiops tursio (Fabricius) Forpoise}

I780 Delphinus tursio Fabricius, Fauna Groenland p. 49.

1864 Tursiops tursio Gervais, Comptes rend. p. 876 .

I889 Tursiops tursio True, U. S. Nat. mus. Bul. 36, p. 32, I 58 .

Type locality. Coast of Greenland.

Distribution in New York. This species probably occurs commonly on both coasts of Long Island.

Principal records. True records specimens from Fire Island and Turkey Gut.

\section{Delphinus delphis Linnaeus Porpoise}

I $75^{8}$ Delphinus delphis Linnaeus, Syst. nat., ed. ro, 77 .

r842 Delphinus delphis DeKay, Zoology of New York, Mammalia p. ${ }_{3} 6$.

I888 Delphinus delphis True, U. S. Nat. mus. Bul. 36, p. 45, I60.

Type locality. Coast of Europe.

Distribution in Neze York. The sea porpoise doubtless occurs along the entire coast of New York.

Principal records. De Kay speaks of the animal as common but records no specimens (' 42 p. ${ }^{36}$ ). It is probable that his animal was Tursiops tursio, and not the present species. True gives measurements of skulls from "New York bay" and "New York harbor" ('88 p 48).

\section{Phocaena phocaena (Linnaeus) Harbor porpoise}

I $75^{8}$ Delphinus phocaena Linnaeus, Syst. nat. ed. Io I : 77 .

I842 Phocaena communis De Kay, Zoology of New York, Mammalia p. 133 .

I888 Phocaena phocaena. Jordan, Manual of the vertebrate animals of the northern United States. ed. 5 p. $33 \mathbf{r}$.

r 888 Phocaena communis True, U. S. Nat. mus. Bul. 36, p. I 8, 179.

I896 Phocaena communis Fisher, The Observer. May i896. 7:200.

Type locality. Coast of Europe.

Distribution in New York. The harbor porpoise is the commonest cetacean of the tide waters of the state. It ascends the Hudson river as far at least as Sing Sing. 
Principal records. De Kay, "The porpoise, or porpess, is common in our rivers and bays, chiefly in the spring and summer months, where they appear in the train of the migratory Clupidae [herrings], among which they make great havoc" ('42 p. r34). Fisher, "Common in the [Hudson] river [near Sing Sing] during the summer months, occasionally coming into the shallow water of the cove" ('96 p. 200).

\section{Globicephalus melas (Traill) Blackfish}

1809 Delphinus melas Traill, Nicholson's journal, 22:8r. 1842 Globicephalus melas De Kay, Zoology of New York, Mammalia p. 132.

r888 Globicephalus melas True, U. S. Nat. mus. Bul. 36, p. 133, 183.

Type locality. Coast of England.

Distribution in New York. While the eastern end of Long Island is the only locality in New York from which I have been able to find a positive record of the blackfish, the animal probably occurs occasionally on all parts of the coastline of the state.

Principal records. De Kay, "In 1834 , I received an account of the capture of two others [blackfish] on the east end of Long Island. The details furnished on that occasion enabled me to refer them with exact. ness to this species" ('42 p. I33).

\section{Orca orca (Linnaeus) Killer}

1758 Delphimus orca Linnaeus, Systema naturae ed. Iо, I : 77 .

I842 Phocuena orca De Kay, Zoology of New York, Mammalia p. I35. I888 Orca orca Jordan, Manual of the vertebrate animals of the northern United States. ed. 5, p. 33I.

I888 Orca gladiator True, U. S. Nat. mus. Bul. 36, p. I87.

Arpe locality. Coast of Europe.

Distribution in Neze York. The killer has been found on the coast of Long Island.

Principal records. . De Kay, "I have seen them off the coast of Long Island, on several occasions" ('42 p. I35).

\section{Hyperoodon rostratus (Chemnitz). Botlle-nosed whale}

I779 Balaena rostrata Chemnitz, Beschäft. der Berïin Gesell. Naturf. Freunde. $4: 183$.

I84 I Hyperoodon rostratus Wesmall, Nouv. mem. acad. roy. Belg. I3: I-13.

$\mathbf{1 8 4 2}$ Rorqualus rostratus De Kay, Zoology of New York, Mammalia. p. I30. 


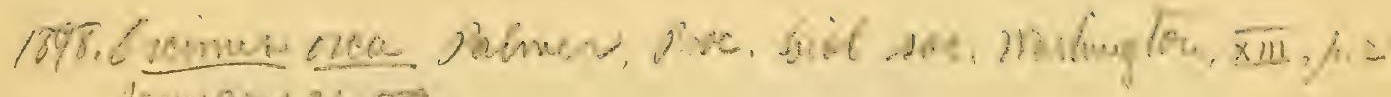
pasmary 36.189 


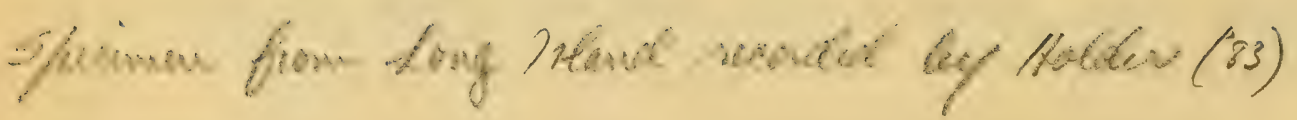


Type locality. Spitzbergen.

Distribution in New York. This whale has been taken in New York waters only once, in 1822 .

Principal records. De Kay, "The above discription was taken from a whale captured in the lower bay of New York in 1822. I had no opportunity of determining its sex, but was informed that it was a female" ('42 p. I3I).

\section{Physeter macrocephalus Linnaeus Sperm whale}

r758 Physeter macrocephalus Linnaeus, Systema naturae. ed. Io. I:75. 1842 Physeter macrocephalus De Kay, Zoology of New York, Mammalia. p. I 28.

Type locality. North Atlantic.

Distribution in New York. Formerly abundant along the coast but now nearly exterminated.

Principal records. De Kay: "The sperm whale was formerly numerous on our coast where it is still occasionally captured" ('42, p. 129).

\section{Balaena cisarctica Cope Right whale}

I842 Balaena mysticetus De Kay, Zoology of New York, Mammalia. p. I 24. Not Balaena mysticetus Linnaeus. I86 5 Balaena cisarctica Cope, Acad. nat. sci. Phila. Proc. I 7 : r69.

Type locality. "One [specimen] taken opposite this city [Philadelphia, $\mathrm{Pa}$.] three years ago, one cast ashore at Rehoboth bay, Del., and one in Mobjack bay, Va." (Cope '65 p. ז68).

Distribution in New York. Off the south coast of Long Island.

Principal records. De Kay: "Along the southern coast of Long Island, whale boats are still kept in readiness, and on the appearance of a whale the people in the vicinity quickly assemble, and are soon in pursuit of the animal" ('42 p. I25). Cope: "Some are known to enter New York harbor" ('65, p. x68).

Mr Helme writes that "the right whale is frequently seen off the south coast of Long Island in winter, and occasionally one is captured near the eastern end of the island."

\section{Bison bison (Linnaeus) American bison}

I $75^{8}$ Bos bison Linnaeus, Systema naturae. ed. Iо. I : I 72.

I842 Bison americanus De Kay, Zoology of New York, Mammalia. p. Iro.

1888 Bison bison. Jordan, Manual of the vertebrate animals of the northern United States. ed. 5. p. 337. 
Type locality. Texas.

Faunal position. Boreal, transition and austral zones.

Habitat. Plains, prairies and forests.

Distribution in New York. The bison, exterminated in this state before the beginning of the present century, probably occurred throughout western New York, east at least as far as Syracuse.

Principal records. De Kay, "The bison, or American buffalo, has been long extirpated from this state; and although it is not at present found east of the Mississippi, yet there is abundant testimony from various writers to show that this animal was formerly numerous along the Atlantic coast from New York to Mexico" ('42, p. I Io).

Allen, "The occurrence of a stream in western New York called Buffalo creek which empties into the eastern end of Lake Erie, is commonly vieived as traditional evidence of its occurrence at this point, but positive testimony to this effect has thus far escaped me. This locality, if it [the bison] actually came so far eastward, must have formed the eastern limit of its range along the lakes. I have found only highly questionable allusions to the occurrence of buffaloes along the southern shore of Lake Ontario. Keating, on the authority of Calhoun, however, has cited a passage from Morton's 'New English Canaan' as proof of their former existence in the neighborhood of this lake. Morton's statement is based on Indian reports, and the context gives sufficient evidence of the general vagueness of his knowledge of the region of which he was speaking . . The extreme northeastern limit of the former range of the buffalo seems to have been as above stated in western New York, near the eastern end of Lake Erie. That it probably ranged thus far, there is fair evidence" (' 76, p. 107).

Hornaday. In his paper on the extermination of the American bison ('89, p. 385-86) Mr Hornaday repeats Dr Allen's statements concerning the former range of the bison in New York, but is able to add no further information. Under date of January i2, $\mathbf{1} 898$, he writes me, "Since the publication of this memoir I have obtained what I consider perfectly reliable evidence that bison herds formerly visited the salt akes in the vicinity of Syracuse, and you are at liberty to mention the fact if you choose. I have not yet published the details, but intend to do so soon."

In reply to my inquiry concerning the former status of the bison in western New York, Hon. David F. Day of Buffalo replied as follows, "As to the occurrence of the bison in this state I can only say that, so far as my reading extends, the animal is not mentioned as an inhabitant 


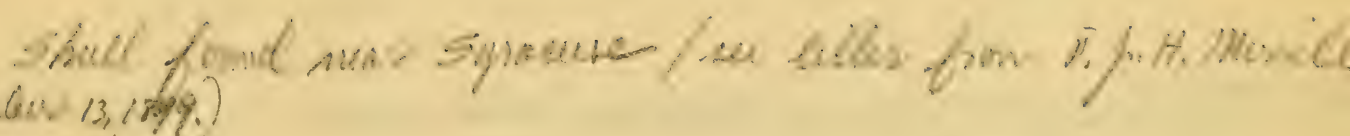


of cur territory. Still I am persuaded that it was occasionally here. It is true that it did not like either the forest or the mountains. But still I think that it might have migrated from Ohio and entered this state through the narrow strip of level land in Chautauqua county, along the shore of Lake Erie, and thus have avoided the higher grounds and the foothills of the Alleghanies. I think it would have found food sufficient for its wants in several of the western counties of New York where flat lands occur. This would harmonize with the fact that on an early French map of western New York, a stream discharging into Lake Erie is laid down, to which the name "Rivière des boeufs" was given. The Indian name of this stream has never come to my knowledge. The name of this city and of the creek where its settlement began gives no evidence of the existence of the bison in this vicinity. The city was named after the creek and the creek after an old Indian named Buffalo who lived near its mouth."

Mr Savage writes, "In regard to the bison and the naming of our city, Buffalo certainly got its name from Buffalo creek, but the origin of the name of the creek is still a mooted question. Some contend that it came from an Indian named Buffalo (but where did he get his name?) who lived on the banks of the creek. Other streams near here were named in this way, as for instance Smokes creek and Scajaquada creek. The latter flows through our principal park, and the Indian for whom it is named was formerly a well known character. I think that the persons who investigated the matter about 20 years ago failed to find in the writings of the early travellers through this region any record of the bison having been seen in New York. The Seneca Indians are said to have had a tradition that the bison formerly visited a salt lick on Buffalo creek. About two months ago I was discussing the matter with the Hon. David F. Day, who suggested that perhaps the only way to settle the question would be to dig over the site of the supposed lick in search of bones. There is evidence that the bison formerly paid summer visits to licks in western Pennsylvania and eastern Ohio, but it is probable that they came into our state as straggling, transient visitors only."

\section{Odocoileus americanus (Exxleben) Virginia deer}

I777 [Cervus dama] americanus Erxleben, Syst. regn. anim. $3^{12}$.

r842 Cervus virginianus De Kay, Zoology of New York, Mammalia. p. I I3. I884 Cariacus virginianus Merriam, Linn. soc. New York. Trans. 2 : 9. 1896 Cariacus americanus Fisher, The Observer, May ı 896, 7: 198.

I 898 Dorcclaphus virginianus Mearns, Am. mus. nat. hist. Bul. 9 Sep. I 898 , Io : 345 . 
Type locality. Southeastern Virginia.

Faunal position. The common deer of the northeastern United States is an inhabitant of the transition zone and lowest (Canadian) division of the boreal zone. The status-of the deer-of the upper-austrat-zone is not thoroughly understood.

Habitat. Forests.

Distribution in New York. Deer occur abundantly throughout the extensive forests of northern New York.

Principal records. DeKay: "This well known animal is still found in almost every part of the state where there is sufficient forest to afford them food and cover" ('42, p. II 4 ).

Merriam: "Deer are at present so abundant in most parts of the $\Lambda$ dirondacks that they outnumber all the other large mammals together. .... And there is every reason to believe that if proper game laws are enforced their numbers will not materially decrease" ('84d, p. 9).

Fisher: "The last deer killed near Sing Sing was a doe shot by $\mathrm{Mr}$ Charles Acher on December 10, 186r... In a letter from my lamented friend George Ayles dated July I, I889, after describing a fishing trip made a few days previously to Colabaugh pond a small body of water five miles north of Sing Sing, he says, 'At the place where we put up near the pond the farmer told me that he had seen a fine deer feeding in the meadow near his house that morning' ... I never heard that this deer was killed ... " ('96, p. 198). Mearns: "The Middletozen journal, issue of January 13,1878 , contains a notice of the capture of a deer near Middletown in Orange county New York. This record brings the species within the limits of the Hudson highlands, and is the only authentic one that I know of, but I am informed that deer are still occasionally found in the extreme northwest corner of Orange county" ('98a, p. 345-46).

Of the present distribution of deer on Long Island Mr Helme writes: "This animal was formerly common throughout the island, but is now restricted to an area containing about 25 square miles in the townships of Islip and Brook Haven. Here they are still plentiful thanks to the protection afforded them by the game preserves of the "South Side gun club' and a few private estates."

\section{Cervus canadensis (Erxleben) Eastern wapiti}

I 777 [Cervus elaphus] canadensis Erxleben, Syst. regn. anim. p. 305. 1842 Elaphus canadensis De Kay, Zoology of New York, Mammalia. p. II8. 


I842 Elaphus americanus De Kay, Zuology of New York, Mammalia. p. $\mathrm{x} 20$.

I884 Cervus canadensis Merriam, Linn. soc. New York. Trans. 2:45.

Type locality. Eastern Canada.

Faunal position. Boreal and transition zones.

Habitat. Forests.

Distribution in New York. While the eastern wapiti formerly occurred throughout the state it has been extinct since the early part of the present century. In Pennsylvania the animal was not exterminated till within the past 40 years (Rhoads, ' $97 \mathrm{c}$, p. 207-8).

Principal records. De Kay: "The stag is still found in the state of $\mathrm{New}$-York but very sparingly and will doubtless be extirpated before many years. Mr Beach, an intelligent hunter on the Raquet, assured me that in 1836 he shot at a stag (or as he called it an elk) on the north branch of the Saranac. He had seen many of the horns, and describes this one as much larger than the biggest buck (C: virginianus), with immense long and rounded horns, with many short antlers. His account was confirmed by another hunter, Vaughan, who killed a stag at nearly the same place. They are found in the northwestern counties of Pennsylvania and the adjoining counties of New-York. In 1834 , I am informed by Mr Philip Church, a stag was killed at Bolivar, Allegany co. My informant saw the animal and his description corresponds exactly with this species" ('42, p. I I9). "In the cabinet of the Lyceum of natural history, New York, is a portion of a pair of horns attached to a fragment of skull, dug up near the mouth of the Raquet river in this state ... A horn of the second year's growth was thrown out by a plough on Grand Isle [Lake Champlain] ". ('42, p. I20-2I).

Merriam quotes De Kay and adds, "I do not regard the above account of Messrs Beach and Vaughan as trustworthy for the reason that I have never been able to find a hunter in this wilderness, however aged, who had ever heard of a living elk in the Adirondacks. That the American elk . . . was at one time common in the Adirondacks there is no question. A number of their antlers have been discovered, the most perfect of which that I have seen is in the possession of Mr John Constable. It was found in a bog on Third lake of Fulton Chain in Herkimer co. Dr C. C. Benton, of Ogdensburg, has several specimens.... These specimens were discovered at Steele's Corners in St. Lawrence county. Mr Calvin V. Graves, of Boonville, N. Y. has two sections of elk horns that were "ploughed up in an old beaver meadow in Diana,' Lewis co." ('84d, p. 45-47). 
Under date of September 5, I898, Dr Fred F. Drury, of Gouverneur, St Lawrence co., writes to Dr Frederick J. H. Merrill as tollows: "I have recently come into possession of a pair of elk horns, dug up on a farm about four miles from this village. They were accidentally discovered while digging out a spring hole in a pasture to provide water for cattle during the dry season. One horn is in perfect state of preservation, the other has been influenced somewhat by exposure, but not enough to in any way destroy the symmetry. The perfect one measures from root to tip 39 inches, and biggest circumference $8 \frac{1}{4}$ inches. They each have five prongs, and when placed in approximate apposition have at widest point a spread of 34 inches opposite biggest prong."

\section{Alce americanus Jardine Moose}

I835 Alces americanus Jardine, Naturalists lib̧rary, x3 (Mammalia: deer, antelopes, camels, etc.) I 25

1842 Cervus alces De Kay, Zoology of New York, Mammalia. p. II 5 . I884 Alce americanus Merriam, Linn. soc. New York. Trans. $2: 40$.

Type locality. Eastern Canada.

Funulal position. Canadian and transition zone.

Distribution in Newe York. The moose which once ranged throughout the state has been extinct in New York since the early sixties.

Principal records. De Kay:- "They are yet numerous in the unsettled portions of the state, in the counties of Essex, Herkimer, Hamilton, Franklin, Lewis and Warren, and since the gradual removal of the Indians they are now (I84I) believed to be on the increase " ('42, p. I17).

Merriam: "It is not many years since the moose (Alce americanus) was a favorite object of pursuit in the Adirondacks, from which region it was exterminated as nearly as I can ascertain about the year I86I" ('84d, p. 40).

\section{Sciurus hudsonicus gymnicus Bangs Canadian red squirrel}

I842 Sciurus hudsonicus De Kay, Zoology of New York, Mammalia. p. 6I (part).

I884 Sciurus hudsonicus Merriam, Linn. soc. New York. Trans. 2: Ir I. I894 Sciurus hudsonicus J. A. Allen, Am. mus. nat. hist. Bul. 7 Nov. I894. 6:325.

I899 Sciurus hudsonicus gymnicus Bangs, New England zool. club. Proc. I : 27. 3I Mar. I899.

Type locality. Greenville (near Moosehead lake), Maine.

Faunal position. Canadian zone. 


Habitat. This animal prefers the shelter of heavy coniferous forests. It is however by no means confined to the woods, as it wanders freely wherever attracted by congenial shelter and food supply.

Distribution in New York. The details of the distribution of the Canadian form of Sciurus hudsonicus in New York are quite unknown. The animal probably occurs throughout the large Canadian area in the northern part of the state, but it is impossible at present to say exactly where the transition to the southern form loquax takes place. Mr Bangs has recorded a specimen taken at Peterboro, Madison county, as an intermediate between the two subspecies ('96d, p. I60).

Principal records. De Kay: "This familiar and well known species is found from the arctic circle to the mountainous ranges of North Carolina and Tennessee" ('42, p. 62). Merriam: "The red squirrel is one of the commonest and best known of the mammalian inhabitants of the Adirondacks, being found in all parts of the wilderness at all seasons of the year" ('84d, p. I I $\mathbf{r}$ ).

Remarks. As I have already stated the limits of the range of this form of Sciurus hudsonicus in New York are very imperfectly known. The northern and southern races have been only very recently recognized, and the details of their ranges are yet to be worked out. De Kay clearly included both forms under the name Sciurus hudsonicus, but Merriam refers exclusively to the more northern subspecies.

Scirurus hudsonicus loquax Bangs Southeastern red squirrel I842 Sciurus hudsonicus De Kay, Zoology of New York, Mammalia. p. 6r (part).

1896 Sciumus hudsonicus Fisher, The Observer. May 1896. 7:197. r896 Sciurus hudsonicus loquax Bangs, Biolog. soc. Washington. Proc. 28 Dec. г 896 . го: г6 г.

r 898 Sciurus hudsonicus loquax Mearns, Am. mus. nat. hist. Bul. 9 Sep. I898. Iо : 339 .

1898. Sciurus hudsonicus loquax Mearns, U. S. Nat. mus. Proc. 2 I : $35^{2}$.

Type locality. Liberty Hill, New London co., Connecticut.

Faunal position. Transition zone and northern edge of upper austral zone.

Habitat. "Mixed woods, groves and in fact almost everywhere; perhaps most numerous where there are large tracts of Pinus rigida, the seeds of which it is very fond of" (Bangs, '96e, p. I6 I).

Distribution in New York. The details of distribution of the southeastern red squirrel in New York are as little known as those of the range of the Canadian subspecies. The animal undoubtedly occurs throughout 
the region occupied by the transition zone and upper austral zone. This is probably one of the animals whose range has been extended by the clearing away of the heavy forests.

Principal records. De Kay: The quotation from this author cited under S. hudsonicus gymnicus refers without doubt in great part to the present form.

Fisher: "Common (at Sing Sing)" ('96, p. 197).

Mearns: "This lively inhabitant of the forest was found at all altitudes, its range extending from sea level to the highest peaks of the Catskills" ('98 p. $35^{2}$ ).

I have never met with typical Sciurus hudsonicus loquax in New York. Specimens which I took at Peterboro, Madison co., have been identified by $\mathrm{Mr}$ Outram Bangs as intermediates between this form and true hudsonicus.

Mr Savage writes, "The red squirrel is found in almost every piece of woodland near Buffalo. I have recently learned of a curious albino family of these animals that seems worthy of record. Mr Henry Urban (grocer, cor. Oak and Genesee st.) has a beautiful albino that has been in his possession since I888. He says that in that year Mr John Bergtold of Bowmansville, Erie co. captured an adult female and three young, all of which he kept alive. The adult and two of the young were perfect albinos, the other young one was normal in color. Mr Urban saw the family when alive and asked Mr Bergtold to give him any of the white animals that might die. Soon afterward he received the specimen that he now has."

Mr Helme states that the red squirrel is not found on Long Island.

Sciurus carolinensis leucotis (Gapper) Northern gray squirrel I830 Sciurus leucotis Gapper, Zool. journ. 5: 206. I842 Sciurus niger De Kay, Zoology of New York, Mammalia. p. 90 (part).

I8+2 Sciurus leucotis De Kay, Zoology of New York, Mammalia. p. 57 (part).

1877 Sciurus carolinensis var. leucotis Allen, Monogr. N. Am. Rodentia. p. 701 .

I884 Sciurus carolinensis leucotis Merriam, Linn. soc. New York.

Trans 2: $\mathbf{2} \mathbf{2}$.

1 896 Sciurus carolinensis leucotis Fisher, The Observer. $7: 197$.

1898 Sciurus carolinensis leucotis Mearns, Am. mus. nat. hist. Bul. 9 Sept. 1898. 10: 340 .

I898 Sciurus carolinensis leucotis Mearns, U. S. Nat. mus. Proc. 2 I : 353 . 


Type locality. Region between York and Lake Simcoe, Ontario, Canada.

Faunal position. Transition zone and lowermost part of Canadian zone.

Habitat. "Hardwood forests and groves of oak, chestnut and hickory" (Bangs, '96e, p. r55). The gray squirrel is often abundant in parks, cemeteries and the outskirts of towns and cities.

Distribution in Neze York. The distribution of the gray squirrel in New York is remarkably irregular. The animal is often abundant in localities where it would not be expected to thrive, and as unaccountably absent from others The cause of this irregularity is probably to be found in some variation in the food supply. That food has a very marked influence on the periodical increase and decrease of gray squirrels is well known. Dr Merriam writes, "This species . . . varies in abundance from year to year according to the conditions of the nut crop. ... My notes show that the beechnut crop was good in the autumns of I $87 \mathrm{r}, \mathrm{I} 873, \mathrm{r} 875, \mathrm{x} 877, \mathrm{r} 879, \mathrm{r} 88 \mathrm{r}, \mathrm{r} 88_{3}-\mathrm{always}$ on the odd years -while on the alternate seasons it failed. And strange as it may at first sight appear, squirrels are usually most numerous during the summer and early autumn of those years when there are few or no nuts. The reason is this: when the yield is large there is a noticeable influx of squirrels from distant parts, and they, together with those that were here at the time, winter well having an abundance of food, and breed here the following spring. During the summer and early autumn a multitude of young now nearly full grown mingle with the parent stock. Hence the species attains at this time its maximum in numbers. But this is the year when the nut crop is a failure. Therefore, as the fall advances and they find there is a scarcity of provision for the winter many of them migrate, we know not where. Then come the October "squirrel hunts"-a disgrace to the state as well as to the thoughtless men and boys who participate in them-and the number left to winter is deplorably small.

"As the abundance of the gray squirrel in winter is governed by the supply of beechnuts so is the presence at this season of its assailant, the red-headed woodpecker (Melanerpes erythrocephalus) determined by the same cause. I have elsewhere called attention to this fact, remarking that "with us a squirrel year is synonymous with a good year for Melanerpes, and vice versa' ['8rb, p. 347]. Gray squirrels, red-headed woodpeckers and beechnuts were numerous during the winters of $187 \mathrm{I}-72$, $1873-74,1875-76,1877-78,1879-80,1881-82,1883-84$ while during the alternate years the squirrels and nuts were scarce, and the woodpeckers altogether absent." ('84d, p. 127-28). 
Principal records. De Kay: "This well known little animal is found in every forest abounding in nuts of various kinds" ('42, p. 58). Merriam: This record has been quoted in sufficient detail. Fisher: "Periodically common. Some years hundreds are killed during the open season, while on the following year not over a dozen will be secured" ( 96 , p. 197). Mearns: "The gray squirrel is rare in this region [the Catskills]; but one individual was seen during our stay" ('98b, p. 353).

I have found the gray squirrel rare at Peterboro, Madison co.

Remarks. In his revision of the squirrels of eastern North America Mr Outram Bangs says that the southeastern gray squirrel, Sciurus carolinensis carolinensis ranges "north about to the lower Hudson valley." There is, however, no positive evidence as yet that this form actually occurs in New York.

\section{Sciurus ludovicianus vicinus Bangs Northeastern fox squirrel}

I842 Sciurus vulpinus De Kay, Zoology of New York, Mammalia. p. 59. I 884 Sciurus niger cinereus Merriam, Linn. soc. New York. Trans. 2: I 34 . 1896 Sciurus niger cinereus Fisher, The Observer. May I896. 7: 97 • ז896 Sciurus hudovicianus vicinus Bangs, Biolog. soc. Washington. Proc. 28 Dec. 1896 , ro: 150.

Type locality. White Sulphur springs, West Virginia.

Faunal position. The northeastern fox squirrel is an inhabitant of the upper austral zone, but occasionaly it wanders into the transition zone.

Habitat. Extensive forests.

Distribution in New York. In New York the occurrence of the fox squirrel can now be regarded as little more than accidental. Formerly however it was found in considerable numbers.

Principal records. De Kay: "Its habits and geographic distribution are the same as in the preceding $[S$. leucotis]" ('42, p. 60). Merriam: "The fox squirrel can not at present be regarded as other than a rare or accidental straggler in the Adirondack region. So far as I am aware the only specimen taken here of late was killed by Oliver B. Lockhardt at Lake George, Warren co. in 1872 or 1873 " (' 84 d, p. 134). Fisher : "Mr Gilbert C. Merritt once informed me that he had killed several fox squirrel in the Chappaqua hills about the year $185^{\circ}$. Of late none have been heard of even in that wild region" ('96, p. 197).

$\mathrm{Mr}$ Savage writes that there is an old mounted specimen of this animal in the museum of the Buffalo Society of natural science, labeled 'Erie county.' He does not consider the record as positive however, since all definite history of the specimen is lacking.

Mr Helme informs me that the fox squirrel does not occur on Long Island. 


Tamias striatus striatus (Linnaeus) Southeastern chipmunk I758 Sciurus striatus Linnaeus, Syst. nat. ed. Io. I : I64. I842 Sciurus striatus De Kay, Zoology of New York, Mammalia. p. 62 (part).

I 857 Tamias striatus Baird, I th Smithsonian report. p. 55 (part). I886 Tamias striatus Merriam, American naturalist. Feb. I896. 20:242. 1896 Tamias striatus Fisher, The Observer. May ı896. $7:$ ig6. I898 Tamias striatus Mearns, Am. mus. nat. hist. Bul. 9 Sep. 1898 . Io: $33^{8}$.

Type locality. Virginia and Carolina.

Faunal position. Upper austral zone.

Habitat. Thickets, rocky ledges and dry, open woods.

Distribution in New York. The southeastern chipmunk reaches New York, so far as at present known, in the lower Hudson valley only. I have never seen a specimen from the upper austral area in the western part of the state, and therefore can not say positively which form occurs there.

Principal records. De Kay did not distinguish between the two forms of chipmunk now known to occur in New York, but his references to the animal show that he included both under the name Sciurus striatus ('42, p. 62). Fisher: "Common [at Sing Sing]" '96, p. I96. Mearns: "The southern chipmunk is by far the most abundant member of the squirrel family in the Highlands. It lives everywhere, from the islands of the Hudson to the highest mountain tops, though it is least common on the high ground" ('98a, p. 338).

Of the chipmunk on Long Island Mr Helme writes, "This animal is common. A few years ago it was nearly exterminated, but now it has become plentiful again. The cause of this decrease in numbers was due I believe to an extremely cold winter following an autumn in which the food supply was short."

\section{Tamias striatus lysteri (Richardson) Northeastern chipmunk} r829 Sciurus (Tamias) lysteri Richardson, Fauna Boreali-Americana. I : 182 .

I842 Sciurus striatus De Kay, Zoology of New York, Mammalia. p. 62 (part).

I884 Tamias striatus Merriam, Linn. soc. New York. Trans. 2 : I35. I886 Tamias striatus lysteri Merriam, American naturalist. Feb. I 886. $20: 242$.

I 898 Tamias striatus lysteri Mearns, U. S. Nat. mus. Proc. 2 I : $35^{2}$. 
Type locility. Penetanguishene, Georgian Bay, Ontario, Canada.

Faunal position. Transition zone and warmer, more open parts of Canadian zone.

Habitat. The habitat of the northeastern chipmunk is the same as that of its southern relative.

Distribution in Neze York. The northeastern chipmunk is very generally distributed throughout the greater part of New York state. Specimens intermediate between the two races have been taken in the lower Hudson valley by Mearns (Miller ' 97 p. 3०).

Principal records. De Kay: "It is common over all the state" ('42, p. 64). Merriam: "The chipmunk or ground squirrel is always present in greater or less numbers in some parts of the Adirondacks. It is a migratory animal and is exceedingly abundant some years, while during others it is scarcely seen at all, the difference being dependent on the quantity of the food supply" ('84d, p. 135). Mearns: "The chipmunk of the Schoharie valley is distinctly of the lysteri type. It was common but shy, occurring from the edge of the creek (altitude i 700 feet) up to the summit of Hunter mountain (altitude 4025 feet). At Palenville, on the Hudson river side of the Catskills, intermediates between the forms striatus and lysteri occur; in the Hudson highlands a few individuals from the highest elevations verge toward lysteri; and lower down the Hudson valley only true striatics is found. No difference was detected bétween specimens collected in spruce forests and balsam swamps on the mountains and those from the fields and fences along Schoharie creek" ('98, p. $\left.35^{2}\right)$.

I have found Tamias striatus lysteri abundant at Peterboro, Madison co., and at Elizabethtown, Essex co.

\section{Arctomys monax (Linnaeus) Woodchick}

$175^{8}$ Mus monax Linnaeus, Syst. nat. ed. го. I : 6 o. I 780 Arctomys monax Schreber, Säugethiere. 4: pl. 208

1842 Arctomys monax De Kay, Zoology of New York, Mammalia. p. 69. 1884 Arctomys monax Merriam, Linn. soc. New York. Trans. 2: 142. 1896 Arctomys monax Fisher, The Observer. May г896. $7: 196$.

I898 Arctomys monax Mearns, Am. mus. nat. hist. Bul. 9 Sep. 1898. Iо: $33^{8}$.

I898 Arctomys monax Mearns, U. S. Nat. mus. Proc. $2 \mathrm{I}: 35^{2}$.

Type locality. Maryland.

Faunal position. The range of the woodchuck is now supposed to extend from well within the upper austral zone through the Canadian zone. 


Habitat. Principally meadows and cleared land, but the animal is found in almost every variety of situation providing suitable ground for the construction of extensive burrows.

Distribution in New York. The woodchuck probably occurs in every county of New York. While it is probable that the range of this animal has not been materially affected by the settlement of the country, there can be little doubt that there are more woodchucks now in the state than there were before the arrival of the white settlers.

Principal records. DeKay." "The woodchuck... is common in almost every county in the state" ('42, p. 69). Merriam: "The woodchuck is rare ... within the proper limits of the Adirondacks, though he has been found sparingly in the remotest parts of the wilderness. In the cultivated area surrounding the Adirondacks he is very abundant" ('84 d, p. 142). Fisher: "Common [at Sing Sing]" ('96, p. 196). Mearns: "This species is... tolerably common in the Schoharie valley" ('98 b, p. $35^{2}$ ).

I have found the woodchuck common at Geneva, Ontario co. and Peterboro, Madison co.

Mr Savage writes, "The woodchuck is more common in the hills south and east of Buffalo than in the flat country immediately about the city. However I know of a family of 'chucks' in a bank less than three miles from my home."

Mr Helme writes that the woodchuck though common on Long Island is in certain localities less numerous than it was a few years ago. He attributes this fact to the effect of bounties offered by several townships for the animals' scalps.

Remarks. It is probable that the woodchuck of the Canadian forests is not true Arctomys monax. The material necessary to decide the question is lacking. For all account of the tree-climbing propensities of the woodchuck see Merriam '8 8 a.

\section{Sciuropterus volans (Linnaeus) Southern fying squirrel}

I $75^{8}$ Mus volans Linnaeus, Syst. nat. ed. xо. $\quad$ : $: 63$.

r842 Pteromys volucella De Kay, Zoology of New York, Mammalia. p. 66 (part).

ז884 Sciuropterus volucella Merriam, Linn. soc. New York. Trans. $2: 99$.

I890 Sciuropterus volans Jordan, Man. vertebr. anim. northeastern U. S. ed. 5. p. 324 .

1896 Sciuropterus volucella Fisher, The Observer. May 1896. 7:197. 
I896 Sciuropterus volans Bangs, Biolog. soc. Washington. Proc. 28 Dec: 1896 . Io: 164 .

1898 Sciuropterus volans Mearns, Am. mus. nat. his. Bul. 9 Sep. I898. Io: 34 I.

Type locality. Virginia.

Faunal position. The southern flying squirrel is a characteristic inhabitant of the austral zones and the transition zone. It barely reaches the lower edge of the Canadian zone in favorable localities.

Habitat. Woodlands, orchards, parks, buildings; wherever convenient shelter can be found.

Distribution in New York. The southern flying squirrel probably occurs throughout New York state except in large tracts of Canadian forest. The details of its overlapping in range with the Canadian flying squirrel remain to be worked out.

Principal records. De Kay: "The flying squirrel is well known throughout state" this ('42, p 66). Merriam: "Two varieties of flying squirrel occur in the Adirondacks : the present form, confined mainly to the borders of the region, and a northern race, commonest in the elevated portions of the interior" ('84 d, p. 99). Fisher: "Common [at Sing Sing]. In the daytime they remain quietly in hollow trees, bird houses, out buildings, hay lofts, or garrets of houses, and as dusk approaches come out of their hiding places and start off on foraging expeditions" ('96, p. 197).

I have found the southern flying squirrel at Peterboro, Madison co, though it is apparently less numerous there than the Canadian species. I have also taken it at Geneva, Ontario county.

Mr Savage writes: "The flying squirrel is seldom met with in the vicinity of Buffalo, but it is probably more common than is generally supposed. I took a pair December 8, 1897."

According to Mr Helme the flying squirrel is common on Long Island.

\section{Sciuropterus sabrinus macrotis Mearns Canadian fying squirrel}

1842 Pteromys volucella De Kay, Zoology of New York, Mammalia. p. 66 (part).

I884 Sciuropterus volucella hudsonius Merriam, Linn. soc. New York. Trans. 2: ro8. (Not Sciurus hudsonius Gmelin).

I896. Sciunopterus sabrinus, Bangs, Biolog. soc. Washington. Proc. 28 Dec. 1896. 10: 162 (part).

r898. Sciuropterus sabrinus macrotis Mearns, U. S. Nat. mus. Proc. $21: 353$. 


Type locality. Hunter mountain (Catskills) Greene co., New York.

Fanual position. Canadian zone.

Habitat. Forests.

Distribution in New York. In New York this animal is found throughout the great boreal area in the northern part of the state, and on the numerous boreal "islands" south of this region. In many localities on the border line between the transition zone and Canadian zone it is found associated with the smaller species $S$. volans but the two animals never intergrade (see Merriam ' 84 d, p.' го8, and Bangs, '96d, p. г63).

Principal records. DeKay: See last species. Merriam: "The northern flying squirrel is a common inhabitant of the elevated central area of the Adirondacks and is not particularly rare about the outskirts of the region, where I have found both varieties nesting in adjoining trees". (' $84 \mathrm{~d}$, $\mathrm{p}$. I08). Mearns: "This species was found in spruce woods on the ridge of Hunter mountain [Catskills], at the altitude of 3300 feet. Flying squirrels are said to be common everywhere in the region. One seen on August 7,1896 near the base of East Kill mountain at 5800 feet altitude may have been either the present species or Sciuropterus volans (Linnaeus)" ('98b, p. 354).

I have taken the Canadian flying squirrels at Peterboro, Madison co., and at Elizabethtown, Essex co. It is common at each locality.

Castor canadensis Kuhl American beaver

I8zo Castor canadensis Kuhl, Beitrage zur Zoologie und vergl. Anat. p. 64.

1842 Castor fiber De Kay, Zoology of New York, Mammalia. p. 72.

I884 Castor fiber canadensis Merriam, Linn. soc. New York. Trans. 2: 155 .

I898 Castor canadensis Mearns, Am. mus. nat. hist. Bul. 9 Sep. 1898 . Io: $35 \mathrm{I}$.

Type locality. Hudson bay.

Fannal position. Partly on account of the animal's aquatic habits, and partly on account of lack of definite knowledge of its geographic variations, it is impossible at present to assign the beaver a satisfactory faunal position. Beaver are known to range from the southern part of the lower austral zone in the south to the northern edge of the Hudsonian zone in the north. Surprising as it may seem. there is at present no means for determining whether more than one race occurs in this area. ${ }^{a}$

a Since this was written, Mr S. N. Rhoads has divided the beaver into two races, a boreal form, true Castor canadensis and an austral form, C. canadensis carolinensis. (Trans. Am. philos. soc., NS., September 1898 19:417-23). 
Habitat. Borders of streams, ponds and lakes.

Distribution in New York. The beaver is probably nearly exterminated if not quite extinct-in New York. Concerning the animal's status I have nothing to add to the account given by Merriam in 1884 .

Principal records. De Kay: "The beaver, whose skins once formed so important an article of commerce to this state as to have been incorporated in the armorial bearings of the old colony, is now nearly extirpated within its limits . . . In the summer of 1840 we traversed those almost interminable forests on the highlands separating the sources of the Hudson and the St Lawrence, and included in Hamilton, Herkimer and a part of Essex counties. In the course of our journey we saw several beaver signs as they are termed by the hunters. The beaver has been so much harassed in this state that it has ceased making dams, and contents itself in making large excavations in the banks of streams. Within the past year (184r) they have been seen on Indian and Cedar rivers, and at Pashungamah on Tupper's lake; and although they are not numerous, yet they are still found in scattered families in the northern part of Hamilton, the southern part of St Lawrence and the western part of Essex counties. Through the considerate attention of Mr A. McIntyre those yet existing in the southern part of Franklin co. are carefully preserved from the avidity of the hunter and there probably the last of the species in the Atlantic states will be found" ('42, p. 73-74).

Merriam: "That the beaver was once abundant in all parts of the Adirondacks is attested by the numerous remains and effects of their dams, but at present they are so exceedingly rare that few people know that they still exist here . . . During the fall of 1880 a beaver was caught on Raquette river between the Upper Saranac and Big Tupper's lake and about a mile below the 'Sweeney carry' ... Subsequent to this date saplings were cut in the neighborhood showing that another was at work there ... At present there is a small colony of beavers on a stream that empties into the west branch of the St Regis river. It is probably the colony referred to by De Kay in 1842 as 'yet existing in the southern part of Franklin co.'" (84d, p. 155-58).

Mearns: "When I was a boy the remains of a beaver-dam were plainly visible at Bog Meadow pond, in Orange co. When this pond was raised a few years ago to supply the town waterworks at Highland falls the dam was submerged, and with it disappeared the last vestige of the beaver, long extinct in the [Hudson] highlands" ('98a, p. 35 I-52). 




\section{Mus musculus Linnaeus House mouse}

I758 [Mus] musculus Linnaeus, Syst. nat. ed. го. I : 62.

r842 Mus musculus De Kay, Zoology of New York, Mammalia. p. 82.

1884 Mus musculus Merriam, Linn. soc. New York. Trans. 2 : 16z.

r896 Mus musculus Fisher, The Observer. May r 896. 7:197.

r 898 Mus musculus Mearns, Am. mus. nat. hist. Bul. 9 Sep. 1898 . IO: 3379 .

I898 Mus musculus Mearns, U. S. Nat mus. Proc. 2 I :35 I.

Type locality. Siveden.

Funnal position. The house mouse on account of its semi-domestication can not be assigned to any definite faunal position.

Habitat. Buildings, fields, and occasionally woodlands.

Distribution in New York. This animal is abundant throughout the settled part of New York. It is by no means strictly confined to buildings.

Principal records. De Kay: "This familar little species bas also been introduced from Europe into this country since its discovery. It has everywhere followed the footsteps of man ..." ('42, p. 82). Merriam: "I have observed the house mouse in many of the camps scattered through the Adirondacks and have killed it, though rarely, at a considerable distance from the habitations of man. It is common in the fertile valleys along the outskirts of the wilderness, living in the fields during the short summer season, and returning to the divellings, barns and haystacks at the approach of winter" ('84, p. I62). Fisher: "Common in the corn and rye fields as well as around buildings" ('96, p. r97). Mearns: "Common in fields and houses. Several were trapped under stacks of fodder corn standing in the fields. None were caught in the woods" ('98b, p. $35 \mathrm{I}$ ).

I have found the house mouse abundant at Geneva, Ontario co. Peterboro, Madison co, and Elizabethtown, Essex co.

Mr Savage reports it abundant at Buffalo.

Helme: "The house mouse is abundant on Long Island."

\section{Mus decumanus Pallas House rat}

I 778 Mus decumanus Pallas, Nov. Sp. Quadr. e Glir. Ord., p. 9i. I842 Mus decumanus De Kay, Zoology of New York, Mammalia. p. 79. I884 Mus decumanus Merriam, Linn. soc. New York. Trans. 2 : I6I.

1896 Mus decumanus Fisher, The Observer. May r 896. 7: 197 .

r898 Mus decumanis Mearns, Am. mus. nat. hist. Bul. 9 Sep. 1898 . I о : 336 .

I898 Mus decumanus Mearns, U. S. Nat. mus. Proc. 2 I : 35 I. 
Type locality. Russia.

Fannal position. As with the other introduced species of old world rats it is impossible to assign this animal a definite faunal position.

Habitat. Houses, outbuildings and fields.

Distribution in New York. 'The house rat occurs throughout New York, wherever there are towns or settlements.

Principal records. De Kay: "In this country it was introduced with the foreign mercenaries during the revolutionary war. They are now numerous in all the states, and have even extended to Canada" ('42, p. 80). Merriam: "This ubiquitous naturalized exotic is found even within the confines of the Adirondacks. But his presence here omens no good. Like the lumberman, whose footsteps he follows, he is the personification of destruction and desecrates the soil on which he treads" ('84d, p. I6r). Fisher: "Common [at Sing Sing]" ('86, p. 197). Mearns: "Abundant. One was trapped at the base of East Kill mountain at the altitude of 2000 feet" ('98b, p. 351).

I have found the house rat at Geneva, Ontario co.; Peterboro, Madison co. and Elizabethtown, Essex co. Mr Savage reports it abundant in the neighborhood of Buffalo, and Mr Helme reports it equally numerous on Long Island.

\section{Mus rattus Linnaeus Black rat}

I $75^{8}$ [Mus] rattus Linnaeus, Syst. nat. ed. Iо. I : 6 I.

r842 Mus rattus De Kay, Zoology of New York, Mammalia. p. 80 (part).

I842 Mus americanus De Kay, Zoology of New York, Mammalia. p. 8I (part).

Type locality. Sweden.

Faunal position. Not now determinable as the animal has been too widely distributed by artificial means.

Habitat. Houses and buildings of various kinds.

Distribution in New York. It is doubtful whether the black rat still exists in New York.

Principal records. De Kay: "It is now exceedingly rare" ('42, p. 8I). The animal is not mentioned by Merriam, Fisher or Mearns.

I have never seen the black rat in New York. Many of the older inhabitants at Peterboro, Madison co. have told me of the immense numbers in which the 'blue rats' or 'barn rats' once occurred. To judge from these accounts, which I consider trustworthy, this animal must have been more abundant than its successor the house rat. Mr Hiram Wilson 


of Oneida, Madison co. writes me, under date of February 3, I898, that he first saw the brown rat when his family moved to. Oneida valley in 1837 . Previously the Wilsons had lived near Peterboro (about I 2 miles distant), where only the black rat occurred.

\section{Peromyscus leucopus noveboracensis (Fischer) Northeastern}

white-footed mouse

I829 [Mus sylvaticus] $\Delta$ Noveboracensis. Fischer. Synopsis mammalium. p. 3 г 8 .

I830 Cricetus myoides Gapper, Zool. journ. $5: 204$.

I842 Mus leucopus De Kay, Zoology of New York, Mammalia. p. 82. I884 Hesperomys leucopus Merriam, Linn. soc. New York. Trans. $2:{ }^{6} 5$ (part).

I896 Peromyscus leucopus Fisher, The Observer. May ı896. $7:$ I97.

I897 Peromyscus leucopus myodes (sic) Rhoads, Acad. nat. sci. Philadelphia. Proc. p. 27.

I897 Peromyscus leucopus noveboracensis Miller, Boston soc. nat. hist. Proc. 30 Ap. I897. 28:22.

r898 Peromyscus leucopus Mearns, Am. mus. nat. hist. Bul. 9 Sep. I898. Io: 334 .

I 898 Peromyscus leucopus Mearns, U. S. Nat. mus. Proc. 2 I : 350.

Type locality. New York.

Faunal position. Transition zone and lowermost edge of Canadian zone.

Habitat. Dry, open woods, thickets, fields, outbuildings and occasionally houses.

Distribution in New York. The northeastern white-footed mouse occurs throughout New York state except in the boreal area occupied by the Canadian white-footed mouse, and in a few localities where the genus Peromyscus is not found. It is possible that in the lower Hudson valley this form is replaced by the southeastern white-footed mouse as implied by Rhoads ('97a, p. 27), but I am not satisfied that this is actually the case.

Principal records. De Kay: "The jumping [= white-footed] mouse is found in every part of the state, and is said to build its nest in trees" ('42, p. 83). Merriam: "The white-footed mouse is common in all parts of the Adirondacks" ('84d, p. 165). Fisher: "Common [at Sing Sing]. This mouse is found everywhere in the woods and groves about fence rows, and in fall and winter ventures to the "stacks and out-houses" ('96, p. I97-98). Mearns: "This beautiful mouse was rather abun- 
dant along Schoharie creek, especially about farms and buildings. On the right side of Schoharie creek it was found sparingly distributed around the lower third of East Kill mountain, but was nowhere abundant above the creek bottom. On the left side it was not found above 2000 feet altitude. . . In the Highlands of the Hudson P. leucopus is abundant, but in the highest parts where the black spruce and tamarack grow, no species of Peromyscus could be found. In other words where $P$. canadensis should have been found the genus was unrepresented" ('98b, p. 350).

I have taken the northeastern white-footed mouse at Geneva, Ontario co.; Peterboro, Madison co. and Elizabethtown, Essex co. At Peterboro and Elizabethtown it occurs in association with $P$. canadensis, the habitats of the two animals overlapping at the edges of forests and woodlands.

Mr Savage reports the animal common about Buffalo.

Of the white-footed mouse on Long Island Mr Helme writes: "This is an abundant species on all parts of the island. During cold weather several will often be found occupying one nest. I have taken as many as 16 at one time in a nest under a hollow log."

Peromyscus canadensis (Miller) Canadian white-footed mouse I842 Mus leucopus De Kay, Zoology of New York, Mammalia. p. 82 (part).

i 858 Hesperomys myoides Baird, Mam. N. Am. p. 472 (part). I884 Hesperomys leucopus Merriam, Linn. soc. New York. Trans. $2: \mathbf{1} 65$ (part).

1893 Sitomys americanus canadensis Miller, Biolog. soc. Washington. Proc. 20 June $1893 . \quad 7: 55$.

r896 Peromyscus canadensis Bangs, Biolog. soc. Washington. Proc. I9 Mar, 1896. I0:49.

I 898 Peromyscus canadensis Mearns, U. S. Nat. mus. Proc. $21: 35^{\circ}$.

Type locality. Peterboro, Madison co., New York.

Faunal position. Canadian zone.

Habitat. While the Canadian white-footed mouse is primarily an inhabitant of dense, damp forests it may be found in an almost endless variety of situations.

Distribution in Nere York. The Canadian white-footed mouse occurs throughout the extensive Canadian forests in the northern part of the state and in isolated colonies further south, where elevation or dense damp woodland gives it essentially Canadian environment. 


Principal records. De Kay and Merriam: The statements by these writers quoted under the northeastern white-footed mouse refer partly to the present species.

Mearns: "The Canadian deer mouse though nowhere abundant was found from the margin of Schoharie creek up to the summit of Hunter mountain and in all sorts of places-sugar camps, deserted houses, leciduous woods, spruce and balsam swamps, under rocks, among the roots of old stumps, in brush heaps, and in open grassy places; in short it was found everywhere, but nowhere in abundance. It was much less common than Peromyscus leucopus along Schoharie creek, where both species were sometimes taken in the same spot. When trapped its cheek pouches are as likely to be filled with food as those of the chipmunk. I do not remember ever to have found food in those of Peromyscus leucopus" ('98b, p. 350).

This species is abundant at Peterboro, Madison co. and Elizabethtown, Essex co., but I have not met with it elsewhere in New York. In both of these localities it is chiefly a forest mouse, seldom entering the cleared land occupied by $P$.leucopus noveboracensis. In open groves and about the outskirts of heavy woods the two species meet on neutral ground, but in general their ranges are so distinct that it is possible after a little experience to predict which animal will be caught in a particular spot. In the original description of this mouse (Miller, '93b, p. 62) I called attention to the fact, since verified by Dr Mearns, that the cheek pouches are much more freely used by this species than by the northeastern white-footed mouse.

\section{Neotoma pennsylvanica Stone Cave rat}

I858 Neotoma floridana Baird, Mam. N. Am. p. 489 (part).

I 893 Neotoma pennsylvanica Stone, Acad. nat. sci. Philadelphia. Proc. 2 I Feb. I883. p. 16.

I894 Neotoma magister Rhoads, Acad. nat. sci. Philadelphia. Proc. Oct. 1894. p. 2 I3 (not of Baird).

r894 Neotoma pennsylvanica Allen, Am. mus. nat. hist. Bul. 22 Dec. ז $894.6: 362$.

I898 Neotoma pennsylvanica Mearns, Am. mus. nat. hist. Bul. 9 Sep. I 898 . Iо : 334 .

Type locality. South mountain, Cumberland co. Pennsylvania.

Faunal position. The cave rat is probably an inhabitant of the transition zone, though its peculiar habits make any definite decision a matter of uncertainty. It occurs in many localities within the limits of 
the upper austral zone, but such places may prove to be transition 'islands.'

- Habitat. Caves, overhanging cliffs and rocky mountain sides.

Distribution in New York. The cave rat is not at present known to occur in New York outside of the lower Hudson valley, though there is reason to believe that it will be found at other localities along the southern border of the state.

Principal records. Baird: "A few specimens of unusually large size were captured some years ago by $\mathrm{Mr} \mathrm{J}$. G. Bell near Pierpont on the Hudson river" ('58, p. 489). Allen: "I have now to record the capture of a specimen on Storm King mountain, Cornwall, Orange co. N. Y. about 50 miles north of New York city and 40 miles north of Piermont. . . The place of capture was at the base of a cliff 30 or 40 feet in height at an elevation of about rooo feet. The cliff is full of deep crevices and has a talus of loose stones at its base" ('94 b, p. 362).

Remarks. With regard to the relationship of this animal with the fossil species found in the cave deposits of Pennsylvania Dr Mearns writes: "Mr Samuel N. Rhoads in a paper entitled 'A contribution to the life history of the Alleghany cave rat, Neotoma magister Baird' ['94], claims that the recent species described by Mr Witmer Stone ['93 b] under the name Neotoma pennsylvanica is specifically identical with the subfossil cave species named Neotoma magister by Baird ['57, p. 486]. I am unable to concur in this opinion, for the reason that a comparison of eight jaws - one upper and seven lowerbelonging to Baird's type series of his Neotoma magister differ in important respects from a series of recent skulls . . . of Neotoma pennsylvanica Stone. . . In this comparison Neotoma magister proves to have been a considerably larger and stouter animal than $N$. pennsylvanica, the skull is relatively shorter . . . the mandibles are deeper . . . the tooth row broader and longer . . " ('98 a, p. 334-35). I have examined the specimens referred to by Dr Mearns and see no reason to question his conclusion. Remains of Neotoma magister are to be looked for in caves and rock fissures in southern New York.

\section{Evotomys gapperi gapperi (Vigors) Common red-backed mouse}

1830 Arvicola gapperi Vigors, Zool. journ., 5: 204.

I84 I Arvicola fulvus Audubon \& Bachman, Acad. nat. sci. Philadelphia. Journ. 5 Oct. r841. v. 7. pt. $2: 295$.

1842 Arvicola rufesicens De Kay, Zoology of New York, Mammalia. p. 85 . 


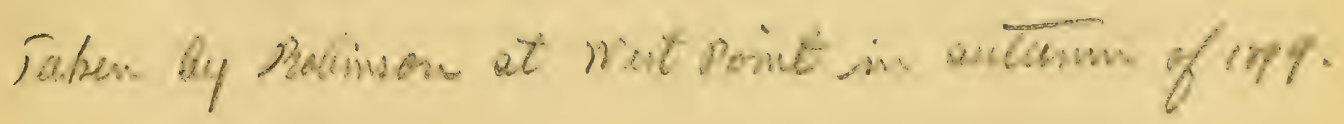



I 856 Arvicola dekayi Audubon \& Bachman, Quadr. N. Am. 3:287.

I884 Evotomys mutilus gapperi Merriam, Linn. soc. New York. Trans. $2: 173$.

I8gr Evotomys gapperi Merriam, North American fauna. 30 July I89 . no. 5, p. I 19.

I898 Evotomy's gapperi Mearns, U. S. Nat. mus. Proc. 2 I : 349.

Type locality. Region between York and Lake Simcoe, Ontario Canada.

Faunal position. While the common red-backed mouse is a typical Canadian animal, in sufficiently cool, damp localities it penetrates considerably to the south of the normal geographic limits of the boreal zone.

Habitat. In the northern part of its range this mouse is found in almost every variety of surroundings, but further south its habitat becomes more limited. In the Canadian zone it is one of the most widely dispersed mammals, in the northern part of the transition zone it is restricted to damp woods, while in the lower part of the transition zone it is never found far away from cold streams, wooded sphagnum bogs and cedar swamps. Mr Charles H. Batchelder has recently described the conditions under which the red-backed mouse occurs in the transition zone of eastern Massachusetts. He says, "What these favorable conditions are, is the most interesting question connected with the animal's [local] distribution, but it is not one that can receive a positive and final answer. Nevertheless there are some characteristic features that are common to almost all of the places where I have found it [in southeastern New England]. One may look for it with some confidence in almost any large tract of wet ground that retains its moisture through the summer, but is not subject to serious floods, and which bears a growth of woods sufficiently heavy to afford a dense shade, so that the ground beneath and the roots of the trees are covered with a deep carpet of sphagnum. If the older trees have been suffered to die a natural death, and their stumps and fallen trunks lie slowly rotting on the ground half-concealed by the sphagnum, the chance of finding it is certainly not lessened. One of the most evident peculiarities of such a spot as this, in southern New England, is that the dense shade and the abundant evaporation maintain a temperature during the hottest summer weather that is far below that of the surrounding country. In these respects of coolness, moisture and shade there is a striking resemblance to the woods Evotomys gapperi inhabits in extreme northern New England and other parts of the Canadian zone.

"The places where I have found it differ considerably in their appearance, chiefly according to the kinds of trees with which they are wooded. 
In the southern counties the conditions I have named are best afforded by the 'cedar swamps' that once were such a characteristic feature of that part of the state. These are tracts of low ground varying in area from a few acres to sometimes several square miles densely wooded with white cedar (Chamaecyparis sphaeroidea Spach). The cedars stand crowded close together each one rising from a hummock formed of its own roots and the mass of sphagnum growing on them. Between the hummocks even in summer the water lies in shallow pools, save where it is covered by a luxuriant growth of the spongy sphagnum. Sometimes here and there in spots where the cedars have opened their ranks and left. room enough for other trees to grow, there are a few red maples or white pines, and an occasional yellow birch or stunted black spruce.

"Farther north in Middlesex and Essex counties where these cedar swamps are comparatively few and seldom large, Evotomys often finds its home in swampy woods of old red maples, where the thick foliage of the spreading branches casts a dense shade, sometimes made even darker by an undergrowth of tall shrubs, among which the high-bush blueberry (Vaccinium corymbosum) is the chief. Here too sphagnum flourishes, and covers the roots and hummocks that rise a little above the lower levels of the wet ground" ('96a, p. 192-93). What $\mathrm{Mr}$ Batchelder says about the habitat of the red-backed mouse in Massachusetts applies equally well to the animal's haunts in New York south of the Adirondacks. Here however dense thickets of arbor vitae (Thuja occidentalis) generally replace the 'cedar' swamps.

Distribution in New York. In New York the common red-backed mouse occurs abundantly throughout the Canadian forests. The details of its distribution south of this region are very imperfectly known, but the animal is to be looked for in suitable localities throughout the state.

Principal records. De Kay: "We have little to add except that it was first obtained from low grounds in the neighborhood of Oneida lake. I subsequently found it in great numbers in the forests of Hamilton and St Lawrence counties" ('42, p. 86).

Merriam: "The red-backed mouse is abundant in all parts of the Adirondacks. It occurs on the summits of the tree-covered mountains as well as in the deepest valleys. It is essentially a wood species in its local distribution, rarely frequenting the beaver meadows or the fields of the farmer. It often enters the woodman's camp, and I have sometimes caught it even in the luxurious log-houses which have, during the past few years, supplanted the old-time shanties in many parts of the Adirondacks" ('84d, p. I73). 



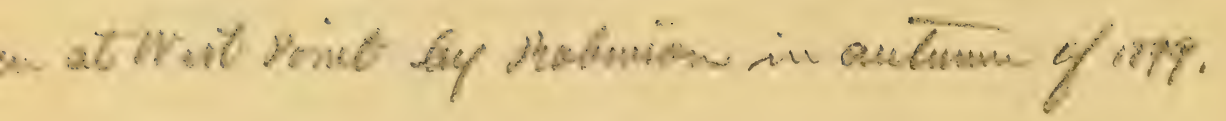


Mearns: "This mouse was not found on the immediate banks of Schoharie creek although such Canadian forms as Tamias striatus lysteri, Peromyscus canadensis, Sorex fumeus, and Zapus insignis were there in abundance. It was met with in woods close to Kaaterskill junction (altitude I 700 feet) and on the lower slopes of East Kill mountain, on the opposite (right) side of Schoharie creek at the level of about 2000 feet. Above these points it increased in abundance until on the summit of Hunter mountain (altitude 4025 feet) it became so numerous that it was difficult to trap any other small mammal there. In the hardwood forests at low altitudes it was usually taken about moss-covered logs and in hollow stumps in dense woods, but on higher ground it was common everywhere" ('98b, p. 349-50).

I have found the common red-backed mouse abundant at Peterboro, Madison co, and Elizabethtown, Essex co.

$\mathrm{Mr}$ Savage has not yet taken it in the vicinity of Buffalo.

\section{Evotomys gapperi rhoadsi Stone Neze Jersey red-backed mouse}

I893 Evotomys gapperi rhoadsi Stone, American naturalist. 'Jan. I893. p. 55 .

I897 Evotomys gapperi rhoadsi Bailey, Biolog. soc. Washington. Proc. I I : 125.

ı 898 Evotomys gapperi rhoalsi Mearns, Am. mus. nat. hist. Bul. 9 Sep. I898. Io: 333 .

I898 Evotomys gapperi rhoadsi Mearns, U. S. Nat. mus. Proc. 2 I : 350 .

Type locality. May's landing, New Jersey.

Faunal position. This animal is at present known to occur in cool, probably boreal localities in the transition zone.

Habitat. In New Jersey this mouse occurs in cranberry bogs near the coast (Stone, '93, p. 55-56). In New York it has been found in a sphagnum bog overgrown with spruce and tamarack.

Distribution in New York. At present the only known locality at which this animal occurs in New York is in the higher part of the Hudson highlands.

Principal records. The only record of Evotomys gapperi rhoadsi in New York is the following in Dr Mearns's paper on the Mammals of the Catskills. "Farther south, in the Hudson highlands, only the subspecies rhoadsi was found. It occurred in sphagnous swamps overgrown with black spruce and tamarack in the highest part of the mountains, where a single immature specimen was trapped September 30 , r896. 
This individual, which I have compared with topotypes of Evotomy's gapperi rhoadsi in the departm ent of agriculture collection, appears to be of this form. - The specimen (No. $82,83_{2}$ U. S. N. M.) shows very little of the red dorsal area, the back being brownish gray as described by $\mathrm{Mr}$ Stone and quite unlike any of the Catskill specimens" (' $98 \mathrm{~b}$, p. $35^{\circ}$ ).

Remarks. This record appears to me open to serious question, though under the circumstances I see no other course than to include it as it stands.

Microtus chrotorrhinus (Miller) Rock vole

I894 Arvicola chrotorrhinus Miller, Boston soc. nat. hist. Proc. 24 Mar. 1894. 21:19o.

I 896 Microtus chrotorrhinus Bangs, Biolog. soc. Washington. Proc. 9 Mar. 1896. 10: 49 .

I 898 Microtus chrotorrhinus Mearns, U. S. Nat. mus. Proc. 2 I : 349 .

Type locality. Mount Washington, New Hampshire.

Faunal position. The rock vole is so slightly known that its faunal position can not now be definitely stated. Apparently it is a member of the Hudsonian fauna, reaching the Canadian zone in the coldest situations only.

Habitat. Damp, heavy spruce woods in the Hudsonian zone (Allen, ' $94 \mathrm{a}$, p. roz, Bangs, ' $96 \mathrm{~b}$, p. 49), cold rock cavities in the Canadian zone (Miller, '94, p. 192-93, Batchelder, '96a, p. 188). Batchelder thus describes the habitat of this animal at Beedes, Essex co., New York: "This place was a steep hillside heavily wooded with an old mixed growth. The lower slopes were made up of a talus of large angular blocks of rock piled one upon another as they had fallen from the cliffs above. The damp rocks were covered with sphagnum and ferns, and from the holes and spaces between them came currents of cold air, indicating the presence of masses of yet unmelted ice somewhere in the depths below. . . . I trapped for two days at the foot of another talus ... Here the huge rocks gave little foothold for the large trees, but the masses of ice beneath, of which glimpses could be had here and there, in the caverns between the rocks, aided by the shade afforded by a wall of mountain, produced a temperature so low that spring flowers blossomed even in August among the deep beds of damp sphagnum that covereti the rocks" ('96a, p. 188).

Distribution in New York. The rock vole has been found at only two localities in New York, at Beedes, Essex co. and on Hunter mountain in the Catskills. It probably occurs among the mountains of the 


northern part of the state wherever the requirements of its Hudsonian nature are met.

Principal records. Batchelder: "At Beedes, Essex co. N. Y. late in the summer of $\mathbf{1} 894 \ldots$. I made . . . the very unexpected discovery that Microtus chrotorrhinus was common there, at least in one particular locality" ('96a, p. I88). Mearns: "One adult male was trapped in a pile of moss-covered rocks on a shoulder of Hunter mountain, at an altitude of about 3500 feet, August 25, 1896. Many traps were subsequently placed about this spot, but no others were caught" (' 98, p. 349).

\section{Microtus pennsylvanicus (Ord) Common meadow monse}

18i5 Mus pennylvanicus Ord, Guthrie's geography. Am. ed. 2 p. 292. I825 Arvicola riparius Ord, Acad. nat. sci., Philadelphia journ. v. 4 pt. 2, p. 305,1825 .

I842 Arvicola riparius De Kay, Zoology of New York, Mammalia. p. 84 . I842 Arvicola hirsutus De Kay, Zoology of New York, Mammalia. p. 86. 1842 Arvicola oneida De Kay, Zoology of New York, Mammalia. p. 88. I842 Arvicola xanthognathus De Kay, Zoology of New York, Mammalia.

p. 90 .

I884 Arvicola riparius Merriam, Linn. soc. New York. Trans. 2 : I 74. 1895 Microtus pennsylvanicus Rhoads, American naturalist. Oct. I895. 29: 940.

I896 $M$ [icrotus] pennsylvanicus Fisher, The Observer. May 1896 . $7: 198$.

I898 Microtus pennsylvanicus Mearns, Am. mus. nat. hist. Bul. 9 Sep. I898. то: 333 .

I898 Microtus pennsylvanicus Mearns, U. S. Nat. mus. Proc. 2 I : 348 .

Type locality. Near Philadelphia, $\mathrm{Pa}$.

Faunal position. The common meadow mouse ranges from well within the Canadian zone nearly to the northern edge of the lower austral zone. In the Hudsonian zone it is replaced by a smaller softfurred race Microtus pennsylvanicus fontigenus (Bangs, '96b, p. 48, Miller, '97b, p. I4), and in the upper part of the upper austral zone by a much darker form M. pennsylvanicus nigrans (Rhoads, '97d, p. 307).

Habitat. Open, grassy places both wet and dry.

Distribution in New York. The meadow mouse is one of the most abundant mammals throughout the cleared portions of the state. Its range has undoubtedly been very much extended by the removal of the forests, and consequent increase in the area of grass lands. 
Principal records. DeKay: "The marsh meadow mouse is not uncommon in various parts of the state. I have seen specimens from Oneida, Seneca and Otsego counties" ('42, p. 85 under Arvicola riparius). "It occurs in various parts of the state" ('42, p. 88 under Arvicola hirsutus). "This species is common in the western part of the state. My specimens were obtained from the neighborhood of Oneida lake" ('42, p. 89, under Arvicola oneida). "This meadow-mouse is found in various parts of the state" ('42, p. 90 under Arvicola xanthognathus).

Merriam: "The meadow mouse is common in the cleared lands within and around the Adirondack region. It occurs on many of the beaver meadows, but is never abundant in the coniferous forests" ('84d, p. I74).

Fisher: "Very common in the low wet meadows especially near streams" ('96, p. 198).

Mearns: "Specimens were taken from fields bordering Schoharie creek (altitude I 700 feet) and on the ridge of Hunter mountain at an altitude of 3900 feet" ('98, p. 348).

I have found the meadow mouse abundant at Geneva, Ontario co. Peterboro, Madison co. and Elizabethtown, Essex co.

Mr Savage reports the species abundant in Erie co. Mr Helme writes, "This animal is found quite plentifully in the upland fields of Long Island, but is more abundant around the marshes and salt meadows."

Remarks. Although the meadow mouse is popularly considered one of the worst farm pests, Mr Samuel N. Rhoads has recently published a lengthy vindication of the animal (' 98 a, p. I $43-44$ and ' 98 b, p. 57 I -8 I).

\section{Microtus nesophilus Bailey Gull Island mouse}

I889 Arvicola riparius Dutcher, Auk. Ap. 1889. $6: 125$.

I898 Microtus insularis Bailey, Biolog. soc. Washington. Proc. 30 Ap. 1898. i i : 86 (not Lemmus insularis Nilsson, Ofversigt af Kongl. Vetenskaps-Akademiens Förhandlingar, Årg. I, 20 Mar. 1844. 34).

i898 Microtus nesophilus Bailey. Science, N. S. 2 Dec. 1898. 8: 783 .

Type locality. Great Gull Island, Long Island, New York.

Faunal position. Transition zone.

Distribution in New York. This species was confined to two small islands in Long Island sound, off the extreme northeastern point of Long Island, Little Gull Island and Great Gull Island. It is now probably extinct as shown by the following notes kindly furnished by $\mathrm{Mr}$ Arthur. H. Howell: "On August 8, 1898 in company with Mr A. H. 

Helme I visited Great Gull Island for the purpose of learning the condition of the colony of meadow mice that formerly existed there. Careful search on every part of the island for signs or runways of the mice failed to reveal any indication whatever of their presence. The natural conclusion is that the race has been nearly if not quite exterminated. The cause is not difficult to see. Within the past year the island, which contains only about I 5 acres, has been occupied by the United States government as a coast defence station, and the construction of forts at each end of the island has necessitated disturbances of the soil and change in the topography of practically the whole surface. The forts themselves with the shanties erected for the use of the laborers cover a considerable portion of the island, hills have been levelled, the little fresh water swamp has been filled in, and the whole surface twice burned over. The destruction of all the rubbish and dead vegetation deprived the mice of any cover where they could seek shelter, and the sparseness of the new growth made it easy for us to examine every available hiding place. Doubtless any of the mice which may have escaped the fires were captured by the cats which roam at will over the island.

"On the same day we visited Plum island, situated between Great Gull Island and the eastern end of Long Island. Here we found Microtus quite abundant about the edges of the swamps on the western end of the island, and a series of I 4 was secured. Comparison of these specimens with the mainland form shows that the Plum island mouse is like the latter and entirely different from Microtus nesophitus."

Principal records. The first published record of this mouse is contained in a paper by Dr Basil Hicks Dutcher on the birds of Little Gull Island ('89). Dr Dutcher says, "Great Gull Island was purchased by the Government to serve as a garden for the keepers of the Little Gull Light, but it was so overrun with mice that it was useless for the purpose. . . . I secured one specimen of the resident mouse, which proved to be a juvenile Arvicola riparius." This specimen afterward became $\mathrm{Mr}$ Bailey's type of Microtus insularis. Mr J. Harris Reed has recently described in considerable detail the fortifications on Great Gull Island and their effect on the fauna of the place (' 98, p. $4 \mathrm{r}-43$ ).

Mr Frank M. Chapman informs me that he visited Great Gull Island during the summer of 1889 . He found the mouse colony in the same flourishing condition described by Dr Dutcher. Seven specimens which he collected are now in the American museum of natural history. 
Microtus pinetorum scalopsoides (Audubon and Bachman)

Northern pine mouse

I84 I Arvicola scalopsoides Audubon and Bachman, Acad. nat. sci. Philadelphia. Proc. $1: 97$.

I85I Arvicola pinetorn Audubon and Bachman, Quadr. N. Am. $2: 2$ I 6 .

I88 5 Arvicola pinetorum Merriam, American naturalist. 19:895. 1896 Microtus pinetorum Fisher, The Observer. May 1896. $7: 198$. I896 Microtus pinetorum scalopsoides Batchelder, Boston soc: nat. hist. Proc. Oct. $1896.27: 187$.

Type locality. Long Island.

Fannal position. Upper austral zone, and irregularly parts of transition zone.

Habitat. Light dry soil in woods, thickets and fields.

Distribution in New York. The pine mouse is abundant on Long Island and in the lower Hudson valley. Beyond this general region I know of but two positive records of its occurrence, at Locust Grove, Lewis co. and at Peterboro, Madison co.

Principal records. Audubon and Bachman: "This species, of which we have obtained many specimens from Long Island, and which is not rare in the vicinity of New York, is very distinct from Wilson's meadow mouse" ('4r, p. 97). Merriam: "On the I3th of June, r884 at my home in Lewis county, New York, I caught a female pine mouse (Arvicola pinetorum Le Conte). It was taken in a trap baited with beechruts and set for the red-backed wood mouse (Evotomys nutilus gapperi) at the roots of a maple in the border of a hardwood forest" ('85, p. 895). Fisher, "Until the present year [1885] we have never detected the pine mouse (Arvicola pinetorım) in this locality [Sing Sing]" ('85, p. 896). "Tolerably common [at Sing Sing]. Its favorite resorts are the dry grassy hillsides more or less grown up with small bushes and briers, and old orchards containing weeds, matted grass, and young saplings" ('96, p. $19^{8) .}$

I have taken two specimens of the pine mouse at Peterboro, Madison co. One of these was caught September ${ }^{1} 5,1892$ in a cyclone trap set without bait in a labyrinth of short-tailed shrews' tunnels in the edge of a grove of hard wood. The other, taken September r, I893, was secured with a cyclone trap set in a woodchuck's burrow beneath the roots of a large elm in a low, damp wood lot. I have never seen the characteristic, mole-like tunnels of the pine mouse at Peterboro where 


the animal is probably a mere straggler. Mr Savage has not yet found the pine mouse in Erie co., where however it doubtless occurs. Mr Helme writes that it is abundant in the dry upland fields and woods of Long Island.

\section{Fiber zibethicus (Linnaeus) Muskrat}

I766 Castor zibethicus Linnaeus, Systema naturae. ed. I2. I : 79 .

I8I 7 Fiber zibethicus Cuvier, Règne animal. I : I92.

I842 Fiber zibethicus De Kay, Zoology of New York, Mammalia.

\section{p. 75 .}

1884 Fiber zibethicus Merriam, Linn. soc. New York. Trans. 2 : 177.

I896 Fiber zibethicus Fisher, The Observer. May I896. 7: ig8.

I898 Fiber zibethicus Mearns, Am. mus. nat. hist. Bul. 9 Sep. 1898 . Io: $33^{2}$.

I898 Fiber zibethicus Mearns, U. S. Nat. mus. Proc. 2 I : 348 .

Type locality. Eastern Canada.

Faunal position. As the muskrat is essentially an aquatic animal its distribution is not limited by the same climatic conditions that govern the ranges of most mammals. It is therefore at present impossible to assign the animal any definite faunal position. The difficulty is increased by the fact that little is known of the geographic variations to which the species may be subject. Muskrats range through all the life zones from Hudsonian to lower austral inclusive.

Habitat." Marshes and the borders of lakes, ponds and sluggish streams.

Distribution in New York. There are probably very few square miles of the state in which the muskrat does not now occur. This is probably one of the few mammals whose range has not been sensibly increased or diminished by the clearing and settling of the state.

Principal records. De Kay: "The geographic range of the musquash is very extensive, being found from $30^{\circ}$ to $69^{\circ}$ north latitude" ("42, p. 76). Merriam: "Colonies of muskrats may be found at suitable ponds, swamps and sluggish streams in all parts of the Adirondacks" (" $8_{4} \mathrm{~d}$ p. I77). Fisher: "Common [near Sing Sing] in the salt meadows, tide creeks and all the streams and ponds" ('96, p. I98). Mearns: "The muskrat is abundant at Kaaterskill lake. It is also said to occur along Schoharie creek, but we saw no signs of it there" ('98, p. 348).

I have found the muskrat common at Geneva, Ontario co. Peterboro, Madison co. and Elizabethtown, Essex co. Mr Savage writes, "The muskrat is abundant locally [in Erie co.]. During a recent flood in 
South Buffalo (January 6, 1898 ) an acquaintance of mine with two companions secured 54 rats along the railroad embankments within the city limits, and another person shot 18 in the same section." Of the muskrat on Long Island Mr Helme says, "It is common in all sections where there are suitable ponds, swamps or streams. It occasionally is found in the salt marshes."

\section{Synaptomys cooperi Baird Bog lemming}

I $85^{8}$ Synaptomys cooperi Baird, Mam. N. Am. p. $55^{8}$.

1896. Synaptomys cooperi Batchelder, Boston soc. nat. hist. Proc. $27: 185$.

Type locality. Northern New Jersey?

Faunal position. The bog lemming is probably a Canadian mammal, but it occurs in cold situations throughout the transition zone and even in the northern edge of the upper austral zone.

Habitat. Cold bogs, either wooded or open.

Distribution in New York. While Synaptomys cooperi probably occurs in nearly every county of the state, it has as yet been taken in only two localities, Beedes, Essex co. and Glenwood, Erie co.

Principal records. Batchelder: "In the summer of 1895 I was surprised to find this species in the Adirondack mountains at Beedes, Essex

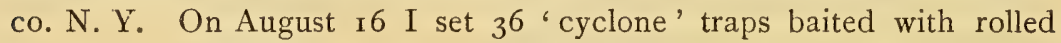
oatmeal in some low ground, wooded chiefly with large yellow birches, sugar maples and beeches, with more or less thin, tall undergrowth (chiefly Acer spicatum Lam. and $A$. pennsylvanicum $L$.), and with many mossy rotten logs and stumps scattered over it. A dozen of the traps were along the edge of some wetter, almost swampy, ground where more of the larger trees had been cut and there was a thick growth of small trees, chiefly Acer spicatum. Two days later, August I8, I found an adult male Synaptomys cooperi caught in a trap set at the foot of a large rotten stump in the edge of the swampy ground. Three days later I caught an immature female near by, also in the edge of the swampy ground, in a trap placed under a rotten log. Two days after this I got still a third, another adult male, this time in the open drier part of the woods 30 or 40 yards from the wet ground" ('96a, p. I 85 ).

Mr Savage has sent me for examination the skin and skull of a Synaptomys cooperi that he shot at Glenwood, Erie co. December 3I, 1897. When killed the animal was running in a sleigh track in the woods. The specimen is not fully mature but I have little hesitation in referring it to this species. 


Synaptomys fatuus Bangs Northern bog lemming

I896 Synaptomys fatunis Bangs, Biolog. soc. Washington. Proc. 10:47. I 898 Synaptomys fatuns Mearns, U. S. Nat. mus. Proc. 2 I : 348.

Type locality. Lake Edward, Quebec.

Fannal position. Synaptomys fatuns appears to be a member of the Hudsonian fauna, entering the normal area of the Canadian zone in very cold situations only.

Habitat. Bogs and damp woodlands.

Distribution in New York. The northern bog lemming has been taken only once in New York, near the summit of Hunter mountain in the Catskills.

Principal records. Mearns: "A single specimen of this species was trapped near the summit of Hunter mountain, the locality being a marshy place strewn with fallen trees at the altitude of 3900 feet." ('98, p. 348).

Remarks. The occurrence of this Hudsonian species in the Catskills is very unexpected, and further material to verify the identification of the Catskill animal is greatly to be desired. This peculiar distribution is however very closely paralleled by that of Microtus chrotorrhinus.

Zapus hudsonius (Zimmermann) Meadow jumping-mouse

I780 Dipus hudsonius Zimmermann, Geogr. Gesch. 2:358.

I842 Meriones americanus De Kay, Zoology of New York, Mammalia, p. 7 o.

1872 Zapus hudsonius Coues, U. S. Geol. and geogr. surv. terr. Bul. ser. 2. no. 5. p. 254 .

I884 Zapus hudsonius Merriam, Linn. soc. New York. Trans. 2: I92 (part).

r896 Zapus hudsonicus Fisher, The Observer. May i896. 7: 198.

I898 Zapus hudsonius Mearns, U. S. Nat. mus. Proc, 2 I : 347.

I898 Zapius hudsonius Mearns, Am. mus. nat. hist. Bul. 9 Sep. 1898. 10: $33^{2}$.

Type locality. Hudson bay.

Faunal position. Hudsonian, Canadian and transition zones.

Habitat. Meadows, damp brushy fields, the edges of woodlands and marshes bordering northern lakes. Wherever the animal occurs it seeks the most open, grassy situations available.

Distribution in New York. The meadow jumping-mouse occurs in favorable localities throughout New York state. Its range has doubtless been greatly extended, or rather the amount of land suited to its needs has been greatly increased by the clearing away of the forests. 
Principal records. De Kay: "This curious little animal although rarely seen, is not uncommon in every part of the state" ('42, p. 7 I). Merriam: "The jumping-mouse is common in many parts of the Adirondacks as well as in the surroundlng country" ('84d, p. 192). Fisher : "Tolerably common. Usually found in the tall grass of wet meadows near streams, but occasionally observed in dry pastures" ('96, p. I98). Mearns: "Abundant along Schoharie creek, but not found elsewhere in the [Catskill] region" ('98, p. 347).

I have found the meadow jumping-mouse abundant at Peterboro, Madison co. where it never penetrates the dense woods inhabited by Napaeozapus insignis. The two species frequently occur together however in thinly wooded places. About this animal in Erie co. Mr Savage writes as follows: "With all my rambling about I never met with Zapus, but have heard of it from persons qualified to distinguish it from the white-footed mouse." Mr E. M. Chamot in a letter from Ithaca March I 5, I 896 writes me that he once took a specimen of Zapus in deep woods at Angola, Erie co. May it not have been $Z$. insignis? Mr Helme reports the meadow jumping-mouse fairly common on Long. Island.

Remarks. De Kay figures this species ('42, pl. 24) and his account evidently refers wholly to it. Merriam on the other hand includes both meadow and woodland animals under the name husdonius.

I once saw a remarkable demonstration, though a negative one, of the function of the exceedingly long tail of this animal. A young individual had lost its tail by the knife of a mowing machine in a damp meadow and was rendered thereby helpless. Not that its jumping power was in any way impaired, on the contrary. I have seldom seen a mouse of the size leap more energetically or to greater distances. But the animal had lost all control over its movements. When I approached, it made violent efforts to escape, but the moment it was launched in air, its body, deprived of its balancing power, turned end over end so that it was as likely as not to strike the ground facing the direction from which it had come. The next frantic leap would then carry it back to the starting point. An animal thus deprived of its tail would be an interesting subject for observation. I am inclined to believe that the lost coordination of movements would eventually be restored.

Napaeozapus ${ }^{\alpha}$ insignis Miller Woodland jumping-mouse I884 Zapus hudsonius Merriam, Linn. soc. New York. Trans. 2: I92(part). I89 I Zapus insignis Miller, American naturalist. Aug. I89г. 25:743.

$a$ Characterized (as a subgenus) by Preble, North American fauna No. 15, p. 33. August 8, 1899. 


I893 Zapus insignis Miller, Biolog. soc. Washington. .Proc. 22 Ap. 1893. 8: I.

1898 Zapus insignis Mearns, U. S. Nat. mus. Proc. $21: 348$.

Type locality. Restigouche river, New Brunswick.

Faunal position. The woodland jumping-mouse is an inhabitant of the Canadian zone, reaching the transition zone in 'boreal islands ' only.

Habitat. Forests and woodlands, specially in the neighborhood of running water.

Distribution in New York. The woodland jumping-mouse probably occurs throughout the Adirondack wilderness and in isolated colonies in other parts of the state wherever the fauna has a distinctly Canadian tinge. At present however it has been recorded from the following localities only: Keene, Essex co. (Miller, '93a, p. I), Elizabethtown, Essex co. (Miller, '93a, p. r), Peterboro, Madison co. (Miller, '93a, p. x) and the Catskills (Mearns' ' 98, p. 348). There is a specimen in the U. S. National museum taken at Glenville, Schenectady co. by P. M. Van Epps. Settlement of the county has probably restricted the range of Napaeozapus to nearly the extent that it has increased that of true Zapus.

\section{Erethizon dorsatus (Linnaeus) Canada porcupine}

I $75^{8}$ Hystrix dorsatus Linnaeus, Syst. nat. ed. Iо. I : 56 .

1822 Erethizon dorsatus F. Cuvier, Mem. du mus. d'hist. nat. Paris. $9: 43^{2}$.

I842 Hystrix hudsonius De Kay, Zoology of New York, Mammalia. p. 77 .

I884 Erethizon dorsatus Merriam, Linn. soc. New York. Trans. $2: 202$. I898. Erethizon dorsatus Mearns, U. S. Nat. mus. Proc. 2 I : 346.

Type locality. Eastern Canada.

Fannal position. Boreal and transition zones.

Habitat. Heavy forests.

Distribution in New York. The porcupine is common throughout the Adirondacks and in the Catskills. In other parts of the state it prob ably occurs wherever there are sufficiently extensive tracts of unbroken forest.

Principal records. De Kay: "In this state more particularly in the northern and western counties they are quite numerous" (42, p. 79). Merriam: "The porcupine is a common and well known resident of all the wooded parts of the Adirondacks" ('84, p. 202). Mearns: "This' 
remarkable beast was formerly abundant throughout this region [the Catskills]. During recent years it has become comparatively scarce except on the mountains. The skeleton of a porcupine was found under the fallen ruins of an observatory on the summit of Hunter mountain; two other specimens were subsequently trapped there (altitude 4025 feet); three were taken at a spring under a shelving rock, at the altitude of 3800 feet, and a seventh was overtaken and killed in the slide rock on the side of Hunter mountain at about 3000 feet altitude" ('98, p. 346). Lucas ('82, p. 7) records a specimen taken near Rochester, Genesee co. in $188 \mathrm{I}$.

There is a porcupine in the New York state museum taken at McKownville, Albany co.

Mr Savage writes as follows of the occurrence of the porcupine near Buffalo, "The porcupine is to be found in the wilder parts of the southern tier of counties. I have seen a fine big male from near Cherry creek, Chautauqua co. My friend Roger Fitch has shot it near Westfield in the same county. In the fall of 1894 one was brought into Gowanda, Erie co. by a squirrel hunter. I also saw one in August or September, I 896 , that had been killed by boys at Blasdell six miles from Buffalo."

\section{Lepus floridanus mallurus (Thomas) Sontheastern cottontaic} I837 Lepus sylvaticus Bachman, Acad. nat. sci. Philadelphia. Journ. 7 pt. 2: 403 (part). Not Lepus borealis sylvaticus Nilsson. I832.

I842 Lepus nanus De Kay, Zoology of New York, Mammalia. p. 94 (part).

I895 Lepus sylvaticus Bangs, Boston soc. nat. hist. Proc. 26: 405 . ז896 Lepus sylvaticus Fisher, The Observer. May 1896. 7: 198. I 898 Lepus sylvatucus Mearns, Am. mus. nat. hist. Bul. 9 Sep. 1898. 10: 33 I.

I898 Lepus muttalli mallurus Thomas, Ann. and Mag. nat. hist. ser. 7 Oct. $1898.2: 320$.

I899 Lepus floridanus malhurus Allen, Am. mus. nat. hist. Bul. 4 Mar. I 899. I $2:$ : 3 .

Type locality. Raleigh, North Carolina.

Faunal position. Upper and lower austral zones.

Habitat. "Lepus sylvaticus lives in the open fields and broom-grass stretches, in the rank growth of weeds along 'creeks', and in the open southern woods, seldom if ever living in the denser parts of woods or swamps" (Bangs, '95, p. 4I 2). 


Distribution in New York. The southern cottontail barely reaches the southeastern extremity of New York.

Principal records. Bangs: Specimens recorded from Hastings, Oswego co. and South Nyack, Rockland co. ('95, p. 4II). Fisher: "Common [at Sing Sing]. Although hundreds are killed every winter nevertheless they appear to be just as common at the present time as 20 years ago" ('96, p. I98). Mearns : "Fairly common throughout the [Hudson] highlands and found everywhere, from the brackish marshes beside the Hudson to the tops of the highest mountains. Some individuals, those from the highest localities, verge towards the subspecies transitionalis of Bangs, which is the only form of this species found about Fort Miller r 50 miles higher up the Hudson in Washington co. N. Y." ('98a, p. 33 r).

I have never met with this rabbit in New York, but Mr A. H. Howell and $\mathrm{Mr} \mathrm{A}$. H. Helme have shown me specimens from Long Island. Mr Helme's specimens have been identified by Mr Outram Bangs.

\section{Lepus floridanus transitionalis (Bangs) Northeastern cottontail}

I837 Lepus americanus Bachman, Acad. nat. sci. Philadelphia. Journ. v. 7, pt. 2. p. 326 (part).

1837 Lepus sylvaticus Bachman, Acad. nat. sci. Philadelphia. Journ. v. 7, pt. 2. $7: 403$ (part).

1842 Lepus nanus De Kay, Zoology of New York, Mammalia. p. 94 (part).

1884 Lepus sylvaticus Merriam, Linn. soc. New York. Trans. 2:2r3 (part).

1895 Lepus sylvaticus transitionalis Bangs, Boston soc. nat. hist. Proc. $26: 405$.

I898 Lepus muttalli transitionalis Thomas, Ann. and Mag. nat. hist. Oct. I 898 . ser. 7. $2: 320$ :

I898 Lepus sylvaticus transitionalis Mearns, U. S. Nat. mus. Proc. $21: 345$.

I899 Lepus floridanus transitionalis Allen, Am. mus. nat. hist. Bul. 4 Mar. 1899. I 2: I3.

Type locality. Liberty Hill, New London co. Ct.

Faunal position. The northeastern cottontail appears to be strictly confined to the transition zone.

Habitat. "Lepus sylvaticus transitionalis . . is seldom found in open fields but prefers the seclusion of the thickest swamps, green brier 
patches, scruboaks and old overgrown pastures that have come up to sumacs, alders, roses and various shrubs" (Bangs, '95, p. 412).

Distribution in New York. The distribution of this form of cottontail in New York is very imperfectly understood. The animal probably occurs throughout the area occupied by the transition zone in the eastern half of the state. Without much question it is rapidly pushing its way northward as the heavy forests are removed.

Principal record. Bachman: "About 30 years ago it was not known in the neighborhood of Troy, in the state of New York. The northern hare was then very abundant. The American hare soon after made its appearance in very small numbers and in proportion to its increase the former began to grow more scarce. For a time they continued to be found in the same neighborhood, but whether the two species were not reconciled to each other, or what is more probable, that the northern hare was more hunted than the other, it has become comparatively scarce whilst the American hare is exceedingly numerous" ('37a, p. 328). De Kay: "It has not a wide geographic range. It is found from New Hampshire to Florida but its western limits are not yet established" ('42, p. 95). Merriam: "The gray rabbit . . . only enters the Adirondack region along its southern border, in Fulton, Saratoga and Warren counties" ('84d, p. 2I3). Bangs: "East side of lower Hudson river" ('95, p. 4I r). Fisher: "Common [at Sing . Sing]" ('96, p. r98). Mearns: "Curiously enough this small rabbit is generally known to the residents of the upper Schoharie valley by the name of 'Jack rabbit'. I was informed by persons who had lived near Kaaterskill junction for many years that this rabbit had extended its range upward into the cleared lands of the Schoharie valley during recent years " ('98b, p. 345).

\section{Lepus floridanus mearnsi Allen Eastern prairie cottontail}

I894 Lepus sylvaticus mearnsi Allen, Am. mus. nat. hist. Bul. 3r May 1894. 6: 17r.

I 895 Lepus sylvaticus mearnsi Bangs, Boston soc. nat. hist. Proc. $26: 406$. r898 Lepus nuttalli mearnsi Thomas, Ann. and Mag. nat. hist. Oct. i 898 . ser. 7. $2: 320$.

r899 Lepus floridanus mearnsi Allen, Am. mus. nat. hist. Bul. 4 Mar. I899. I $2:$ I 3 .

Type locality. Fort Snelling, Minnesota.

Faunal position. Transition and upper austral zone.

Habitat. Prairies and open fields. 


Distribution in Nere York. The eastern prairie cottontail probably occurs throughout the western half of New York. The only published record of its presence in the state rests however on two specimens from Peterboro, Madison co (Bangs, '95, p. 406). The animal has undoubtedly extended its eastward range very rapidly during the past $5^{\circ}$ years as the clearing away of the heavy forests has increased the area suited to its needs (Miller, '95a, p. 410). Mr Savage writes that cottontails are common near Buffalo. From measurements which he sends me of six specimens shot at Cherry creek, Chautauqua co. in January r898, I think there can be no doubt that the form occurring there is Lepus floridanus mearnsi.

Lepus americanus virginianus (Harlan) Southern varying hare I825 Lepus virginianus Harlan, Fauna Americana. p. I96. r842 Lepus americanus De Kay, Zoology of New York, Mammalia. p. 95. 1877 [Lepus americanus] var. virginianus Allen, Monogr. N. Am. Rodentia. p. 307.

I884 Lepus americanus Merriam, Linn. soc. New York. Trans. 2:207. 1884 Lepus americanus virginianus Merriam, Linn. soc. New York. Trans. $2: 211$.

1898 Lepus americanus virginianus Bangs, Biolog. soc. Washington. Proc. $12: 79$.

I898 Lepus americamus virginianus Mearns, U. S. Nat. mus. Proc. 2 I : 346.

Type locality. Blue mountain of Pennsylvania.

Faunal position. The southern varying hare is an inhabitant of the boreal zone, penetrating the limits of the transition zone in specially favorable localities only. "That it has a weak hold upon a place in the fauna of the transition zone is shown by the rapidity with which it disappears when the conditions that enabled it to exist there are slightly changed" (Bangs, '98, p. 81).

Habitat. Damp, cool woods and forests.

Distribution in Neze. York. This animal occurs throughout the northern part of the state, and in suitable isolated localities farther south where it has not yet been exterminated. It is one of the species whose range has been greatly restricted by the clearing away of the heavy forests.

Principal records. De Kay: "It occurs in most parts of the state and is often called the white rabbit. In the winter the markets of New York are abundantly supplied with this species from the Kaaterskill and Shawangunk (Shongo) mountains" ('42, p. 96). Merriam: "The northern hare is found in greater or less abundance in most parts of the Adirondacks" ('84d, p. 207). Mearns: "This hare is abundant on the 
summits of East Kill, Plateau and Hunter mountains, descending at times along belts of coniferous trees nearly to Schoharie creek. In the lowest country it is said to be almost wholly replaced by the cottontail" ('98b, p. 346).

I have found the southern varying hare locally common at Peterboro, Madison co. and abundant at Elizabethtown, Essex co. Of the occurence of this species near Buffalo, Mr Savage writes: "The varying hare is becoming rare or local. On December 8, I897 I saw four on R. \& P. r. r. train that were shot at West Valley, Cattaraugus co. Also heard of their being taken near Java, Wyoming co. in the autumn of 1897. On January 29, 1898 , one was shot near Cherry creek, Chautauqua co.

Remarks. The northern varying hare Lepus americanus americanus Erxleben was formely supposed to occur in New York (see Merriam, ' 84 d, p. 207) but Bangs has recently shown that the southern boundary of its range does not reach the northern edge of the United States ('98, p. 78).

\section{Felis oregonensis hippolestes Nerriam) Northeastern panther} I842 Felis concolor De Kay, Zoology of New York, Mammalia. p. 47. 1882 Felis concolor Merriam, Linn. soc. New York. Trans. p. I : 29. 1897 Fellis hippolestes Merriam, Biolog. soc. Washingtón. Proc. 11 : 219. 1899 Felis 5 July 1897.
6 Jan. 18 89.9 .

Type locality. Wind River-mountains, Wyoming.

Faunal position. The northeastern panther was formerly an inhabitant of the Canadian, transition and upper austral zones. It is now exterminated in all but the first named.

Habitat. Forests.

Distribution in New York. This animal still exists in the wilder portions of the Adirondacks. Elsewhere it is extinct within the limits of the state.

Principal records. DeKay: "In this state the panther is most numerous in the rocky northern districts and particularly in the counties of Herkimer, Hamilton and St Lawrence. They are occasionally seen among the Kaaterskill mountains, and the specimen in the New. York museum ... was obtained from this locality" (' 42, p. 48). Merriam : "It is not many years since the cougar or panther, second largest of American Felide, was a common inhabitant of the primeval forests of the Adirondacks; but since the state offered a bounty [in I 871 ] for their destruction so many more have been killed than born that they are now 
Delis conguav herr.

1192. Delis cougeres Kerr, Anim, Anind., I, f.151

Iefpe trealit, - Pennsylvania. 

well nigh exterminated. However a few still remain and some years may yet elapse before the last panther disappears from the dense evergreen swamps and high rocky ridges of this wilderness" ('82 p. 29-30).

Remarks. I use the subspecific name hippolestes for the northeastern panther as the least unsatisfactory course at present open.

The data from which the following table of panther bounties has been prepared are furnished by Dr Frederick J. H. Merrill.

Table of bounties paid for panthers in New York under law of 1871

\begin{tabular}{|c|c|c|c|c|c|c|c|}
\hline \multicolumn{3}{|c|}{ County } & \multicolumn{2}{|c|}{ Town } & Date & By whom killed & \multirow{2}{*}{$\begin{array}{c}\begin{array}{c}\text { Amount } \\
\text { paid }\end{array} \\
\$ 20\end{array}$} \\
\hline Essex. & $\ldots$ & .... & Newcoml & $b \ldots \ldots$ & $10 \mathrm{~N}$ & J. C. Fanner........... & \\
\hline 6 & $\ldots$ & $\ldots$ & 16 & ....... & $11 \mathrm{D} \quad 1871$ & $66 \quad \ldots \ldots \ldots$ & 20 \\
\hline 6 & & $\ldots$ & 6 & $\ldots \ldots$ & 6 & $\ldots . . . .$. & 20 \\
\hline “ & $\ldots$. & $\ldots$ & 66 & $\ldots \ldots$ & 66 & $\ldots \ldots . . .$. & 20 \\
\hline 16 & $\ldots$. & $\ldots$ & 6 & $\ldots \ldots$ & $25 \mathrm{~F} \quad 1880$ & W. H. Cullen ......... & 20 \\
\hline$" 6$ & $\cdots$ & $\ldots$ & Wilming & ton .... & $14 \mathrm{Jl} 1883$ & $\begin{array}{l}\text { Arthur Croninshiold } \\
\text { and J. C. Sanders... }\end{array}$ & 20 \\
\hline$" 6$ & & & 66 & & $11 \mathrm{Ag} 1883$ & 66 & 20 \\
\hline 6 & & .. & 6 & $\ldots$ & $14 \mathrm{Ag} 1888$ & James Jagins ......... & 20 \\
\hline Fraukl & lin. & $\ldots$. & Dickinso & $n \ldots$. & $4 \mathrm{D}^{\circ} \quad 1872$ & M. H. Ober .......... & 20 \\
\hline "6 & & & 6 & ...... & $29 \mathrm{Ag} \quad 1873$ & C. A. Merrill ............ & 20 \\
\hline Hamilt & Iton & $\ldots$. & Lake Ple & easint... & $29 \mathrm{~F}^{\circ} \quad 1872$ & A. B. Sturges \& B. Page & 20 \\
\hline 66 & & & Long Lal & ke ...... & $29 \mathrm{~F} \quad 1878$ & J. W. Schultz........ & 20 \\
\hline 16 & & $\ldots$ & $0_{6}$ & ...... & $21 \mathrm{~J}_{\theta} \quad 1882$ & George Muir ......... & 20 \\
\hline 6 & & & 66 & ...... & 66 & 66 & 20 \\
\hline 16 & & $\ldots$ & 6 & ...... & $22 \mathrm{JI} 1882$ & - . . . . & 20 \\
\hline 66 & & $\ldots$. & 66 & $\ldots \ldots$ & $24 \mathrm{JI} \quad 1882$ & $\ldots . . . .$. & 20 \\
\hline is & & $\ldots$. & 6 & ...... & $10 \mathrm{~S}$ & $\ldots . . . .$. & 20 \\
\hline " & & $\ldots$ & "6 & .... & $280 \quad 1883$ & $\ldots \ldots . . .$. & 20 \\
\hline 6 & & $\ldots$ & 66 & ..... & 66 & $\ldots \ldots \ldots$ & 20 \\
\hline 66 & & $\ldots$. & 16 & ...... & $30 \mathrm{~N} \quad 1883$ & ........... & 20 \\
\hline 66 & & $\ldots$ & 66 & $\ldots \ldots$ & $5 \mathrm{~F}$ & $\ldots \ldots . . .$. & 20 \\
\hline 66 & & $\ldots$ & 66 & $\ldots \ldots$ & $8 \mathrm{~F}$ & $\ldots \ldots \ldots$ & 20 \\
\hline 6 & & $\ldots$. & Wells ... & ........ & $19 \mathrm{D}$ & Silas Call . . . . . . . . . . & 20 \\
\hline Herkin & mer & $\ldots$ & Wilmurt. & ......... & $11 \mathrm{D}$ & E. L. Sheppard ....... & 20 \\
\hline 66 & & $\ldots$ & " . & $\ldots \ldots \ldots$ & $12 \mathrm{D}$ & $6110 \ldots$ & 20 \\
\hline 66 & & $\ldots$. & 66 & ......... & $13 \mathrm{D}$ & " $\quad \ldots \ldots \ldots$ & 20 \\
\hline "6 & & $\ldots$ & 66 & $\ldots \ldots . . .$. & $26 \mathrm{~F} \quad 1878$ & E. N. Aruold........... & 20 \\
\hline$" 6$ & & $\ldots$ & 66 & $\ldots \ldots \ldots$ & 8 Mar 1878 & " $\quad \ldots \ldots \ldots$ & 20 \\
\hline " & & $\cdots$ & "6 & $\ldots \ldots .$. & $\begin{array}{lll}26 & \mathrm{D} & 1878\end{array}$ & A. S. Marshall ........ & 20 \\
\hline 66 & & $\ldots$ & 16 & $\ldots \ldots$ & 6 & $66 \quad \ldots \ldots$ & 20 \\
\hline "s & & $\cdots$ & 66 & ......... & $250 \quad 1882$ & George Muir .......... & 20 \\
\hline 66 & & $\ldots$. & “6 & ......... & $30 \mathrm{~N} \quad 1882$ & $0_{66} \quad \ldots \ldots \ldots$ & 20 \\
\hline "6 & & ... & “ & $\ldots \ldots \ldots$ & $10 \mathrm{My} 1883$ & $\ldots \ldots$ & 20 \\
\hline "6 & & ... & 6 & ........ & 66 & $\ldots . . . . .$. & 20 \\
\hline 66 & & ... & “6 & ........ & $2 \mathrm{Ag} 1883$ & $\ldots \ldots$ & 20 \\
\hline 6 & & $\ldots$ & 66 & ......... & 66 & $\ldots \ldots$ & 20 \\
\hline "6 & & & "6 & ......... & $8 \mathrm{Ja} \quad 1884$ & $\ldots \ldots \ldots$ & 20 \\
\hline 6 & & & $66 \quad$ & ........ & $19 \mathrm{Ja}$ & .......... & 20 \\
\hline Lewis & . & $\ldots$. & Croghan & $\ldots \ldots$ & $20 \mathrm{~N}$ & $\ldots . . . .$. & 20 \\
\hline 6 & & & $\because 6$ & $\ldots \ldots$ & $25 \mathrm{Je} \quad 1883$ & $\ldots \ldots \ldots$ & 20 \\
\hline 6 & & & 66 & $\ldots \ldots$ & $29 \mathrm{~F} \quad 1884$ & $\ldots \ldots$ & 20 \\
\hline 66 & & & Diana... & ........ & 23 Мy 1882 & $\ldots \ldots$ & 20 \\
\hline “ & & & " $\ldots$ & ......... & $10 \mathrm{Je} 1882$ & $\ldots \ldots . . .$. & 20 \\
\hline 6 & & & $\ldots$ & $\ldots \ldots$ & $28 \mathrm{~J} \mathrm{~J}_{\mathrm{\theta}} 1882$ & $\ldots \ldots$ & 20 \\
\hline 16 & & & .. & ........ & 13 JI 1882 & .......... & 20 \\
\hline 16 & & & $\ldots$ & ......... & $18 \mathrm{Ag} 1882$ & 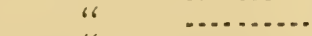 & 20 \\
\hline 6 & & & 66 & & i6 & $\ldots . . .$. & 20 \\
\hline
\end{tabular}


Table of bounties paid for panthers in New York under law of 1871, continued

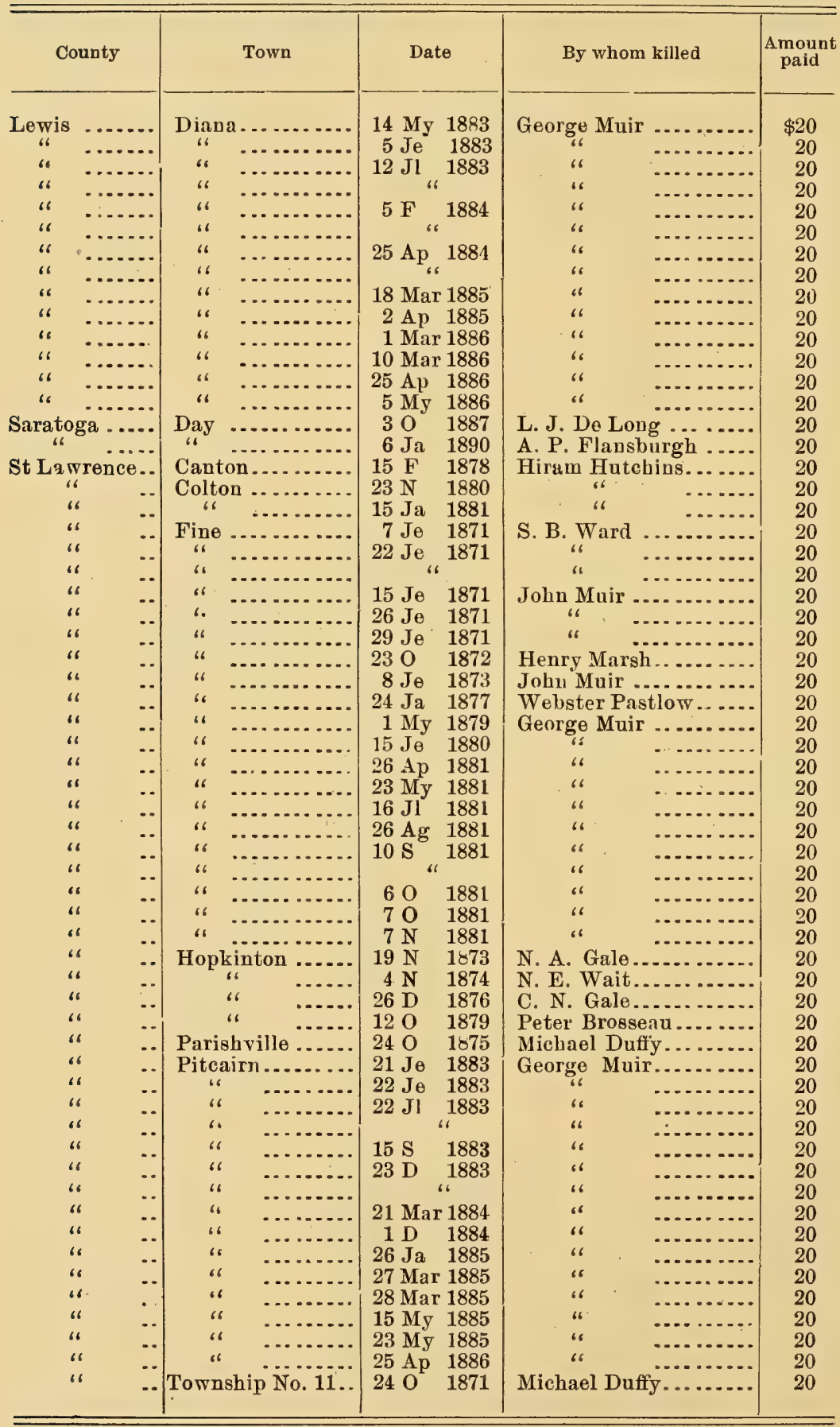




Summary by counties

\begin{tabular}{|c|c|c|}
\hline County & $\begin{array}{c}\text { Number } \\
\text { killed }\end{array}$ & $\begin{array}{l}\text { Amount } \\
\text { paid }\end{array}$ \\
\hline 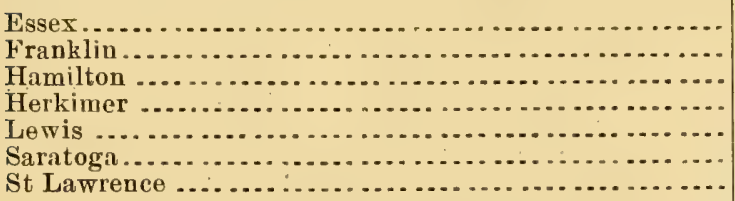 & $\begin{array}{r}8 \\
2 \\
13 \\
15 \\
23 \\
2 \\
44\end{array}$ & $\begin{array}{r}\$ 160 \\
40 \\
260 \\
300 \\
460 \\
40 \\
880\end{array}$ \\
\hline 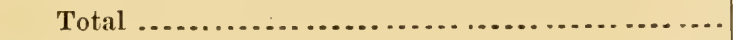 & 107 & $\$ 2140$ \\
\hline
\end{tabular}

Summary by years

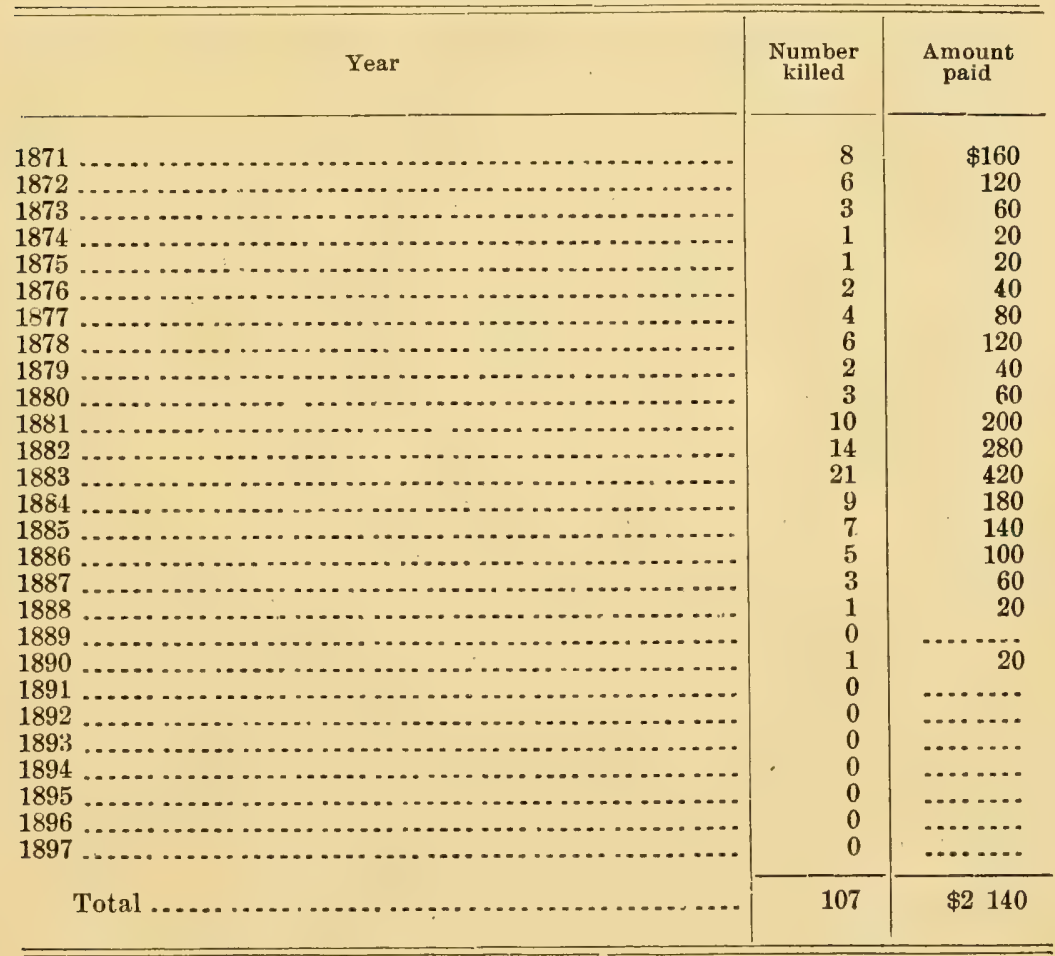

Lynx canadensis (Kerr) Canada lynx

I 792 F [elis $\rfloor$ Lynx canadensis Kerr, Animal kingdom I : I 57 . I8I 7 Lynx canadensis Rafinesque, Am. monthly magazine. $2: 46$. r8r7 Lynx montanus Rafinesque, Am. monthly magazine, 2:46. (Catskill $\mathrm{mts}$ ). 
I842 Lyncus borealis De Kay, Zoology of New York, Mammalia. p. 50. I882 Lynx canadensis Merriam, Linn. soc. New York. Trans. I:40. I898 Lynx canadensis Mearns, U. S. Nat. mus. Proc. 2 I : 359.

Type locality. Canada.

Faunal position. Hudsonian and Canadian zones, formerly perhaps transition zone also.

Habitat. Forests.

Distribution in New York. The Canada lynx is rapidly approaching extinction in New York and in fact throughout the eastern part of its range. It still exists in the Adirondacks and probably in the Catskills also.

Principal records. De Kay: "It is not uncommon in the northern districts of the state" (' 42, p. 5 I). Merriam: "The lynx is and so far as I can learn has always been a rather rare inhabitant of this region. It is most often met with on the Champlain or eastern side of the woods but is nowhere common, ('82, p. 40). Mearns: "Hunters told me that there are still a good many lynxes ... in the [Catskill] mountains. Very large tracks of a lynx which I suppose to have been this species -.were seen almost daily on the summit of Hunter mountain during the latter part of August. . . D During the winter of 1877-78 a Canada lynx was killed near Rhinebeck on the Hudson and brought to Prof. James M. De Garmo, in whose collection I saw it soon after. This is the only record of its occurrence in the immediate vicinity of the Hudson river, during recent years that has been brought to my attention" ('98, p. 359).

\section{Lynx ruffus (Gueldenstaedt) Wildcat}

I776 Felis muffa Gueldenstaedt, Novi comment. acad. scient. Imp. Petropolitanae. (I 775), $20: 484$. I 776 .

1842 Lyncus rufus De Kay, Zoology of New York, Mammalia. p. 5 I. I882 Lynx rufus Merriam, Linn. soc. New York. Trans. I : $4 \mathbf{r}$.

I896 Lynx rufus Fisher, The Observer. May 1896. 7: 198.

I897 Lynx mufus Rhoads, Acad. nat. sci. Philadelphia. Proc. p. $3^{2}$.

r898 Lynx ruffus Mearns, Am. mus. nat. hist. Bul. 9 Sep. r898. 10:35r. I898 Lynx ruffus Mearns, U. S. Nat. mus. Proc. 2 I :359.

Type locality. New York.

Faunal position. Canadian, transition and upper austral zones.

Habitat. Forests.

Distribution in New York. The wildcat, which once ranged throughout the state, appears to be now exterminated except in the wilder parts of the Adirondacks, the Catskills and the Hudson highlands. It is, however, an animal that resists the progress of forest clearing much more 


successfully than the Canada lynx, and consequently may be looked for in many localities where the latter is no longer found.

Principal records. De Kay: "They are still found in the more northern and western counties in the wooded districts". ('42, p. 53). Merriam: "The wildcat is for some reason an extremely rare animal in the Adirondacks" ('82, p. 4I) Fisher: "It is probable that a few wildcats still remain in the wilder parts of the region. The last one killed in the neighborhood [of Sing Sing] as far as we know, was shot by a Mr Reynolds at Katonah. [Westchester co.] in March, I880" ('96, p. I98-99). Mearns: "On my last visit to the [Hudson] highlands in I 896 I saw no signs of the wildcat, and I was told that none had been killed there for several years past. During the first 25 years of my life the wildcat was at least as numerous as the red fox and more frequently killed. In the early seventies wildcats by their depredations caused so much loss to the residents of Putnam co., across the Hudson from my home, that bounties were privately subscribed by landowners amounting to $\$ 25$ for every one killed in that neighborhood. Mr Henry Le Farge still a hunter of local renown killed a considerable number of them, but there were still some wildcats remaining on Sugar Loaf mountain when I left the Highlands in 1884 ('98a, p. $35^{\mathrm{I}}$ ). Several stuffed specimens of wildcats said to have been killed in that neighborhood are preserved in the hotels and stores of the Catskills. It is in fact fairly common in these mountains " (' $98 \mathrm{~b}$, p. 359).

\section{Urocyon cinereoargenteus (Schreber) Gray fox}

1775 Canis cinereoargenteus Schreber, Säugethiere. pl. 92.

${ }_{78}{ }_{5}$ Canis vulpes $\Delta$ pennsylvanicus Boddaert, Elenchus Animalium.

I : 97. Based on the Brant Fox of Pennant.

I $8+2$ Vulpes virginianus De Kay, Zoology of New York, Mammalia.

p. 45 .

I 894 Urocyon cinereoargenteus Rhoads, American naturalist. June I894. $28: 524$.

1 896 Urocyon virginianus Fisher, The Observer. May 1896. 7: 199.

I898 Urocyon cinereoargenteus Mearns, Am. mus. nat. hist. Bul. 9 Sep. 1898 . ro: 350 .

I898 Urocyon cinereoargenteus Mearns, U. S. Nat. mus. Proc. $2 \mathrm{r}: 360$.

Type locality. North America.

Faunal position. The gray fox is a strictly austral animal.

Habitat. Woods, thickets, rocky hillsides and in fact all dry situations.

Distribution in New York. The gray fox enters New York with the unper austral fauna at the extreme west, in the Hudson valley and on Long Island. 
Principal records. De Kay: "This species is more common in the southern counties than farther north. On Long Island it is very abundant" ('42, p. 46). Fisher: "Not uncommon [at Sing Sing] but much rarer than the red fox. Judging from the number killed the red fox is five times more common than the gray" ('96, p. 199). Mearns: "This is the common fox of the [Hudson highlands] region, the red fox being comparatively scarce. It is very destructive to poultry" ('98a, p. 350). "A few gray foxes were said to have made their appearance in the upper part of Schoharie valley during recent years" ('98b, p. 36o).

I have never met with the gray fox in New York.

$\mathrm{Mr}$ Savage writes me that he has reliable evidence of the recent capture of several gray foxes near Buffalo.

Mr Helme writes: "The gray fox was formerly quite common on Long Island, but now it is nearly extinct. I have heard of no specimens taken during the past four or five years."

\section{Vulpes fulvus Desmarest Red fox}

I 820 Canis fulvus Desmarest, Mammalogie. p. 203

1842 Vulpes fulvus De Kay, Zoology of New York, Mammalia. p. 44. 1882 Vulpes vulgaris pennsylvanicus Merriam, Linn. soc. New York.

Trans. I : 45. (Not of Boddaert)

1896 Vulpes pennsylvanicus Fisher, The Observer. May I896. 7: 109. 1 898 Vulpes pennsylvanicus Mearns, U. S. Nat. mus. Proc. $21: 35^{8}$.

1898 Vulpes pennsylvanicus Mearns, Am. mus nat. hist. Bul. 9 Sep. 1898 . Iо : $35^{\circ}$.

Type locality. Virginia.

Fannal position. Upper austral, transition and Canadian zones.

Habitat. While its habitat is primarily forests the red fox can accommodate itself to an almost endless variety of conditions.

Distribution in New York. The red fox occurs throughout the state.

Principal records. De Kay: (No details given but the inference is that the author considered the animal well known everywhere in New. York). Merriam: "The common fox is a tolerably abundant resident in the north woods" ('82, p. 45). Fisher: Common [in the neighborhood of Sing Sing] ('96, p. 199). Mearns: "This splendid animal is not numerous in the [Hudson] highlands. It prefers more open country" ('98a, p. 350). "This fox is known to be tolerably common throughout the Schoharie valley" ('98 b, p. 358).

I have found the red fox not uncommon at Geneva, Ontario co.; Peterboro, Madison co. and Elizabethtown, Essex co. 

Mr Savage reports it not uncommon in Erie co.

"The red fox is plentiful in most sections of Long Island east of the township of Oyster bay" (Helme).

\section{Canis occidentalis (Richardson) Timber wolf}

I829 Canis lupus occidentalis Richardson, Fauna Boreali-Americana. I : 60 .

1842 Canis lupus De Kay, Zoology of New York, Mammalia. p. 42.

1882 Canis lupus Merriam, Linn. soc. New York. Trans. I : 42 .

I898 Canis mubilis Mearns, U. S. Nat. mus. Proc. 2 I :360.

I898 Canis occidentalis Bangs, American naturalist. July x 898. $32: 505$.

Type locality. Northern North America.

Faunal position. This animal is so imperfectly known that it is impossible to assign it a definite faunal position.

Habitat. Forests.

Distribution in New York. While the wolf formerly ranged throughout the state it is now exterminated everywhere except in the wildest parts of the Adirondacks.

Principal records. De Kay: "In some of the southern counties, where they were formerly so numerous as to require legislative enactments, they are now nearly extirpated ... They are still found in the mountainous and wooded parts of the state and we believe are most numerous in $\mathrm{St}$ Lawrence and the adjacent counties" ('42, p. 43).

Merriam: "Comparatively few wolves are now to be found in the Adirondacks, though 12 years ago they were quite abundant and used to hunt in packs of half a dozen or more . . . In September r870 I saw a pack of wolves drive a deer into the head of Seventh lake, Fulton chain . . . In the year 187 I the state put a bounty on their scalps, and it is a most singular coincidence that a great and sudden decrease in their number took place at about that time. What became of them is a great and to me inexplicable mystery, for it is known that but few were killed" ('82, p. 42-43).

Mearns: "It is generally believed that the last wolf disappeared from the Catskills along with the deer many years ago though one man expressed the belief that some still remain" ('98, p. 360).

In $182_{3}$ Pierce found the wolf still common in the Catskills. He believed that there were "two varieties,... one called the deer wolf from his habit of pursuing deer for which his light grey hound form adapts him. The other of a more clumsy figure with short legs and large body more frequently depredates upon flocks under the protection of man" ('23, p. 93). 
It is needless to say that there is very little probability that two forms of wolf have occurred in New York in historic times. Nevertheless Pierce's statement has its interest, for the prominence given it by Darwin in his Origin of species (p. $7 \mathrm{I}$ ) if for nothing else.

Remarks. The data which form the basis of the accompanying table of wolf bounties were furnished by Dr Frederick J. H. Merrill.

Table of bounties paid for wolves in New York under law of 1871

\begin{tabular}{|c|c|c|c|c|c|c|c|}
\hline \multicolumn{2}{|c|}{ County } & \multicolumn{2}{|l|}{ Town } & \multicolumn{2}{|c|}{ Date } & By whom killed & $\begin{array}{l}\text { Amount } \\
\text { paid }\end{array}$ \\
\hline Broome & e ...... & Barker .... & .... & $23 \mathrm{~F}$ & 1881 & B. H. Moak ............... & $\$ 30$ \\
\hline$\underset{66}{\text { Essex. }}$ & ( & Minerva.... & $\ldots .$. & $6 \mathrm{~S}$ & 1872 & Wesley Rice ......... & $\begin{array}{l}30 \\
30\end{array}$ \\
\hline$\therefore \quad$ & ....... & " $\quad \ldots$ & ..... & $25 \mathrm{Jl}$ & 1885 & Samuel Wilson........ & 30 \\
\hline Frankli & lin.... & Brandon ... & $\ldots . .$. & $12 J \mathrm{e}$ & 1875 & Calvin Wait .......... & 30 \\
\hline "6 & $\ldots .$. & 6 $\quad \ldots$ & ..... & $17 \mathrm{Je}$ & 1875 & "6 $\quad \ldots \ldots \ldots \ldots$ & 30 \\
\hline "6 & .... & Duane .... & $\ldots . .$. & $4 \mathrm{Jl}$ & 1874 & J. H. Вeau ............ . & 30 \\
\hline Fultou. & $1 \ldots \ldots$. & Bleecker... & $\ldots .$. & $10 \mathrm{Ap}$ & 1895 & E. Kosobuske ......... & 30 \\
\hline Hamilt & ton $\ldots$ & Long Lake. & ...... & 28 Mar & 1882 & Peter Fahlgren ....... & 30 \\
\hline 6 & & 7. & $\ldots . .$. & $1 \mathrm{Ap}$ & 1882 & .6 $6 \quad \ldots \ldots$ & 30 \\
\hline 6. & $\ldots$ & "6 & ...... & $27 \mathrm{~S}$ & 1882 & George Muir .......... & 30 \\
\hline 66 & & 16 & ...... & 25 Mar & 1883 & $\begin{array}{cc}66 & \ldots \ldots\end{array}$ & 30 \\
\hline 6 & $\ldots$ & 66 & $\ldots .$. & 17 Ja & 1887 & J. H. Higbey . . . . . . . . . & 30 \\
\hline 6 & $\ldots$ & Wells ...... & ..... & $16 \mathrm{Mar}$ & 1883 & Peter Decker.......... & 30 \\
\hline 6 & & "6 $\quad \ldots .$. & 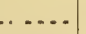 & "6 & & $66 \quad \ldots \ldots \ldots$ & 30 \\
\hline Herkim & ner .... & Olıio $\ldots . .$. & $\ldots+\ldots$ & $28 \mathrm{Ja}_{\text {، }}$ & 1882 & Henry $_{66}$ Sheldon ........ & $\begin{array}{l}30 \\
30\end{array}$ \\
\hline "6 & $\ldots$. & Wilmurt ... & (n) & 8 J1 & 1883 & George Muir ............. & 30 \\
\hline Lewis. & ........ & Batehfordvi & ille... & $10 \mathrm{~N}$ & 1881 & Frank Riley ........ & 30 \\
\hline 66 & $\ldots \ldots$. & Diana ..... & ..... & $2 \pi \mathrm{Je}$ & 1882 & George Muir .......... & 30 \\
\hline 6 & $\ldots \ldots$ & $\because \quad \ldots \ldots$ & $\ldots .$. & $27 \mathrm{Ap}$ & 1884 & $\because \quad \quad \ldots \ldots \ldots \ldots$ & 30 \\
\hline 16 & ........ & $\ldots$. & $\ldots .$. & $10 \mathrm{My}$ & 1895 & $\ldots \ldots \ldots$ & 30 \\
\hline 66 & ........ & ..... & ..... & $18 \mathrm{My}$ & 1895 & $\ldots \ldots \ldots$ & 30 \\
\hline "6 & ........ & ..... & $\ldots . .$. & $18 \mathrm{Ap}$ & 1896 & $\ldots \ldots$ & 30 \\
\hline "6 & . & ..... & ...... & $16 \mathrm{~s}^{1}$ & 1896 & $\ldots \ldots$ & 30 \\
\hline 6 & ......... & ..... & ...... & 220 & 1896 & $\ldots$ & 30 \\
\hline 66 & ....... & .... & $\ldots . .$. & $20 \mathrm{I}$ & 1896 & $\ldots$ & 30 \\
\hline 66 & ....... & .... & ...... & $7 \mathrm{Ja}$ & 1897 & $\ldots . .$. & 30 \\
\hline 66 & ........ & .... & $\ldots$ & $31 \mathrm{Mr}$ & 1897 & $\ldots . . .$. & 30 \\
\hline$"$ & & ..... & $\ldots .$. & $5 \mathrm{Ag}$ & 1897 & ...... & 30 \\
\hline "6 & & " $\quad \ldots$ & ...... & $23 \mathrm{~S}^{\circ}$ & 1897 & $66 \quad \ldots \ldots$ & 30 \\
\hline "6 & $\ldots$ & Greig ..... & ...... & $10 \mathrm{~N}$ & 1881 & George Botehford ... & 30 \\
\hline or & ........ & Lyousdale. & …. & 40 & 1882 & 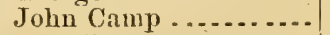 & 30 \\
\hline 6 & $\ldots \ldots$. & " $6, \ldots$ & $\ldots .$. & 130 & 1882 & . $6610.6 \ldots$ & 30 \\
\hline 6 & $\ldots \ldots$. & & -..... & $17 \mathrm{~N}$ & 1882 & $66 \quad \ldots \ldots \ldots \ldots$ & 30 \\
\hline 16. & & $6 . \quad \ldots$ & -..... & $15 \mathrm{D}$ & 1882 & Thowas Lee .......... & 30 \\
\hline Oneida & a....... & Floyd .... & ...... & $8 \mathrm{~F}$ & 1886 & IV. A. \& I. E. Bennett. & 30 \\
\hline 6 & & Forestport. & ...... & $14 \mathrm{~F}$ & 1882 & Henry Durrin......... & 30 \\
\hline$\because$ & $\ldots \ldots \ldots$ & $66^{2}$ & $\ldots .$. & $15 \mathrm{Mar}$ & 1882 & 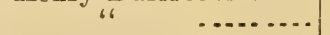 & 30 \\
\hline 6 & $\ldots \ldots$ & "6 & & 19 Mar & 1882 & 6 $\quad \ldots \ldots$ & 30 \\
\hline 6 & $\ldots . .$. & $"$ & & $2 \mathrm{Ap}$ & 1882 & Daniel Rodgers ....... & 30 \\
\hline$"$ & $\ldots$. & " & & $9 \mathrm{Ap}$ & 1882 & a if $10 . \ldots$ & 30 \\
\hline 66 & & 6 & & $140^{2}$ & 1882 & $\begin{array}{l}\text { Henry Durrin \& S. L. } \\
\text { Fones............... }\end{array}$ & 30 \\
\hline 16 & & 66 & & 190 & 1882 & $\begin{array}{l}\text { Henry Dumin \& S. L. } \\
\text { Fones ............... }\end{array}$ & 30 \\
\hline "6 & & 66 & & & & Henry Durrin........ & 30 \\
\hline Otsego & & Plaiufield . . & $\ldots . .$. & $14 \mathrm{~F}$ & 1888 & J. D. Wilkinson....... & 30 \\
\hline
\end{tabular}




Table of bounties paid for wolves in New York under law of 1871, conlinued

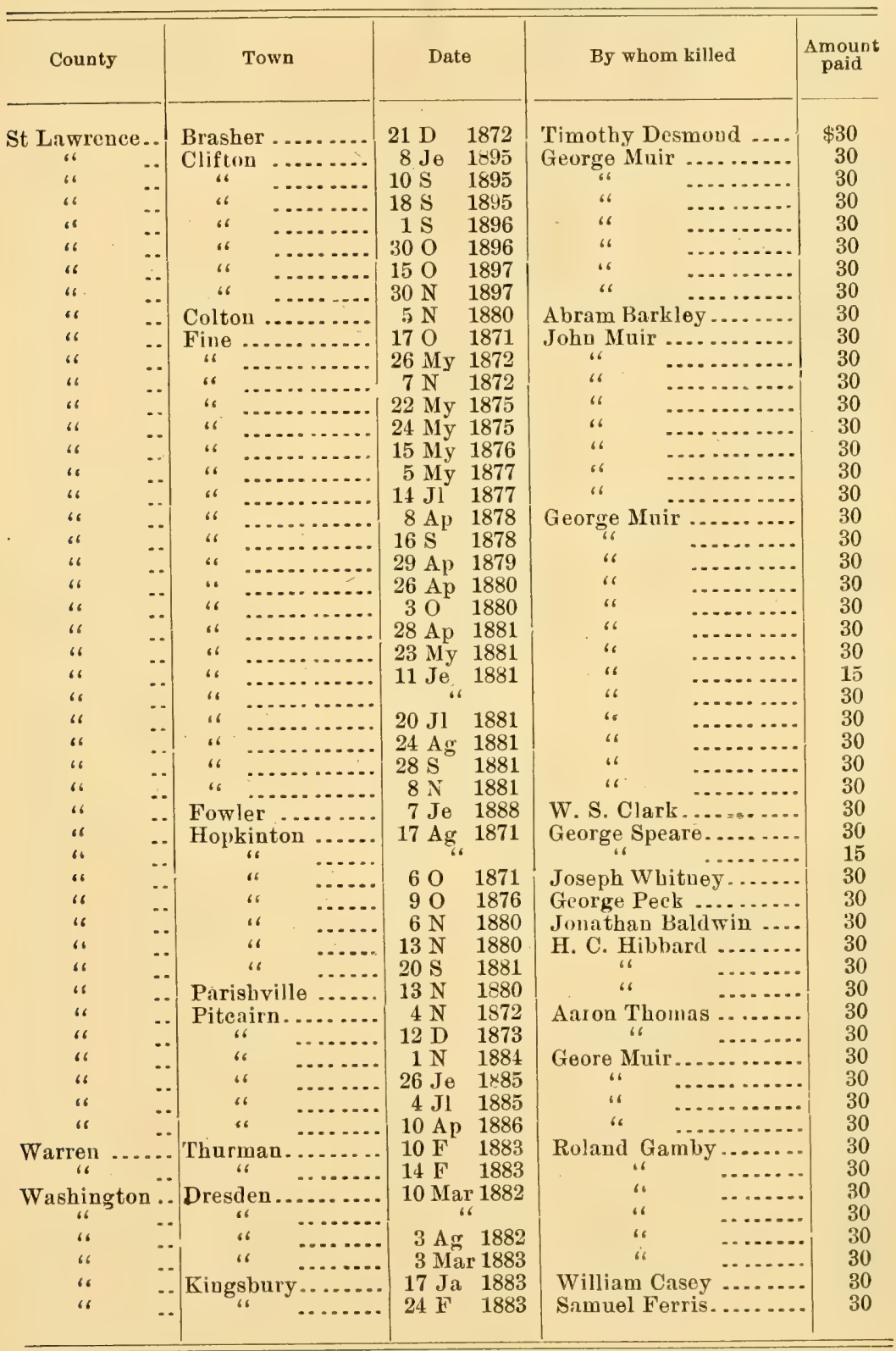


Summary by counties

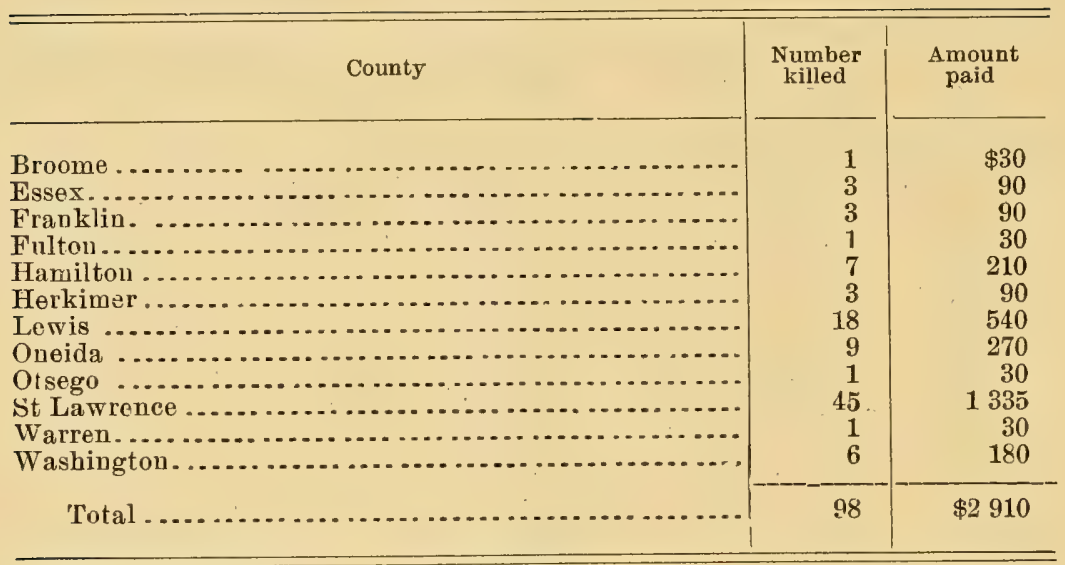

Summary by years

\begin{tabular}{|c|c|c|}
\hline Year & $\begin{array}{l}\text { Number } \\
\text { killed. }\end{array}$ & $\underset{\text { paid }}{\text { Amount }}$ \\
\hline 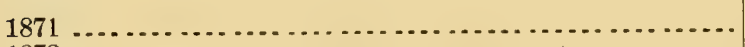 & 4 & $\$ 105$ \\
\hline 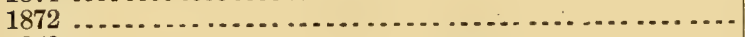 & 6 & 180 \\
\hline 1873 & 1 & 30 \\
\hline 1874 & 1 & 30 \\
\hline 2875 ... & 4 & 120 \\
\hline 1876 & 2 & 60 \\
\hline 1877 . & 2 & 60 \\
\hline 1878 . & 2 & 60 \\
\hline 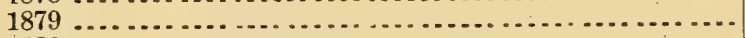 & 1 & 30 \\
\hline 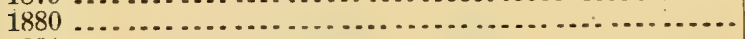 & 6 & 180 \\
\hline 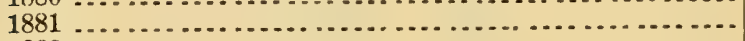 & 12 & 315 \\
\hline 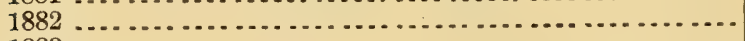 & 21 & 630 \\
\hline 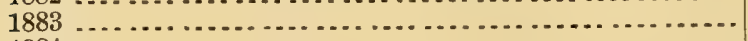 & 9 & 270 \\
\hline 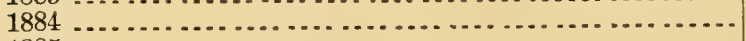 & 2 & 60 \\
\hline 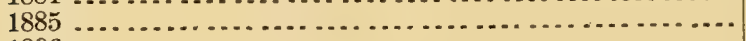 & 2 & 60 \\
\hline 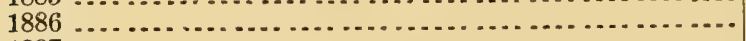 & 2 & 60 \\
\hline 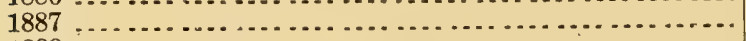 & 1 & 30 \\
\hline 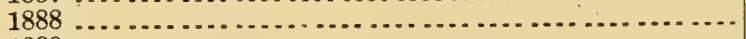 & 2 & 60 \\
\hline 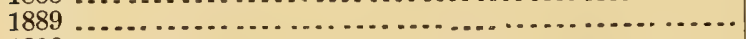 & 0 & $\ldots \ldots \ldots$ \\
\hline 1890 . & 0 & ........ \\
\hline $1891 \ldots \ldots \ldots$ & 0 & ........ \\
\hline 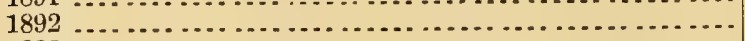 & 0 & ........ \\
\hline 1893 . & 0 & ........ \\
\hline 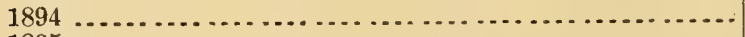 & 0 & $\ldots . . . .$. \\
\hline 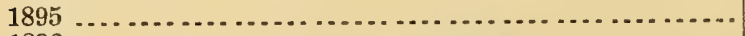 & 6 & 180 \\
\hline $1896, \ldots \ldots \ldots \ldots \ldots$ & 6 & 180 \\
\hline 1897 . & 6 & 180 \\
\hline 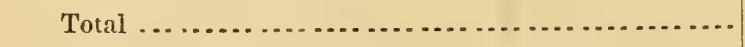 & 98. & $\$ 2910$ \\
\hline
\end{tabular}






\section{Ursus americanus Pallas Black bear}

1780 Ursus americanus Pallas, Spicilegia zoologica. Fasc. I4: 5.

1842 Ursus americamus De Kay, Zoology of New York, Mammalia. p. 42.

1882 Ursus americanus Merriam, Linn. soc. New York. Trans. r:95. 1898 Ursus americanus Mearns, U. S. Nat. mus. Proc. 2 I : 357.

Type locality. North Carolina.

Fannal position. The geographic variations of the black bear are so imperfectly known that it is impossible to tell at present over what zones the form found in New York extends.

Habitat. Forests.

Distribution in Nere York. The black bear is now exterminated throughout the state except in the region of the Adirondacks and Catskills. •

Principal records. De Kay: "The bear, once so numerous . in this state, is now chiefly to be found in the mountainous and thinly inhabited districts" - ('42, p. 24). Merriam : "This ... mammal ... is still abundant in most parts of the wilderness" ('82, p. 95). Mearns: "Though still common in the Adirondack and Catskill mountains the bear disappeared from the [Hudson] highlands many years ago though my father's mother saw them there (' $\left.98 \mathrm{a}, \mathrm{p} .35^{2}\right)$. I saw recent signs of bears on Plateau mountain, in August, I 896 . Several bears were killed a few miles south of the mountain during the same month . . . This species is far from being exterminated in the Catskills" ('98b, p. 357).

\section{Lutra canadensis canadensis (Schreber) Northeastern otter} I 776 Mustela hutra canadensis Schreber, Säugethiere. 3 : pl. г26 B. I 803 Mustela hudsonica Desmarest, Nouv. dict. d'hist. nat. I $3: 384$. 183 r Liitra hudsonica F. Cuvier, Suppl. Oeuvres de Buffon. I : 194. I842 Lutra canadensis De Kay, Zoology of New York, Mammalia.

$$
\text { p. } 39 \text {. }
$$

I882 Lutra canadensis Merriam, Linn. soc. New York. Trans. I :87. 1896 Lutra canadensis Fisher, The Observer. May I896. $7:$ 199. 1898 Lutra hudsonica Mearns, Am. mus. nat. hist. Bul. 9 Sep. I898. $10: 347$.

r898 Lutra hudsonica Mearns, U. S. Nat. mus. Proc. $21: 360$.

Type locality. Eastern Canada.

Faunal position. Boreal and transition zones.

Habitat. Borders of lakes, rivers, streams and marshes. 
Distribution in New York. While the otter has doubtless greatly decreased in numbers during the present century it probably still occurs throughout the greater part of New York. Details of its present distribution are however wholly lacking.

Principal records. De Kay: "The American otter, once so numerous in every part of the state, is now exceedingly scarce. In the counties of Kings, Queens, Suffolk and Richmond it is now extirpated. In the northern districts it is yet sufficiently numerous to become an object of pursuit" (' 42, p. 40). Merriam: "The otter is a common inhabitant of the Adirondacks" (' 82, p. 87). Fisher: "Probably it still rarely occurs at Croton lake and river. The last specimen we have any record of was taken in the tide creeks in Croton point about 1880 " ('96, p. r99). Mearns: "Otters are still found in the Hudson and in the streams and lakes of the Highlands though the species has now become extremely scarce. 20 years ago it was more numerous" ("98a, p. 347). "Otters were sáid by one or two of the Catskill residents to have been taken occasionally along Schoharie creek and at Kaaterskill lake during the past 25 years" ( $98 \mathrm{~b}, \mathrm{p} .360)$.

Mr Helme writes that the otter is nearly if not quite extinct on Long Island.

Remarks. It is possible that the otter of the Hudson highlands and Long Island is the southeastern otter Lutra hudsonica lataxina (F. Cuvier) recently distinguished from the northern form by Rhoads (' $98 \mathrm{c}$, p. 420 ).

\section{Mephitis mephitica (Shaw) Skunk}

1792 Viverra mephitica Shaw, Museum Leverianum. p. I72.

1842 Mephitis americana De Kay, Zoology of New York, Mammalia. p. 29.

$185^{8}$ Mephitis mephitica Baird, Mamm. N. Am. p. 195.

I882 Mephitis mephitica Merriam, Linn. soc. New York. Trans. I : 69. г896 Mephitis mephitica Fisher, The Observer. May г896. 7 : 199.

I 898 Mephitis mephitica Mearns, U. S. Nat. mus. Proc. $2 \mathbf{1}: 35^{8}$.

r898 Mephitis mephitica Mearns, Am. mus. nat. hist. Bul. 9 Sep. 1898 . $10: 35$.

Type locality. North America.

Faunal position. Until the exact status of the skunks found in New York is better understood it will be impossible accurately to state their faunal position.

Habilat. Woods, fields and in fact anywhere, provided the ground is dry enough for burrowing. 


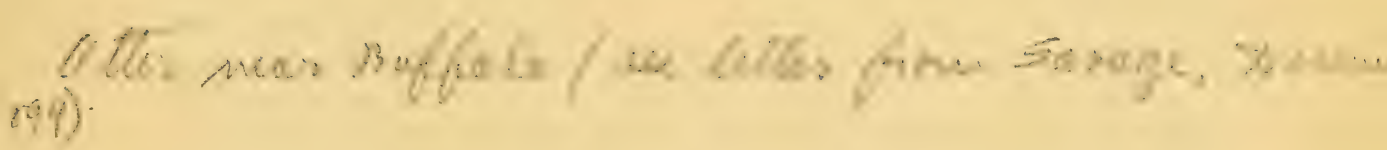



Distribution in Neze York. The skunk occurs throughout the state. This is probably an animal whose range has been slightly if at all affected by the removal of the forests, but which has undoubtedly increased in numbers with the transformation of forests into farms.

Principal records. De Kay: "This well known and thoroughly detested animal is supposed to exist throughout the whole American continent" ('42, p. 30). Merriam: "The skunk is very common in the clearings and settled districts bordering this region and is found sparingly throughout the Adirondacks" ('82, p. 69). Fisher: "Common [at Sing Sing]. A very beneficial animal and one that should be carefully protected" ('96, p. I99). Mearns: "Common. Three specimens were trapped on the banks of Schoharie creek. It was not met with on the mountains" ('98b, p. 358).

I have found the skunk common at Geneva, Ontario co. and at Peterboro, Madison co.

Of the presence of the animal in the neighborhood of Buffalo $\mathrm{Mr}$ Savage writes: "The skunk is common, occasionally coming into the heart of the city. About three winters ago I came upon five dead skunks in ro days all within a radius of three-quarters of a mile and all within the city limits. Last fall a friend dug out a rabbit that his dog had 'holed,' and found that in the short time occupied by the work of excavation the animal had been killed and partly eaten by a skunk that happened to be occupying the hole." Mr Helme says: "The skunk is common but for some unknown reason it is much less numerous than formerly."

Remarks. It is probable that the skunk of the upper austral areas in New York is subspecifically distinct from that occurring in the Canadian zone, but at present there is no material with which to decide the question. If there are two forms the Canadian animal is Mephitis mephitica mephitica, the upper austral, M.mephitica scrutator Bangs. The ranges of these subspecies are given by Bangs as follows: $M$. mephitica mephitica, "Boreal eastern North America; Nova Scotia, Quebec, and Ontario south to about the northern limits of the United States" ('96d, p. I40); $M$. mephitica scrutator, "Pine and prairie regions of central Louisiana, extending up the Mississippi valley to Indiana and eastward across the Alleghanies to Virginia and thence northward, gradually becoming less typical until it merges into true mephitica" ('96d, p. 14I).

It is of interest to note that De Kay in speaking of this animal now so extensively trapped for its fur says: "His fur is coarse and of no value as an article of commerce" ('42, p 30 ). 


\section{Gulo luscus (Linnaeus) Wolverine}

I $75^{8}$ Ursus luscus Linnaeus, Syst. nat. ed. Io. I : 47 .

I823 Gulo luscus J. Sabine, Franklin jour. p. 650.

I842 Gulo luscus De Kay, Zoology of New York, Mammalia. p. 27. I882 Gulo luscus Merriam, Linn. soc. New York. Trans, I : 47 .

Type locality. Hudson bay.

Faunal position. Boreal and transition zones.

Habitat. Forests.

Distribution in New York. While the wolverine has within historic times ranged throughout the state it is now wholly exterminated.

Principal records. De Kay: "Although we have not met with this animal yet hunters who have killed them repeatedly and knew them well have assured us that they are still found in the districts north of Raquet lake. It is however everywhere a rare species" ('42, p. 28). Merriam: "The wolverine (Gulo luscus) is not now an inhabitant of the Adirondacks, and I have been unable to find among the hunters and trappers of this region anyone who has ever seen it in our wilderness" ('82, p. 47-48). Bachman states (Audubon and Bachman, '46, I : 207-8) that about the year I8I I he killed a wolverine in Rensselaer co.

Putorius vison vison (Schreber). Northeastern mink

1778 Mustela vison Schreber Säugethiere. 3:463.

I830 Putorins vison Gapper Zool. jour. 5:202.

1853 Putorius nigrescens Audubon and Bachman Quadr. N. Am. $3: 104$.

I882 Putorius vison Merriam Linn. soc. New York. Trans. I : 64 .

I 896 Putorius vison Bangs Boston soc. nat. hist. Proc. 27:3.

I 898 Putorius vison Mearns U.S. Nat. mus. Proc. $21: 35^{8}$.

Type locality. Canada.

Faunal position. Hudsonian and Canadian zones.

Habitat. Borders of lakes, ponds and water courses.

Distribution in Nere York. The northeastern mink is not found in New York outside of the Adirondacks and Catskills.

Principal records. Merriam: "The mink is a well-known and tolerably abundant inhabitant of this region ('82, p. 64). Mearns: "This small mink is common on all the streams of the neighborhood [Catskill $\mathrm{mts}$ ] and at Kaaterskill lake" (' $98 \mathrm{~b}$, p. 358).

Putorius vison lutreocephalus (Harlan). Southeastern mink I825 Mustela hutreocephala Harlan, Fauna Americana. p. 63. r 842 Putorius vison De Kay, Zoology of New York, Mammalia. p. 37. 


ז896 Putorius vison lutreocephalus Bangs, Boston soc. nat. his. Proc. March $1896.27: 4$.

1896 Lutreola vison Fisher, The Observer. May r896. 7: r99.

I898 Putorius (Lutreola) vison lutreocephalus Mearns, Ain. mus. nat. hist. Bul. 9 Sep. 1898 . Iо: 347 .

Type locality. Maryland.

Faunal position. Transition zone and upper austral zone.

Habitat. Borders of lakes, ponds and water courses.

Distribution in New York. The southeastern mink occurs throughout the central and southern part of the state except in the Catskills where it is replaced by the northeastern form. The limits of distribution of both subspecies are however understood in a general way only.

Principal records. De Kay: "The mink is a well-known animal in every part of the state. Its popular name is corrupted from mank given to it by our early Swedish colonists" ('42, p. $\left.3^{8}\right)$. Fisher: "Common along all the larger streams and ponds [in the vicinity of Sing Sing]" ('96, p. I99). Mearns: "Minks have 'always' been rather common in this vicinity [the Hudson highlands]" ('98a, p. 347).

Mink are tolerably common at Peterboro, Madison co., but I am unable to determine the exact status of the form that occurs there. It is probably not exactly typical of either subspecies.

Mr Savage writes that: "The mink is very common in swamps and along streams in Erie co. I am inclined to think that the form found here is intermediate between typical vison and the subspecies lutreocephahus. Recently I examined two mink in the flesh which measured respectively $559 \mathrm{~mm}$ and $582 \mathrm{~mm}$ in total length."

According to Mr Helme the southeastern mink is not uncommon on Long Island.

Remarks. The forms of mink that occur in New York are much in need of critical revision but material for such study is lacking. In Bangs's paper on the mink ('96a) Putorius vison litreocephahis is referred to as an Atlantic coast form. Its range into the interior doubtles $s$ includes the whole of the area in New York occupied by the transition and upper austral zones, but proof of the correctness of this supposition is much to be desired.

Putorius cicognanii (Bonaparte) Bonaparte's weasel

I 838 Mustela cicognanii Bonaparte, Charlesworth's magazine. Jan. I $838 . \quad 2: 37$.

I839 Putorius cicognanii Richardson, Zool. Beechey's Voyage of the Blossom. p. xо. 
I842 Mustela pusilla De Kay, Zoology of New York, Mammalia. p. 34. r842 Mustela fusca De Kay, Zoology of New York, Mammalia. p. 35. 1882 Putorius vulgaris Merriam, Linn. soc. New York. Trans. I : 54. I896 Putorius richardsoni cicognanii Bangs, Biolog. soc. Washington, Proc. 25 Feb. 1896 . го: 18.

I896 Putorius cicognanii Merriam, North American fauna. no. Ir. 3o June 1896 . p. $\mathbf{\text { o. }}$

1 898 Putorius cicognanii Mearns, Am mus. nat. hist. Bul. 9 Sep. 1898. I o : 349 .

I898 Putorius cicognanii Mearns, U. S. Nat. mus. Proc. 2 I: $35^{8}$.

Type locality. Eastern United States.

Faunal position. Hudsonian, Canadian and transition zones.

Habitat. Woods and thickets.

Distribution in New York. Bonaparte's weasel occurs through the entire state, with the possible exception of the upper austral areas. These however are so narrow that they might readily be penetrated by a roving animal like a weasel, Bangs ('96a, p. I9) records it from Long Island.

Principal records. De Kay: "It is by no means a rare animal but is difficult to capture" ('42, p. 35). Merriam: "It is the commonest weasel in the Adirondack region" ('82, p. 54). Mearns: "About the year I870 I trapped one or two of these little short tailed weasels on our place at Highland falls and I have seen a few of them since. It is probably quite uncommon" ('98a, p. 349). "One specimen, a male ... was trapped on the left bank of Schoharie creek, August 23, I896" (' $\left.98 \mathrm{~b}, \mathrm{p} .35^{8}\right)$.

This weasel is tolerably common at Peterboro, Madison co.

Of the occurrence of Bonaparte's weasel in Erie co. Mr Savage writes: "Have seen a single $P$. cicognani."

Remarks. The confusion of names applied to this animal for many years arose partly from the sexual variation to which the species is subject and partly from lack of a clear conception of the differences which separate it from the common stoat of Europe. The whole subject is thoroughly explained by Bangs ('96a, p. 20-2I) and Merriam ('96, p. 10).

Putorius noveboracensis Emmons New York weasel.

I840 Putorius noveboracensis Emmons, Rep. Quad. Massachusetts. p. 45 .

I842 Putorius noveboracensis De Kay, Zoolngy of New York. Mammalia. p. 36. 


I 854 Putorius agilis Audubon and Bachman, Quad. N. Am 3: 184.

1882 Putorius erminea Merriam, Linn. soc. New York. Trans. I : 56. 1896 Putorius noveboracensis Bangs, Biolog. soc. Washington, Proc. 25 Feb. 1896. 10: 13.

1896. Putorius noveboracensis Fisher, The Observer. May 1896. 7 : 199 . r 898 Putorius noveboracensis Mearns, Am. mus. nat. hist. Bul. 9 Sep. I888. Iо : 348 .

I 898 Putorius noveboracensis Mearns, U. S. Nat. mus. Proc. 2 I : $35^{8}$. Type locality. New York state.

Faunal position. Upper austral and transition zones and lowermost edge of Canadian zone.

Habitat. Woods and thickets.

Distribution in New York. Owing to the confusion that has long existed in regard to the identification of our weasels it is now difficult to tell the exact limits of the range of this species. The animal is probably to be found in all parts of the state with the exception of the depth of the boreal areas.

Principal records. De Kay: "Its geographic limits as yet are not settled. We suppose it to be a northern animal found as far south as Pennsylvania" ('42, p. 37). Merriam: "The ermine is a common resident" ('82, p. 56). Fisher: "Tolerably common" ('96, p. I99). Mearns: "One was seen at Evelyne Villa in August r896" ('98b, p. 358).

I have never met with this weasel in New York.

Mr Savage writes : "The New York weasel is common in Erıe co."

Of the New York weasel on Long Island Mr Helme writes: "This animal is common. Although $I$ have met with it several times in winter I have never seen a specimen in white pelage."

\section{Mustela americana Turton Marten}

1806 Mustela americana Turton, General system of nature. I : 60. I842 Mustela martes De Kay, Zoology of New York, Mammalia. p. 32. 1882 Mustela americana Merriam, Linn. soc. New York. Trans. I : 52. I898 Mustela americana Mearns, U.S. Nat. mus. Proc. 2 I : 360.

Type locality. North America.

Faunal position. Boreal zones, and perhaps transition zone also, though in eastern North America the animal is exterminated in the latter.

Habitat. Forests.

Distribution in New York. The marten is now confined to the wilder parts of the Adirondacks. 
Principal records. De Kay: "Its geographic range extends from the Atlantic to the Pacific" ('42, p. 34). Merriam: "The marten is a common resident of the dark evergreen forests of the Adirondacks, and hundreds of them are trapped here every winter for their fur" (' 82 , p. 52). Mearns: "Some of the residents assert that both the pine marten and the pekan, $M$. pennanti Erxleben, are still sometimes taken in the Catskills, others exclude the pekan, but say that the marten still exists" ('98b, p. 360).

\section{Mustela pennanti Erxleben Fisher}

1777 Mustela pennanti Erxleben, Syst. regn. anim. p. 470.

I842 Mustela canadensis De Kay, Zoology of New York, Mammalia. p. $3^{\text {r. }}$

I882 Mustela pennanti Merriam, Linn. soc. New York. Trans. I 48. I 898 Mustela pennanti Mearns, U. S. Nat. mus. Proc. 2 I : 360.

Type locality. Canada.

Faunal position. Boreal zone and probably transition zone also.

Habitat. Forests.

Distribution in New York. The fisher which formerly ranged through the greater part of the state is now confined to the wilder parts of the Adirondacks though it occasionally wanders outside of this region.

Principal records. De Kay: "The fisher or black cat of our hunters, is a large and powerful animal, standing nearly a foot from the ground. It was formerly very abundant in this state, but is now confined to the thinly settled northern district. Twenty years ago they were numerous in the western part of the state, where they are now scarcely ever seen" ('42, p. $3^{\mathrm{I}-3^{2}}$ ). Merriam: "Though not so common as formerly, the fisher . . . is by no means a rare inhabitant of these [Adirondack] mountains" ('82, p. 48). Mearns: (see under Mustela americana).

Of the occurrence of this animal in Erie co. Mr Savage writes: "The fisher was probably common in this region before it was trapped out and the forests destroyed. In March, I889, a fisher was killed after being found under a lumber pile near the Niagara river and in the city of Buffalo. It was mounted by Miss Mathilde Schlegel now of East Aurora, New York."

\section{Procyon lotor Linnaeus Raccoon}

I $75^{8}$ [Ursus] lotor Linnaeus, Syst. nat. ed. 10. I $: 48$.

I 780 Procyon lotor Storr, 'Prodr. Meth. Mamm:'

I842 Procyon lotor De Kay, Zoology of New York, Mammalia. p. 26. 


1882 Procyon lotor Merriam, Linn. soc. New York. Trans. r :9I. 1896 Procyon lotor Fisher, The Observer. May 1896. 7:200. I 898 Procyon lotor Mearns, U. S. Nat, mus. Proc. 2 I : 357.

Type locality. Northeastern United States.

Fannal position. Austral zones, transition zone and southern border of Canadian zone.

Habitat. Forests.

Distribution in New York. The raccoon occurs throughout the state. It is probably one of the mammals whose range has been very little changed by the clearing of the country.

Principal records. De Kay: "The raccoon is found all over North America" ('42, p. 27). Merriam: "Raccoons are common everywhere about the borders of the Adirondacks, but they do not like dense evergreen forests and are therefore rather rare in the interior, still they are occasionally met in all parts of the wilderness" ('82, p. 9r). Fisher: "Common [near Sing Sing]. Found everywhere but more commonly in the swamps and along streams" ('96, p. 200). Mearns: "Tracks of the raccoon were seen in several places on or near Schoharie creek" ('98, p. 357).

I have found the raccoon common at Peterboro, Madison co.

Mr Savage writes: "The raccoon is common in Erie co."

Of this animal Mr Helme writes: "The raccoon is still quite common in most of the less thickly settled districts of Long Island."

\section{Phoca vitulina Linnaeus "Harbor seal}

I $75^{8}$ [Phoca] vitulina Linnaeus, Syst. nat. Ed. го. I : 38 .

I 842 Phoca concolor De Kay, Zoology of New York, Mammalia. p. 53. I 882 Phoca vitulina Merriam, Linn soc. New York. Trans. I : I04. 1896 Phoca vitulina Fisher, The Observer. May 1896. 7:200 I898 Phoca vitulina Mearns, Am. mus. nat. his. Bul. 9 Sep. I898. ro: 346 .

Type locality. Coast of Europe.

Distribution in New York. The harbor seal occurs regularly in Long Island sound and in the lower Hudson river. It also reaches the northern border of the state by way of the St Lawrence river, and on one occasion an individual penetrated as far into the interior as Onondaga lake.

Principal records. De Kay: "They are now comparatively rare in our waters, but were formerly very abundant . . . At some seasons even at the present day they are very numerous, particularly about the Execution 
rocks in the sound, but their visits appear to be very capricious" ('42, p. 54).

Merriam: "The harbor seal breeds regularly both in the Gulf and River of St Lawrence and I have seen numbers of them in July as far up the river as the Saguenay, and they are still common even within $5^{\circ}$ miles of Quebec."

"Zadock Thompson has recorded the capture of two of them on Lake Champlain ['42, p. 38].

"During a recent visit to Lake Champlain I was told that a seal had been killed on the ice near Crown point within four or five years but was unable to authenticate the statement.

"Dr. De Kay mentioned the occasional occurrence of this species on Lake Ontario, many years ago, and during the past winter one was killed on Onondaga lake that must have reached this remote inland water by way of Lake Ontario. [Syracuse Standard, '82].

"I have seen many of these seals in Long Island sound chiefly about the Thimble islands, and March 25, I879, I saw one on a rock in the Hudson river near Sing Sing" ('82, pp. 104-5).

Fisher: "Almost every spring one or more seals are seen [near Sing Sing] about the time the ice is breaking up in the river. On March II, I884, an adult male was secured in the cove" ('96, p. 200).

Mearns: "The seal has been seen several times and once captured in the Hudson highlands. One was shot at New Hamburg on the Hudson by a $\mathrm{Mr}$ Wood for whom the specimen was mounted by $\mathrm{Mr}$ James S. Buchanan, a taxidermist of Newburgh who showed me the specimen and four large jars of oil which he took from it. It was shot on the ice near an airhole in the river in midwinter $1877-78$ and weighed 60 pounds" ('98a, p. 346).

For other records of the harbor seal in or near New York waters see Fisher ' 84 , Merriam ' $84 \mathrm{a}$ and ' $84 \mathrm{C}$ and Syracuse Standard' 82 .

Mr Helme writes, "A few harbor seals are met with each winter along the rocky shores of the eastern part of Long Island. Occasionally they are found in the sound."

\section{Cystophora cristata (Erxleben) Hooded seal}

I 777 Phoca cristata Erxleben, Syst. regn. anim. p. 590.

I84 I Cystophora cristata Peters, Wiegmann's Archiv für Naturgeschichte, 7 ter Jahrg. Bd. $x: 326$.

1842 Stemmatopus cristatus De Kay, Zoology of New York, Mammalia. p. 55 . 


Type locality. Southern Greenland.

Faunal position. Arctic zone.

Habitat. Ice floes and sea coasts.

Distribution in New York. The hooded seal has been taken in New York on one occasion only. It is a mere straggler to the coast of the United States; though it has been known to wander as far south as Chesapeake bay (Allen, ' 8o, p. 737).

Principal records. De Kay: "This description was taken from an adult male captured near Eastchester about ${ }_{5} 5$ miles from the city " ('42, p. $\left.5^{6}\right)$.

Remarks. For an account of the 'hood' of this animal see Merriam, '84b.

\section{-Serex albibarbis (Cope) Water shrew}

1862 Neosorex albibarbis Cope, Acad. nat. sci. Philadelphia. Proc. p. 188.

I 892 Sorex albibarbis Merriam, Biolog. soc. Washington. Proc. $7: 25$. 1894 Sorex albibarbis Miller, Boston sci. nat. hist. Proc. $26: 183$. 1895 Sorex albibarbis Miller, North American fauna, no. го. p. 46.

Type locality. Profile lake, New Hampshire.

Faunal position. Boreal zone.

Habitat. Marshes, wet woods and the margins of streams and ponds.

Distribution in New York. The water shrew has been only once recorded from New York (Miller, '94, p. 47). Although it has not yet been found outside of Essex co. the animal doubtless ranges throughout the Adirondacks. It will probably be found in the Catskills as well as in other localities where the fauna is largely composed of boreal forms. Rhoads has taken the water shrew in Pike co. Pa. ('95a, p. 395).

\section{Sorex fumeus Miller Smoky shrew}

1884 Sorex platyrhinus Merriam, Linn. soc. New York. Trans. 2:77 (not Otisorex platyrhinus De Kay).

I895 Sorex fumeus Miller, North American fauna. no. Io. $3 \mathbf{r}$ Dec. I895. p. 50.

I898 Sorex fumeus Mearns, U. S. Nat. mus. Proc. $2 \mathrm{I}: 354$.

Type locality. Peterboro, Madison co. New York.

Fannal position. Boreal zone and cooler parts of transition zone.

Habitat. Heavy woods and forests.

Distribution in New York. The range of the smoky shrew in New York coincides very closely with that of the common red-backed mouse and the Canadian white-footed mouse. The animal is abundant 
throughout the heavily forested boreal area in the northern part of the state. South of this region it occurs in isolated colonies wherever local conditions give it a sufficiently boreal environment.

Principal records. Merriam: "This species . . is not rare in the Adirondacks though I do not think it is as plentiful here as Sorex cooperi [personatus], which it much resembles in habits" ('84d, p. 77). Mearns: "Three specimens were taken [in the Catskills]. One was trapped under a stone wall on the right [north] bank of Schoharie creek, one in a hollow stump on the south slope of East Jewett mourtain at about 2000 feet altitude, and the third under a $\log$ a little farther up the mountain" ('98b, p. 354).

I have found the smoky shrew at Peterboro and Chittenango falls, Madison co. and at Elizabethtown, Essex co. ('95, p. 50.52). At the type locality it is local and not common. Most of the specimens including the type were trapped in a gorge on the Oneida creek about three miles southwest of the village of Peterboro. At Elizabethtown it is common and very generally distributed in the forests.

Remarks. This species will probably be found in many localities in New York. Rhoads has recolded it from the following counties in Pennsylvania: Pike, Monroe, Sullivan, Clinton, Columbia and Somerset ('97b, p. 223).

Sorex macrurus Batchelder Big-tailed shrew

ז896 Sorex macrumus Batchelder, Biolog. soc. Washington. Proc. 8 Dec. 1896 . 1о: 33 .

I 898 Sorex macrurus Mearns, U. S. Nat. mus. Proc. $2 \mathrm{I}: 355$.

Type locality. Beedes, Essex co. New York.

Fannal position. The big-tailed shrew is so slightly known that I am unable to assign it a definite faunal position. In all probability it is confined to the colder parts of the boreal zone.

Habitat. (See principal records).

Distribution in New York. The only localities at which this animal has been taken are Beedes, the summit of Mt Marcy and the Catskills. In all only ro specimens have yet been collected.

Principal records. Batchelder: "On September 9, 1895 at Beedes, Essex co. New York I obtained a shrew unlike any species known to me. It was caught . . among some large angular rocks at the head of a wooded talus of loose rock. Just above, shading the spot and keeping it moist and cool, rise the low cliffs from whose fragments the talus has been formed. 


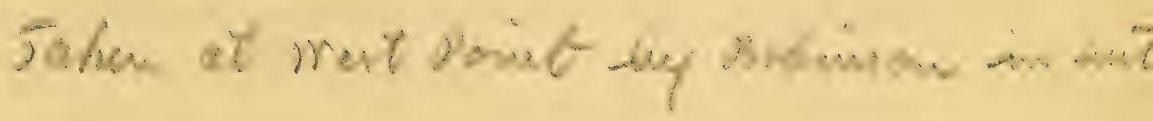



"Nearly a year later on August i, I896 I caught a second specimen of this shrew on Mt Marcy, the highest of the Adirondack mountains . . . It was taken in a crevice between some rocks on the bare open summit of the mountain about 5300 feet above sea-level. The locality where the first one was captured is about eight miles distant in an air line and lies at an elevation of only I300 feet above the sea" ('96b, p. I33).

Mearns: "The [eight] specimens were trapped in hollows under mossy stones and stumps usually in wet balsam or spruce woods or in weedy swamps. The lowest place where it was taken was in a balsam swamp at about 3700 feet altitude, others were caught somewhat higher in a sparsely wooded swamp densely overgrown with asters (Aster punicens) then in bloom, and four were trapped on the top of Hunter mountain (altitude 4025 feet)" ('98b p. 356).

\section{Sorex personatus I. Geoffroy St Hilaire Masked shrew}

I827 Sorex personatus I Geoffroy St Hilaire, Mem. du mus. d'hist. nat. Paris. I $5:$ I 22.

I842 Sorex forsteri De Kay, Zoology of New York, Mammalia. p.40. 1842 Otisorex platyrhinus De Kay, Zoology of New York, Mammalia. p. 22.

I884 Srrex cooperi Merriam, Linn. soc. New York. Trans. $2: 75$. I895 Sorex personatus Miller, North American fauna. no. ro. 3 r Dec. I 895 . p. 53 .

1896 Sorex personatus Fisher, The Observer. May i 896.7 : 194 .

I 898 Sorex personatus Mearns, U. S. Nat. mus. Proc. 21 : 355 .

I 898 Sorex personatus Mearns, Am. mus, nat. hist. Bul. 9 Sep. I898. Io: 343 .

Type locality. Eastern United States possibly somewhere in New York.

Faunal position. Boreal and transition zones; cool localities in upper austral zone.

Habitat. Open or wooded places both wet and dry.

Distribution in New York. The masked shrew probably occurs throughout the state.

Principal records. De Kay: "They are found in all parts of the state" ('42, p. 2x). Merriam: "This diminutive shrew, the smallest. known mammalian inhabitant of the Adirondacks, is quite common in most parts of the region but much more abundant some years than others" ('84d, p. 75). Fisher: "The common shrew is rather rare and is the only one of the long-tailed species found in the neighborhood [of Sing Sing]. Its scarcity however may be only apparent and due wholly 
or in part to our lack of skill in former days in trapping it successfully" ('96, p. 194). Mearns: "Two specimens were trapped, the first . . . in a balsam swamp at 3700 feet altitude and the second . . . on the actual summit of Hunter mountain" ('98b, p. 355).

I have found the masked shrew common at Peterboro, Madison co. and Elizabethtown, Essex co. In both localities it is generally distributed.

Mr Savage writes: "Sorex personatus is abundant in the low flat land known as the 'Tifft farm' near Buffalo. Here I have frequently heard them squeaking all around me."

Of the masked shrew Mr Helme writes: "This diminutive mammal is not rare in most parts of Long Island. It builds a small spherical nest of dry leaves in some cavity under a $\log$ or old stump. I once found six specimens under an old $\log$ in a nest of leaves and bits of dry seaweed."

\section{Sorex hoyi Baird Hoy's shrew}

I8 8 Sorex hoyi Baird, Mamm. N. Am. p. 32 .

I895 Sorex hoyi Merriam, North American fauna. no. Io. 3I Dec. i895. p. 89 .

Type locality. Racine, Wisconsin.

Faunal position. Hoy's shrew is probably an inhabitant of the transition and boreal zones. Its faunal position is not well understood.

Habitat This animal is so little known that its habitat cannot be definitely stated. Apparently it is more often found in cleared land than in woods or forests (see Miller, 97 b, p. 37).

Distribution in New York. While this species probably occurs throughout the northern half of the state it has as yet been taken at Locust Grove, Lewis co. only (Merriam, '95, p. 9o).

\section{Blarina brevicauda (Say) Short-tailed shrew .}

1823 Sorex brevicaudus Say, Long's exped. to the Rocky mts.

I837 Sorex dekayi Bachman, Acad. nat. sci. Philadelphia. Jour. pt. 2. $7: 377$.

1842 Sorex dekayi De Kay, Zoology of New York, Mammalia p. I7 (part).

1842 Sorex brevicaudus De Kay, Zoology of New York, Mammalia. p. 18 (part).

1842 Sorex carolinensis De Kay, Zoology of New York, Mammalia. p. 2 I (part). 


r $85^{8}$ Blarina brevicauda Baird, Mamm. N. Am. p. 42 (part).

r $85^{8}$ Blarina talpoides Baird, Mamm. N. Am. p. 37 (part).

I884 Blarina brevicauda Merriam, Linn. soc. New York. Trans. I884. $2: 66$.

1896 Blarina brevicauda Fisher, The Observer. May 1896. 7 : 194. I 898 Blarina brevicauda Mearns, Am. mus. nat. hist. Bul. 9 Sep. I898. $10: 373$.

x898 Blarina brevicauda Mearns, U. S. Nat. mus. Proc. $2 \mathrm{I}: 35^{6}$.

Type locality. Near Blair, Nebraska.

Fannal position. Boreal transition and upper austral zones.

Habitat. Fields and woods, wet or dry marshes, borders of streams. Every variety of country appears to be equally attractive to this animal.

Distribution in New Vork. The short-tailed shrew is one of the most abundant and widely distributed of the mammals that occur in the state. There are probably very few square miles in New York not inhabited by hundreds of individuals.

Principal records. De Kay: "This shrew is found in Albany county and in the southern parts of the state" ('42, p. I 8$)$... "I have had an opportunity of examining a recent specimen from Queens co. which I refer to this species" ('42, p r9). "[This shrew is] commonly found in this state" ('42, p, 2I). Merriam: "The short-tailed shrew is, I presume, the most abundant of the insectivorous mammals that occur in the Adirondack mountains, and is found alike in the dense coniferous forests of the interior and the cleared and settled districts of the surrounding region" (' $84 \mathrm{~d}, \mathrm{p} .66)$. Fisher: "A common species [in the neighborhood of Sing Sing]. Almost everywhere in the woods its tunnels may be found running hither and thither under the matting of dry leaves or old decayed logs. In the open meadows it is less common though occasionally found, attracted there no doubt by the meadow mice or other favorite food" ('96, p. 194). Mearns: "Very abundant from Schoharie creek up to the higher mountain tops where it appears to be less numerous though several were taken on the summit of Hunter mountain" (' $98 \mathrm{~b}$, p. $\left.35^{6}\right)$.

I have found the short-tailed shrew abundant at Geneva, Ontario co. Peterboro, Madison co. and Elizabethtown, Essex co.

Mr Savage writes that he has taken three or four specimens near Buffalo.

According to $\mathrm{Mr}$ Helme the short-tailed shrew is very common on Long Island. 
Remarks. The small Blarina parva a Say undoubtedly occurs in the lower Hudson valley though it has not to my knowledge been taken within the limits of the state.

De Kay included the animal on the ground of its occurrence in Connecticut ('42, p. 20). Mr Frank M. Chapman writes me that there is in the American museum of natural history a specimen of this shrew taken on the Hackensack marshes in New Jersey only a few miles from the New York state line. The species is to be looked for also in the upper austral area at the extreme western part of the state.

\section{Scalops aquaticus (Linnaeus) Naked-tailed mole}

I $75^{8}$ Sorex aquaticus Linnaeus, Syst. nat. ed. ro. $\quad$ I : 53 . I825 alquaticus F. Cuvier, Dents des Mamm. p. 25 I $\mathbf{1} 842$ Scalops aquaticus De Kay, Zoology of New. York, Mammalia p. I 5 (part).

I884 Scalops aquaticus Merriam, Linn. soc. New York. Trans., $2: 55$. 1896 Scalops aquaticus Fisher, The Observer. May 1896. $7:$ I94. r898 Scalops aquatious. Mearns, Am. mus. nat. hist. Bul. 9 Sep. r898. Io : 343 .

\section{Type locality. Eastern United States.}

Faunal position. Transition zone and austral zones.

Habitat. Dry, sandy soil.

Distribution in New York. The naked-tailed mole may be looked for in New York in suitable localities anywhere outside of the limits of the boreal zone. The details of its distribution in the state are unknown.

Principal records. De Kay: "The shrew-mole has a wide geographic range, being found from Carolina to the 5 oth degree of north latitude, and from the Atlantic to the shores of the Pacific" ('42, p. I7). Merriam: "This species is not common about the borders of the Adirondacks and is seldom if ever found within the evergreen forests, though it sometimes finds its way to the frontier settler's garden " ('84d, p. 55). Fisher: "Common, in the meadows and lawns [about Sing Sing]" ('96, p. 194).

Mr Helme writes that the naked-tailed mole is common on Long Island.

a 1823 Sorex parvus Say, Long's exped, to the Rocky mts. $1: 161$.

1842 Sorex parvus De Kay, Zoology of New York, Mamímalia. p. 19.

1895 Blarina parva Merriam, North Ameriean fauna, no. 10. 31 Dec. 1895 . p. 17.

Type locality. Near Blair, Nebraska.

Faunal position. Upper and lower austral zones.

Distribution. Upper and lower austral zones from the AIississlppl valley to the Atlantic coast. 


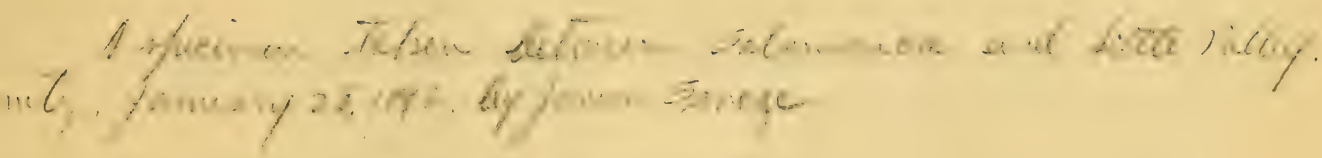



Remarks. De Kay's account of Scalops aquaticus clearly refers in part to the hairy-tailed mole since he records one specimen with 44 teeth.

\section{Parascalops breweri (Bachman) Hairy-tailed mole}

I842 Scalops aquaticus De Kay, Zoology of New York, Mammalia. p. I $_{5}$ (part).

I 844 Scalops breweri Bachman, Buston journ. nat. hist. $4: 32$.

I855 Scalops breweri Baird, N. Y. State cab. nat. hist. I5th rep. Append. A. p. I.

1884 Scapanus americanus Merriam, Linn. soc. New York. Trans. $2: 63$.

1895 Parascalops breweri True, Science, N. S. 25 Jan. r895. I : Ior. 1898 Parascalops breweri Mearns, Am. mus. nat. hist. Bul. 9 Sep. I 898. 10:343.

I 898 Parascalops breweri Mearns, U. S. Nat. mus. Proc. 21 : 357 .

Type locality. The type specimen of Scalops breweri was supposed to have been taken on the island of Marthas vineyard, Massachusetts (see Bachman, '44) but this is doubtless an error.

Faunal position. Boreal zone and perhaps northern part of transition zone.

Distribution in New York. The range of the hairy-tailed mole in New York is not well understood at present. The animal is probably common in open country throughout the northern half of the state. It also occurs in the Catskills and in the Hudson highlands. In his Revision of the American moles Mr F. W. True says: "All the New York specimens examined were from Lewis and Oneida counties, in the northwestern part of the state, but Bachman had 4 specimens from Troy, Rensselaer. co. [Audubon and Bachman '5r, p. 175]. No specimens have been taken in any part of southern or southeastern New York so far as I am aware" ('96, p. 73)

Principal records. De Kay: (A specimen of Scalops aquaticus with 44 teeth is mentioned ('42, p. $15-16)$, but no locality stated). Baird: "This species of mole, although not mentioned by De Kay in the State natural history, is in reality very abundantly to be met with in the northern part of the state and apparently to the exclusion of the more southern species with white naked tail, S. aquaticus ('65, p. I). Merriam: "I have secured a number of examples of this species from the borders of the wilderness, but have not observed it within the coniferous forests" ('84d, p. 63). Mearns: "This mole is probably rare in the [Hudson] highlands though common in the Catskill mountains. I have examined 
only two specimens. The first was picked up under a haypole on a saltmarsh beside the Hudson and identified by Dr C. Hart Merriam. On June 28, 1878, Mr.William Church Osborn brought me a perfect albino specimen of this mole which a gardener had caught near Garrison's in Putnam co." (' $98 \mathrm{a}$, p. 343-44). "One specimen taken [in the Schoharie valley]" ('98b, p. 357 ).

I have found the hairy-tailed mole tolerably common at Peterboro, Madison co. and Elizabethtown, Essex co.

Mr Savage has not found the animal at Buffalo, but I have seen a specimen belonging to Ward's natural science establishment taken near Rochester.

\section{Condylura cristata (Linnaeus) Star-nosed mole}

I $75^{8}$ [Sorex] cristatus Linnaeus, Syst. nat. ed. Iо. I : 53 .

1819 Condylura cristata Desmarest, Jour. de Physique. 89 : 23 o.

I 842 Condylura cristata De Kay, Zoology of New York, Mammalia. p. I4.

I884 Condylura cristata Merriam, Linn. soc. New York. Trans. $2: 48$. I896 Condylura cristata Fisher, The Observer. May 1896. 7: 195. I 898 Condylura cristata Mearns, Am. mus. nat. hist. Bul. Io: 344 .

Type locality. Pennsylvania.

Faunal position. The star-nosed mole is a member of the boreal fauna, but it ranges far south of the limits of the boreal zone in cool, damp situations.

Habitat. Swamps and soft damp ground. The tunnels inhabited by the star-nosed mole are often found partly filled with water. In its semi-aquatic habits this species differs strikingly from the two other moles found in New York.

Distribution in New York. This species is the most widely distrib uted of the moles that occur in the state It is probably an inhabitant of every county. The exact details of its range however remain to be determined.

Principal records. De Kay: "The star-nose is abun'dant throughout New York." ('42. p. I4). Merriam: "The star-nosed mole is a common animal along the outskirts of the Adirondacks, where it seems to manifest a predilection for moist situations" ... ('84d, p. 48). Fisher: "The star-nosed mole is far less common than the preceding species [Scalops aquaticus], and usually inhabits wet meadows near streams though occasionally taken in dry soil" ('96, p. 195). Mearns: "This singularlooking animal is not uncommon [in the Hudson highlands]" ('98a, p. 344). 


I have found the star-nosed mole common at Geneva, Ontario co.; Peterboro, Madison co, and Elizabethtown, Essex co.

Mr Savage writes that this species is not rare in the neighborhood of Buffalo, though less numerous than the naked.tailed mole.

"Several years ago I found a specimen lying dead in the street at Miller place, Long Island. This is my only record for the region" (Helme).

\section{Myotis lucifugus (Le Conte) Little brown bat}

183r Vespertilio lucifugis Le Conte, McMurtrie's Cuvier, Animal kingdom. Append. I: 43I.

i 842 Vespertilio subulatus De Kay, Zoology of New York, Mammalia. p. 8 (part).

r864 Vespertilio lucifugus $\mathrm{H}$. Allen, Monogr. bats N. Am. p. 55 . 1884 Vespertilio subulatus Merriam, Linn soc. New York. Trans. 2: 96 (part).

1893 Vespertilio gryphus Var. (a) Vespertilio gryphus lucifugus, $\mathrm{H}$. Allen, Monogr. bats N. Am. p. 78 .

1896 Vespertilio lucifugus Fisher, The Observer. 7: 195.

I897 Myotis lucifugus Miller, North American fauna. no. 13. p. 59. I 898 Myotis lucifugus Mearns, U. S. Nat. mus. Proc. 2 r : 357 .

Type locality. Southern Georgia.

Faunal position. The little brown bat ranges from Florida to Alaska, or throughout the breadth of five life zones. Such a distribution is very difficult to understand in the absence of definite knowledge of the real climatic conditions to which the animal is exposed during its breeding season.

Habitat. Caves, hollow trees and crevices in buildings. Dr Harrison Allen refers to this bat as "a strictly pastoral species" which " is not collected in houses either in town or country" ('93, p. 84). This statement is very misleading as the little brown bat often takes up its abode in buildings where it occasionally becomes a serious pest. This is the common bat of the Mammoth cave (Rhodes, ' $97 \mathrm{~b}, \mathrm{p} .59$ ).

Distribution in New York. As might be expected from its wide range, the little brown bat occurs throughout New York state. It is not equally common in all localities however, and the details of its local distribution remain to be worked out.

Principal records. De Kay: (Mentioned as a common species. The account probably refers partly to this animal and partly to $M$. subulatus. '42, p. 9). Merriam: "Next to the silver-haired bat this is the commonest and most universally distributed species in the Adirondacks, so 
far as my observations have extended. Professor Baird has taken the typical animal at Elizabethtown, and the form known as lucifugus at Westport" ('84, p. 96). Fisher: "Out of the hundreds of bats collected only one of this species was ever secured". ('96, p. 195). Miller: "The species is recorded from Adirondacks, Big moose lake, Catskill mountains, Howe's cave, Lake George, Locust grove, Lyons falls, Oneida lake, Peterboro, Sing Sing and.West point" ('97, p. 62). Mearns: "This was the commonest bat in the Catskills and seen nightly" (' $98 \mathrm{~b}$, p. 357).

I have found the little brown bat excessively abundant near the southeast shore of Oneida lake. Here it occurred in large colonies between rafters in barns and under the roofs and loose clapboards of old houses. At Peterboro the animal though less numerous than at Oneida lake, is common.

Mr Savage has taken a small brown bat, in a cave in the Niagara river gorge near the Devil's hole, which with some doubt he refers to this species.

\section{Myotis subulatus (Say) Say's bat}

I 823 ? Vespertilio subulatus Say, Long's exped. to the Rocky mts $2: 65$ footnote.

1842 Vespertilio subulatus De Kay, Zoology of New York, Mammalia. p. 8 (part).

I864 Vespertilio subulatus H. Allen, Monogr. bats N. Am. p. 5 I. I884 Vespertilio subulatis Merriam, Linn. soc, New York. Trans. $2: 9^{6}$ (part).

I 893 Northern form of Vespertilio gryphus H. Allen, Monogr. bats N. Am. p. 80.

I897 Myotis subulatus Miller, North American fauna. no. I3. p. 75 . ז 898 Myotis subulatus Mearns, Am. mus. nat. hist. Bul. 9. Sep. 1898. ro: 344 .

Type locality. Arkansas river, near La Junta, Colorado.

Faunal position. Too little is known of the range of this bat to permit the species to be assigned any definite faunal position. At present it is known to occur in the boreal, transition and upper austral zones.

Habitat. Probably similar to the little brown bat.

Distribution in Nere York. Say's bat probably occurs throughout the state but the details of its distribution are unknown.

Principal records. De Kay : (The account given by De Kay doubtless refers in part to this species) H. Allen: Specimen recorded from Elizabethtown, Essex co. ('64, p. 53). This is the first definite New 

York record. Merriam: Reference made to the Elizabethtown specimen previously recorded by Harrison Allen ('84, p. 96). Miller : Specimens mentioned from Hammondville, Hemlock lake, Highland falls, Lake George and Peterboro ('97c, p. 76). Mearns: "This bat is quite uncommon in the Hudson highlands" ('98a, p. 344).

I have taken a few specimens of Say's bat at Peterboro, Madison co. where it is much less common than the little brown bat.

\section{Lasionycteris noctivagans (Le Conte) Silvery bat}

183I Vespertilio noctivagans Le Conte, McMurtrie's Cuvier, Animal kingdom. June I83I. I : 3 I.

r8 $8_{3}$ Vespertilio auduboni Harlan, Monthly Amer. journ. geol. and nat. hist. Nov. I83 I. I : 220.

1842 Vespertilio noctivagans De Kay, Zoology of New York, Mammalia. p. 9 .

I864 Scotophilus noctivagans H. Allen, Monogr. bats N. Am. p. 39 . 1865 Lersy tericnactizagans-Peters, Monatsber. K. Preuss. Akad. Wissensch. Berlin. p. 648 .

I884 Vesperugo noctivagans Merriam, Linn. soc. New York. Trans. $2: 90$.

1893 Lasionycteris noctivagans $\mathrm{H}$. Allen, Monogr. bats N. Am. p. I05. 1896 Vespenugo noctivagans Fisher, The Observer. May i 896. 7: 95 . r897 Lasionycteris noctivagans Miller, North American fauna. no. I3. I6 Oct. 1897 . p. 86.

I898 Lasionycteris noctivagans Mearns, Am. mus. nat. hist. Bul. 9 Sep. 1898 . $10: 345$.

Type locality. Eastern United States.

Fannal position. Boreal transition and northern edge of upper austral zones.

Distribution in New York. The silvery bat is found either as a migrant or summer resident throughour the state. While its breeding range scarcely reaches the upper limit of the upper austral zone, its migrations carry it to the Bermudas and to the extreme southern United States (see Merriam, '88, p. 85 and Miller, '97a, p. 543).

Principal records. De Kay: "The silver-haired bat is common on Long Island and the southern counties of the state" ('42, p. Iо). Merriam: "This is our commonest bat, far outnumbering all the other species together. I have killed it in various parts of the wilderness, and during the past summer ... shot over 125 in Lewis co. ..." ('84d, p. 9०). Fisher: "Tolerably common [near Sing Sing] ... On June 24, 
I884, Mr Howard Acker found 16 females with 25 young from one to three days old under the siding of an old house " ('96, p. 196). Mearns: "One specimen was taken from a hollow tree [at Highland falls]" ('98a, p. 345).

Mr Helme writes that the silvery bat is very common on Long Island.

Pipistrellus subflavus subflavus (F. Cuvier) Georgia bat I834 Vespertilio georgianus F. Cuvier, Nouv. ann. d'hist. nat. Paris $2: 16$ (not determinable).

r834 Vespertilio subflavus F. Cuvier, Nouv. ann. d'hist. nat. Paris. I : $\mathbf{7}$.

I864 Scotophilus georgiamus H. Allen, Monogr. bats N. Am. p. 35 . I893 Vesperugo carolinensis H. Allen, Monogr. bats N. Am. p. I 2 I. 1896 Vesperugo georgianus Fisher, The Observer, May I896. 7:196. 1897 Pipistrellus subflavus Miller, North American fauna. no. 13: p. 90. r.898 Pipistrellus subflavus Mearns, Am. mus. nat. hist. Bul. Io:345.

Type locality. Eastern United States; probably Georgia.

Faunal position. Austral zones and lower edge of transition zone.

Distribution in New York. The Georgia bat is abundant in the lower Hudson valley but is not as yet known in other parts of the state.

Principal records. Fisher: "The commonest bat [at Sing Sing]. On warm summer evenings . . . hundreds may be seen flying back and forth over fields or lakes busily engaged in collecting their diminutive prey" ('96, p. I96). Mearns: "This bat is not abundant in the [Hudson] highlands" ('98a, p. 345).

I have taken one specimen of Pipistrellus at Peterboro, Madison co., but as it is immature I am unable to refer it satisfactorily either to the typical form or to $P$. subflavus obscurus.

\section{Pipistrellus subflavus obscurus Miller Dusky bat}

I 897 Pipistrellus subflavus obscurer Miller, North American fauna. no. I3. 16 Oct. 1897 . p. 93 .

Type locality. Lake George, Warren co. New York.

Faunal position. Probably the border line between transition zone and upper austral zone.

Distribution in Nere York. This bat has been found at the type locality only.

Principal records. Miller: 34 specimens recorded ('97c, p. 93). 




\section{Vespertilio fuscus Beauvois Brown bat}

r796 Vespertilio fuscus Beauvois, Cat. Peale's museum. p. I4. r842 Vespertilio carolinensis De Kay, Zoology of New York, Mammalia. p. Iо.

I 864 Scotophilus fuscus H. Allen, Monogr. bats N. Am, p. 3 I.

I884 Vesperugo serotinus fuscus Merriam, Linn. soc. New York. Trans. $2: 86$.

I893 Adelonycteris fuscuis H. Allen, Monogr. bats N. Am. p. II 2.

x896 Vesperugo fuscus Fisher, The Observer. May i 896. 7: 95 .

I897 Vespertilio fuscus Miller, North American fauna. no. г3. 16 Oct. 1897. p. 96.

1898 Vespertilio fuscus Mearns, Am. mus. nat. hist. Bul. 9 Sep. I 898 . Iо : 344 .

I893 Vespertibio fuscus Mearns, U. S. Nat. mus. Proc. 21 : 357.

Type locality. Philadelphia, Pa.

Faunal position. Austral zones and transition zone.

Habitat. Caves, hollow trees and crevices in buildings. This bat is usually very common in towns and cities.

Distribution in New York. 'The brown bat occurs throughout the nonboreal part of the state. The details of its distribution are not yet known.

Principal records. De Kay: "I have obtained it from Kings co. and Prof. Emmons has observed it at hilbany in the months of February and March" ('42, p. II). Merriam: "Professor Baird has taken this species at Westport in Essex co. on the eastern border of the Adirondacks and I have procured a single specimen in Lewis co. on the western side of the district, but it is unquestionably the rarest bat found within the limits of the region" (84d, p. 86) Fisher: "Common [at Sing Sing]" ('96, p. 195). Mearns: "The big brown bat is very common [at Highland falls], often entering houses in pursuit of insects" ('98a, p. 344). "Common [near Kaaterskill junction]" ('98b, p. 357).

I have never met with this bat in New York.

Mr Savage writes: "The brown bat has been taken here on one occasion at least. Some time ago one of the pupils of the Central high school took a live specimen to Dr F. W. Barrows who had it mounted. I have recently examined the specimen."

\section{Lasiurus cinereus (Beauvois) Hoary bat}

I796 Vespertilio linereus Beauvois, Cat. Peale's museum. p. I4 (obvious misprint for cinereus).

1842 Vespertilio pruinosus De Kay, Zoology of New York, Mammalia. p. 7 . 
I864 Lasiurus cinereus H. Allen, Monogr. bats N. Am. ' p. 2 I. 1884 Atalapha cinerea Merriam, Linn. soc. New York. Trans. 2: 78. I893 Atalapha cinerea H. Allen, Monogr. bats N. Am. p. I55. 1896 Atalapha cinerea Fisher, The Observer. May r896. 7: rg6. I897 Lasiurus cinereus Miller, North American fauna. no. I3. I6 Oct. I 897. p. I I 2 .

Type locality. Philadelphia, $\mathrm{Pa}$.

Faunal position. The breeding range of the hoary bat appears to be strictly confined to the boreal zone.

Habitat. Forests and woodlands except during migrations when the animal may be found anywhere.

Distribution in New York. So far as known this bat does not occur outside of the boreal area in the Adirondacks during the breeding season. Its migrations carry the animal far south of the boundaries of the state (Merriam, '88, p. 85; Miller, '97a, p. 542-43).

Principal records. De Kay: (The hoary bat regarded as uncommon ('42, p. 9). Merriam: "This species ... is not rare in the Adirondacks, and $I$ have taken it both in the interior and along the western border of the region" ( $84 \mathrm{~d}$, p. 78 .) Fisher: "On the evening of October 1,1883 one of these beautiful bats was seen flying about a lawn, [at Sing Sing] where it was well identified" (' $\left.96, p .19^{6}\right)$.

Of this species in the vicinity of Buffalo Mr Savage writes, "The hoary bat also occurs but in what numbers I am unable to say. There is a good specimen in the museum of the Buffalo society of natural sciences.

"Rare on Long Island. Has been taken in August, September and October" (Helme).

\section{Lasiurus borealis (Müller) Red bat}

I776 Vespertilio borealis Müller, Natursyst. Suppl. p. 20.

$\mathbf{1 8 4 2}$ Vespertilio noveboracensis De Kay, Zoology of New York, Mammalia. p. 6.

1864 Lasiurus noveboracensis H. Allen, Monogr. bats N. Am. p. $5^{\text {I. }}$ I884 Atalapha noveboracensis Merriam, Linn. soc. New York. 'Trans. $2: 83$.

I893 Atalapha noveboracensis H. Allen, Monogr. bats N. Am. p. I42. I896 Atalapha borealis Fisher, The Observer. May 1896. $7: 196$. I897 Lasiurus borealis Miller, North American fauna. no. 13. I6 Oct. I897. p. Io6.

r898 Lasiurus borealis Mearns, Am. mus. nat. hist. Bul. 9 Sep. 1898 . I0: 345 . 



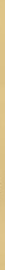


Type locality. New York state.

Fannal position. The red bat breeds throughout the austral zones, the transition zone and the lower part of the boreal zone.

Habitat. Forests, woodlands, groves and parks. The red bat appears to be an almost exclusively arboreal species.

Distribution in New York. The red bat probably occurs commonly throughout New York state, except, perhaps, in the central part of the Adirondack region. This species is extensively migratory (Merriam, '88 p. 85 ; Miller, '97a, p. 54I-42 ; Mearns, '98a, p. 345).

Principal records. De Kay: "This is the most common species in our state" ('42, p. 6). Merriam: "This species ranks among the least common bats of the area under consideration" ('84d, p. 83). Fisher: "Next to the little Georgian bat the red bat is the commonest species [in the neighborhood of Sing Sing]" ('96, p. 196). Mearns: "Very abundant in this region [the Hudson highlands] during the summer . . . During the latter part of October and the first week of November, I have seen great flights of them during the whole day" (' $98 \mathrm{a}, \mathrm{p}$. 345).

I have found the red bat a common summer resident at Peterboro, Madison co.

Mr Savage writes that, of the bats that occur in the neighborhood of Buffalo, the red bat appears to be the most numerous.

Mr Helme reports that this species is the commonest bat on Long Island.

\section{Addenda}

The following papers should be mentioned which were overlooked in preparing the body of this paper:

De Kay, J. E: 'Assembly document r6r, 1837. New York geological and mineralogical reports for $1836, \mathrm{p} . \mathrm{r}_{3}-\mathrm{r} 5$. In this communication it is estimated that 60 different species of mammals occur in the state.

De Kay, J. E. Assembly document 50, I840. New York geological and mineralogical reports for 1839 , p. $7-36$. In this article 74 mammals are mentioned as occurring in the state. The list here given includes introduced and fossil forms, also a number of synonyms, several species that are mentioned without positive knowledge of their occurrence in this state and some few that prove to have been founded on insufficient characters, making the number of New York mammals then known less than 60 .

F.J.H.M. 


\section{Fossil species}

Platigonus compressus Le Conte Fossil peccary

I848 Platigonus compressus Le Conte, Am. jour. sci. and arts. ser. 2. $5: 103$.

1889 Platygonus compressus Leidy, Wagner free inst. of science of Philadelphia. Trans. Dec. I88.9. 2:47.

Type locality. "The lead region of Illinois" (Le Conte, '48, p. I02)

Distribution in New York. Bones of the fossil peccary have been found near Rochester, but at no other locality in the state to my knowledge.

Principal records. Leidy: "Recently the writer procured through purchase for the Academy of natural sciences of Philaclelphia . . . a col. lection of remarkably well-preserved remains of two adult individuals of Platygonus compressus which were found in making a railway excavation in a gravel bank a few miles from Rochester. Of one individual there is the greater part of the skeleton, consisting of the nearly perfect skull with the teeth . . 2 I vertebrae, the sacrum, the long bones of both pairs of limbs, the imperfect scapulae, an innominatum, and part of a second, both pairs of principal metacarpals, one pair of principal metatarsals, an astragalus, a calcaneum, portions of a stcrnum and fragments of three ribs. Of the second individual there is a less perfect skull with the upper teeth but without the mandible" ('89, 4I).

\section{Equus major De Kay Fossil ho se}

1842 Equns major De Kay, Zoology of New York, Mammalia. p ro8. r884 Equus major Merriam, Linn. soc. New York. Trans. Aug. I884. $2: 47$.

Type locality. Navesink hills, New Jersey.

Distribution in New York. Remains of the fossil horse have been found at Keene's station, near the Oswegatchie river $\mathrm{Ox}$ Bow, in Jefferson co.

Principal records. De Kay: "Teeth and bones of the horse have been found in various parts of the Union, but I am unacquainted with any locality in this state. The nearest approach to it are the teeth and vertebrae found near the Navesink hills in New Jersey. . . They have also been found on the north branch of the Susquehannah; in digging the Chesapeake canal near Georgetown. D. C. and in North Carolina - I6 miles below Newbern" ('42, p. I08). Merriam: Dr C. C. Benton of Ogdensburg has shown me several fossil molar teeth of Equus major 


that were exhumed at Keene's station near the Oswegatchie Ox Bow in Jefferson co. I have compared them with the corresponding teeth in an immense dray-horse, and find them much larger" ('84, p.).

\section{Elephas columbi Falconer Fossil elephant}

I842 Elephas americanus De Kay, Zoology of New York, Mammalia. p. Ior. Not Elephas americamus Kerr, 1792.

I 857 Elephas columbi Falconer, Quart. journ. geol. soc. London. v. I3, table facing p. 319 .

Type locality. Mexico and the southern United States.

Distribution in New York. Remains of the fossil elephant may be looked for in marl beds, gravel banks and similar locations anywhere in New York. They are much less abundant however than those of the mastodon.

Principal records. De Kay: "The specimens ... were found in a diluvial formation near the Irondiquoit river in Monroe county ro miles east of the city of Rochester ... these consisted of a tusk and two molars" ('42, p. ro1).

\section{Mastodon americanus Kerr American mastodon}

I792 Elephas antericanus Kerr, Animal kingdom. I : I 6 .

I842 Mastodon maximus De Kay, Zoology of New York, Mammalia. p. 102.

I895 Mastodon americanus Allen, Am. mus. nat. hist. Bul. 20 June 1895. $7: 187$.

Type locality. Big bone lick, Kentucky.

Distribution in New York. Like the fossil elephant the mastodon once occurred throughout the state. Its remains are more abundant than those of the elephant.

Principal records. De Kay, "In this state the remains of this animal were discovered near Claverack, as early as I705, and formed the subject of a note from the celebrated Dr Mather, which appeared in the English philosophical transactions, I 705 , July 23.

"In 1782 , they [bones of the mastodon] were found in a swamp, near Montgomery, Orange co., and in greater numbers at Shawangunk, Ulster co. Shortly after, portions of eight distinct individuals were discovered within eight or to miles of Montgomery. In I80I, Mr Peale succeeded in disinterring, from this region, an almost entire skeleton.

"Since that period, other localities have been discovered, the most remarkable of these are, 
I From Rockland county, in I 8 I 7 ; and from Chester, Orange co....

2 In the same year, remains were found in the city of Rochester, 4 feet below the surface, in a hollow or water course.

3 In 1823, more than one half of a lower jaw, with the teeth, on the shore of Long-Island, between high and low water mark, about four miles east of the county court-house at Riverhead, Suffolk co. . . . It may be noted that a very large molar, in Dr Morton's collection, was fished up from a similar locality, namely, in the ocean at Long Branch, N. J. . .

4 At Geneseo, Livingston co. (see Am. jour. I $2: 3^{8}$ I) the greater part of a skeleton was found in a marsh $2 \mathrm{I} / 2$ feet below the surface, in vegetable mould, and resting upon a bed of fine white gravel.

5 In 1834 , the molar tooth of this species was found near Jamestown, Chautauqua co.

6 A fine portion of the lower jaw of a young mastodon, from the town of Montgomery, Orange co. . . .

7 In the town of Shawangunk, Ulster co.

8 At Perrinton, near Rochester, Monroe co.

9 At Coeymans, Albany co.

ro At Hinsdale, Cattaraugus co, a tusk was found i 7 feet beneath the surface. The soil was composed of alternate strata of sand and gravel.

I I In I84I, in a bed of marl three miles south of Le Roy, [a tooth ?] weighing two pounds.

I 2 A tooth was found in digging a mill-race on Goat Island, Niagara co., I 2 or 13 feet below the surface" ('42, p. I03-4).

The remains of numerous mastodons have been found in New York since $\mathrm{r} 842$, but it is hardly necessary to bring together a complete list.

Warren (' 52 ) records a nearly complete skeleton discovered near Newburgh in $\mathrm{x} 845$.

Hall ('7 I) records a skeleton, likewise essentially perfect, from Cohoes. He says: "In the month of September 1866 the workmen engaged in excavations for the foundation of a new mill to be erected by the "Harmony mills co. of Cohoes, N. Y." discovered the lower jaw of a mastodon with a single foot bone, resting upon a projection of rock between two depressions or concave walls of small put-holes in the margin of what afterward proved to be, a larger pot-hole" ('7 I, p. 99). Further excavations brought to light the remainder of the skeleton, some parts of which lay 60 feet away from the spot where the jaw was found. This specimen is in the N. Y. state museum.

Clarke ('88) reports the discovery of bones of a mastodon or elephant (probably the former) in the village of Attica, Wyoming co. This specimen is specially interesting on account of its close association with human relics. 



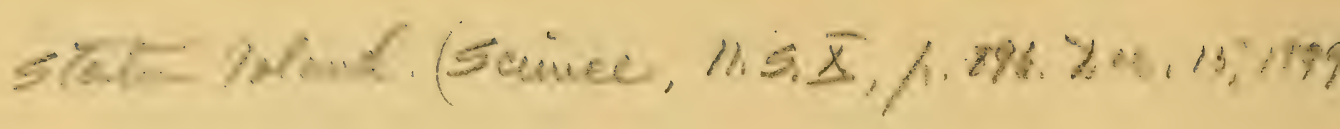


Marsh ('92) describes a skeleton in the museum of Yale university which is "perhaps in the best preservation of any skeleton of the American mastodon yet discovered." I am informed, however, that it lacks the hind legs. Dana ('95, p. 999) states that this skeleton was found at Otisville, Orange co.

The Newburgh mastodon. "The mastodon discovered about two months ago at Newburgh, N. Y., has now been more fully uncovered, but thus far proves to be an incomplete skeleton. The parts preserved are the skull, much injured by removal, both upper tusks, the vertebrae beginning at the last cervical and extending to near the tip of the tail, I 8 ribs on each side out of 20 , a right scapula and a complete pelvis and portions of the toot bones. No traces of the limbs have been found thus far, although extensive excavations have been made. Fortunately, Mr Schaefer, the owner, has removed the bones with care and treated them skilfully. Many very interesting observations could be made by a careful study and exploration of this locality. During a visit by the present writer, the following observations were made, partly with the aid of Mr Schaefer. The deposition is in three levels, the two upper being separated by a smooth clearly defined surface, and by slight differences in the character of the soil, which is largely dark and thoroughly decomposed vegetable matter, intermingled with few stones and very numerous remains of trees of various sizes. Examination of the latter gives abundant evidence of the existence of bearer in this hollow in the period of the mastodon, and we can easily imagine that the different soil levels were due to the building of successive beaver dams. When the dams were first completed the back flow of the water caused temporarily an interruption of the deposition of vegetation and may account for the differences of level above alluded to. The locality has been visited by a large number of people, including several well known paleontologists." -H. F. Osborn.

\section{Castoroides ohioensis Foster}

$183^{8}$ Castorondes ohioensis Foster, Second annual report on the geological survey of Ohio. $\mathbf{1}_{3} 8$. p. $8 \mathbf{I}$.

I 847 Castoroides ohioensis Hall, Boston journ. nat. hist. $5: 3^{8} 5$.

Type locality. "About one-half of a mile west of Nashport [Ohio]" (Foster, '38, p. 80).

Distribution in New York. Remains of Castoroides ohioensis have been found only once in New York — in a swamp near Clyde, Wayne co.

Principal records. Hall: "The cranium was received from Rev. Benjamin Hall, D.D., president of Geneva college, and was discovered 
in a swamp on the farm of Gen. W. H. Adams of Clyde. The situation in which it was found is an elevated plateau or level tract of land, a portion only of which would be denominated a swamp, though the whole surface is covered with a peaty soil which supports a heavy growth of elm, hemlock and ash with some maple and beech ... The precise locality of the fossil was near the termination of a shallow ravine or the bed of a small stream which flows into Lake Ontario in a northwesterly direction " ('47, p. $\left.3^{8} 5^{-86}\right)$.

\section{BIBLIOGRAPHY}

The following bibliography consists of the titles of the works referred to in the present paper, with the exception of those mentioned in the tables of synonymy only, where full references are always given.

Allen, Harrison. '64. Monograph of the bats of North America. (see Smithsonian miscellaneous collections. no. I65. June 1864)

'93. Monograph of the bats of North America. (see United States national museum. Bulletin 43. I893)

Allen, J. A. '76. American bisons, living and extinct. (see Geological survey of Kentucky. I876, v. I, pt 2, p. I-9, 1-246)

_ '77. Monographs of North American rodentia. (see United States geological survey of the territories 9 th report. Aug. 1877)

_ '8o. History of North American pinnipeds, a monograph of the walruses, sea-lions, sea-bears and seals of North America. (see United States geological and geographical survey of the territories. Miscellaneous publications. no. I2. I880)

_ '94a. Notes on the mammals of New Brunswick, with description of a new species of Evotomys. (see American museum natural history. Bulletin 6. p. 99-106)

'94b. Remarks on a second collection of mammals from New Brunswick, and on the rediscovery of the genus Neotoma in New York state. (see American museum natural history. Bulletin. 22 Dec, r894. $6: 359-64)$

American ornithologists' union. '89. Check-list of North American birds. Abridged ed. revised. I889.

Audubon, J. J. \& Bachman, J. '4r. Description of new species of quadrupeds inhabiting North America. (see Academy natural sciences, Philadelphia. Proceedings. Oct. 184I. I:92-103) 


Audubon, J. J. \& Bachman, J. '42. Descriptions of new species of quadrupeds inhabiting North America. (see Academy natural sciences, Philadelphia. Journal. ser. I, v. 8, pt 2, p. 92-103. Reprint of '4r)

—_ '46, '51, '54. The viviparous quadrupeds of North America v. I, 1846 , v. 2,185 r, v. 3,1854 .

Bachman, J. '37a. Observations on the different species of hares (genus Lepus) inhabiting the United States and Canada. (see Academy natural sciences, Philadelphia. Journal. 1837. v. 7, pt 2, p $282-361$ )

- '37b. Remarks on the genus Sorex with a monograph of the North American species. (see Academy natural sciences, Philadelphia. Journal. I837. v. 7 , pt 2, p. 362-402)

__ ' 37 c. Additional note on the genus Lepus. (see Academy natural sciences, Philadelphia. Journal. 1837. v. 7, pt 2, p. 403)

_- '44. Observations on the genus Scalops' with descriptions of the species found in North America. (see Boston society natural history. Proceedings. 1844. I : 40-4I)

Bailey, Vernon. '96. Tamarack swamps as boreal islands. (see Science, new series 14 Feb. $1896 . \quad 3: 25^{\circ-5} \mathrm{I}$ )

- '97. Revision of the American voles of the genus Evotomys (see Biological society, Washington. Proceedings. I3 May 1897. 9: 1 I $3-38)$

_- '98a. Descriptions of II new species and subspecies of voles. (see Biological society, Washington. Proceedings. 30 Apr. r898. I $2: 85-9$ o)

'98b. New name for Microtus insularis Bailey. (see Science, new series. 2 Dec. $1898 . \quad 8: 782-83$ )

Baird, S. F. '57. Mammals [of North America] (see Explorations and surveys to ascertain the most practicable and economical route for a railroad from the Mississippi river to the Pacific ocean. Report 8. $\quad$ i 857 )

_ '65. Notice of a mole not enumerated by De Kay in the fauna of the state. (see $\mathrm{r}_{5}$ th report of the regents of the University of the State of New York, on the condition of the state cabinet of natural history, and the historical and antiquarian collection annexed thereto. I865. App. A, p. I) 
Bangs, Outram. '95. Geographical distribution of the eastern races of the cotton-tail (Lepus sylvaticus Bach.) with a description of a new subspecies, and notes on the distribution of the northern hare (Lepus americanus Erxl.) in the east. (Boston society natural history, Proceedings. 3I Jan. $1895 \quad$ 26:404-I4)

- '96a. Review of the weasels of eastern North America. (Biological society, Washington. Proceedings. 25 Feb. 1896 . Io: 1-24)

_ '96b. Notes on a small collection of mammals from Lake Edward, Quebec. (Biological society, Washington. Proceedings. 9 Mar. 1896. 10: $45^{-52)}$

_ ' 96 c. Notes on the synonymy of the North American mink, with description of a new subspecies. (Boston society natural history. Proceedings. Mar. $1896.7:$ I-6)

'96d. Skunks of the genus Mephitis of eastern North America. (Biological society, Washington. Proceedings. 28 Dec. 1896. I0: I39-44)

- '96e. Review of the squirrels of eastern North America. Biological society, Washington. Proceedings. 28 Dec. 1896. Iо : i45-67)

'98. Eastern races of the American varying hare, with description of a new subspecies from Nova Scotia. (see Biological society, Washington. Proceedings. 24 Mar. 1898. I2: 77-82)

Batchelder, C. F. '96a. Some facts in regard to the distribution of certain mammals in New England and northern New York. (see Boston society natural history. Proceedings Oct. 1896. 28:185-93)

- '96b. An undescribed shrew of the genus Sorex. (see Biological society, Washington. Proceedings. 8 Dec. 1896. 10: $\mathrm{r}_{33-34)}$

Bragaw, D. F. '83. [Opossums at Woodside, Long Island]. (see Forest and stream. II Jan. I883. I9:467)

Britton, N. L. \& associates. '88. Preliminary catalogue of Anthophyta and Pteridophyta reported as growing spontaneouly within ıро miles of New York city. 25 Apr. I898.

Britton, N. L., \& Brown, A. ' 96 ,' '97 and '98. Illustrated flora of the northern United States, Canada and the British possessions from Newfoundland to the parallel of the southern boundary of Virginia and from the Atlantic ocean westward to the rozd meridian. v. I, I896. v. 2, I897. v. 3, I898. 


Clarke, J. M. '88. Report on bones of Mastodon or Elephas, found in association with human relics in village of Attica, Wyoming co., $\mathrm{N}$. Y. 1888 .

Colvin, Verplanck. '8o. Winter fauna of Mt Marcy. (see 7 th annual report on the progress of the topographical survey of the Adirondacks, to the year i879. Appendix. I880. 364-74)

Cope, E. D. ' 65 . Note on a species of whale occurring on the coasts of the United States. (see Academy natural sciences, Philadelphia. Proceedings. I865. I $7:$ I 68-69)

Coues, Elliott. '77. Monographs of North American rodentia. (see United States (ieological survey of the territories. Report. v. 9 Aug. I877)

Cuvier, F. '32. Essai de classification naturelle des vespertilions et description de plusieurs espèces de ce genre. (see Nouvelles annales du musée d'histoire naturelle (Paris). I : I-2 I)

Dana, Jas. D. '95. Manual of geology. Ed. 4. 998-999.

Day, D. F. '82-'83. Plants of Buffalo and its vicinity. (see Buffalo society of natural sciences. Bulletin no. 3. April 1882. 4:65-152; no. 4. $188 j \cdot 4: x 53-290)$

DeKay, J. E. '42. Natural history of New York. Zoology. pt r, Mammalia. I842.

Dutcher, B. H. ' '89. Bird notes from Little Gull island, Suffolk co., N. Y. (see Auk. April I889. 6:124-3I)

Emmons, Ebenezer. '40. Report on the quadrupeds of Massachusetts. (see Reports on the herbaceous plants and on the quadrupeds of Massachusetts. I840. I-86) (articles separately paged)

Falconer, H. '57. On the species of mastodon and elephant occurring in the fossil state in Great Britian. (see Geological society, London. quarterly jouınal. April 1857. 13:307-60)

Fischer, J. B. '29. Synopsis mammalium. 1829.

Fisher, A. K. '8I. Some of the bats of Westchester co. N. Y. (see Forest and stream. 2r July I88I. I6:490)

- '84. Seals in the Hudson off Sing Sing. (see Forest and stream. I० Apr. I884. $22: 203$ )

- '85a. Capture of an opossum in Essex co. N. Y. (see Forest and stream. 2 Apr. $1885 . \quad 24: 184$ ) 
Fisher, A. K. '85b. Capture of the pine mouse at Sing Sing, N. Y. (see American naturalist. Sep. I885. I9: 896)

___ '96. Mammals of Sing Sing, N. Y. (see The Observer May 1896. $7: 193-200)$

Foster, J. W. '37. Miscellaneous observations made during a tour in May, $x 835$, to the falls of the Cuyahoga, near Lake Erie: extracted from the diary of a naturalist. (see American journal science and arts. Jan. $1837.21: 1-84)$

- '38. Report. (see $2 \mathrm{~d}$ annual report on the geological survey of Ohio. 1838 . 73-107)

Fraser, A. A. '89. Opossums on Long Island. (see Forest and stream. 4 Apr. $\quad$ i889. $32: 212$ )

Gueldenstaedt, A. I. '76. Chaus, animal feli affine descriptum. (see Novi commentarii academiae scientiarum Imperialis Petropolitanae. (1775) $1776.20: 483-500$ )

Hall, James. '47. Notice of the geological position of the cranium of the Castoroides ohioensis. (see Boston journal of natural history. $5: 3^{8} 5-9$ I)

Hall, James. '7r. Notes and observations on the Cohoes mastodon. (see 2 Ist report of the regents of the University of the State of New York, on the condition of the state cabinet of natural history. App. F, 99-148)

Hill, Franklin C. '82. The opossum at Elmira, N. Y. (see American naturalist. May: 1882 . I6:403)

Hornaday, W. T. '89. Extermination of the American bison with a sketch of its discovery and life history. (see Annual report of the board of regents of the Smithsonian institution showing the operations, expenditures, and condition of the institution for the year ending June 30, 1887. 1889. pt 2, 373-548)

_ '98. Destruction of our birds and mammals. (see $2 \mathrm{~d}$ annual report of the New York zoological society. I5 Mar. 1898. 77-126)

Howard, L. O. '95. Further notes on the San José scale. (see Insect life. March 1895 . 7: 283-95)

Kerr, Robert. '92. The animal kingdom, or zoological system of the celebrated Carolus Linnaeus. v. I, I792. 


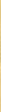

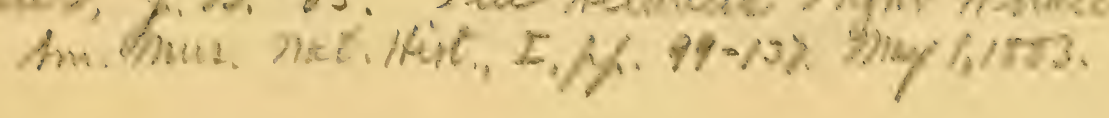



Le Conte. '48. Notice of five new species of fossil mammalia from Illinois. (see American journal science and arts, ser.2. 5:102-6)

Leidy, Joseph. '89. On Platygonus, an extinct genus allied to the peccaries. (see Wagner free institute of science of. Philadelphia. Transactions. Dec. I889. $2: 4 \mathrm{I}-5^{\circ}$ )

Lintner, J. A. '8o. Lepidoptera of the Adirondack region. (see 7 th annual report on the progress of the topographical survey of the Adirondack region of New York; to the year 1879. App. I880. $375-400)$

Loring, J. A. '99. Occurrence of the Virginia opossum in Southern Central New York. (see Science, new series. I3 Jan. 1899. 9:71)

[Lucas, F. W.] '82. [Porcupine and opossum near Rochester] (see Ward's natural science bulletin. no. 3. I Apr. 1882. 1:7)

Lydekker, R. '98. Deer of all lands; a history of the family Cervidae living and extinct. $\quad \mathbf{8} 889$.

Marsh, O. C. '92. Restoration of Mastodon americanus, Cuvier. (see American journal science and arts. ser. 3. Oct. I892. $44: 35^{\circ}$ )

Mearns, E. A. ' 98 a. Study of the vetebrate fauna of the Hudson highlands, with observations on the mollusca, crustacea, lepidoptera, and the flora of the region. (see American museum natural history. Bulletin 9 Sep. 1898 . 10:303-52)

—_ ' $98 \mathrm{~b}$. Notes on the mammals of the Catskill mountains, N. Y. with general remarks on the fauna and flora of the region. (see United States National museum. Proceedings. 4 Nov. 1898. 2 I : 34 I-60)

Merriam, C. Hart. '8га. Tree-climbing woodchucks. (see Forest and stream. 7 July i88 r. I6:453)

— '8I b. Beech nuts and woodpeckers. (see Forest and stream. I Dec. I 88 I. I $7: 347)$

- '82. Vertebrates of the Adirondack region, northern New York. (see Linnaean society, New York. Transactions. Oct. I882. I : 9-106)

'83. Chipmunks and red squirrels. (see Forest and stream. 6 Sep. 1883. $21: 103$ )

'84a. Seals in the upper St Lawrence. (see Forest and stream. I3 Mar. I884. 22 : 1 24) 
Merriam, C. Hart. ' 84 b. The muskrat as a fish-eater. (see Forest and stream. 27 Mar.1884. 22: 165 )

_ '84c. Another seal in Lake Ontario. (see Forest and stream. I 5 . May ז884. $22: 26_{3}$ )

_ 84 d. Vertebrates of the Adirondack region, northern New York. (see Linnaean society, New York. Transactions. Aug. r884. $\left.2: 9-2 I_{4}\right)$

' 84 e. The 'hood' of the hooded seal, Cystophora cristata. (see Science. 5 Dec. I884. $4: 5$ I 4-16)

- '85. The pine mouse in northern New York. (see American naturalist. Sep. 1885 . 19:895)

- '86. Description of a new subspecies of the common eastern chipmunk. see American naturalist. Feb. I886. 20:236-42)

_ '88. Do any Canadian bats migrate? Evidence in the affirmative. (see Royal society, Canada. Transactions. (1887) г 888. Sec. $5: 85$ )

- '90. General results of a biological survey of the San Francisco mountain region and desert of the Little Colorado, Arizona, with special reference to the distribution of species. (see North American fauna. no. 3. I I Sep. I 89o: 3-54)

- '94. Laws of temperature control of the geographic distribution of terrestrial animals and plants. (see National geographic magazine. Dec. 1894 . 6:229-38)

__ '95a. Geographic distribution of animals and plants in North America. (see Yearbook of the United States department of agriculture for 1894. . 1895, 203-14)

- '95b. Revision of the shrews of the American genera blarina and notiosorex. (see North American fauna. no. Io. 3 I Dec. 1895 . 5-34)

- '95c. Synopsis of the American shrews of the genus sorex. (see North American fauna no. Io. 3I Dec. 1895. 57-98)

- '96. Synopsis of the weasels of North America. (see North American fauna. no. Ix)

_ '98. Life zones and crop zones of the United States. (see United States department of agriculture, division of biological survey. Bulletin ıо. Sep. 1898) 




Miller, G. S., jr. '93a. A jumping mouse (Zapus insignis Miller) new to the United States. (see Biological society, Washington: Proceedings. 22 Apr. $1893 . \quad 8: 1-8$ )

'93. Description of a new white-footed mouse from the eastern United States. (see Biological society, Washington. Proceedings. 20 June, 1893. 8: 55-70)

_ ' 94 . On a collection of small mammals from the New Hampshire mountains. (see Boston society natural history. Proceedings. 24 Mar. 1894. 26: 1 77-97)

'95a. [Letter on the occurrence of the cottontail in central New York] (in Bangs '95) (see Boston society naturai history. Proceedings. 3r Jan. I 895 . 26:4ro)

__ ' 95 b. Long-tailed shrews of the eastern United States. (see North American fauna. no. Io. 3i Dec. I895. p. 35-56)

__ '97a. Migration of bats on Cape Cod, Massachusetts. (see Science, new series. 2 Apr. 1897. $5: 54 \mathrm{I}-43$ )

_ ' $97 \mathrm{~b}$. Notes on the mammals of Ontario. (see Boston society natural history. Proceedings. 30 Apr. 1897. 28: I-44)

- '97c. Revision of the North American bats of the family Vespertilionidae. (see North American fauna. no. 13. 16 Oct. 1897)

__ ' 98 . An instance of local temperature control of the distribution of mammals. (see Science, new series. ${ }_{5}$ Nov. I898. 8:6 $15-18$ )

Morehouse, F. A. '83. [Opossum at Weedsport, N. Y.]. (see Forest and stream. II Jan. I883. I9:467)

Muller, P. L. S. ' 76 . Des Ritters Carl von Linné vollstandigen Natursystems Supplements und Register-Band. 17.76.

Osborn, H. F. The Newburgh mastodon. (see Science 13 Oct. 1899. I0: 539)

Palmer, T. S. '97. Extermination of noxious animals by bounties. (see Yearbook of the United States department of agriculture, 1896. I $897 \cdot 55-68$ )

Peck, C. H. '8o. Plants of the summit of Mt Marcy. (see 7 th annual report on the progress of the topographical survey of the Adirondack region of New York, to the year I879. App. 1880. 402-1:2)

Pierce, James. '23. Memoir on the Catskill mountains with notices of their:topography, scenery, mineralogy, zoology, economical resources, etc. (see American journal of science and arts (Silliman). 6:86-97) 
Plumb, C. S. '98. Geographic distribution of cereals in North America. (see United States department of agriculture, division of biological survey. Bulletin ro)

Rafinesque, C. S. 'ri. Description of seven new genera of North American quadrupeds. (see American monthly magazine. Nov. I 8 I $7 . \quad 3: 44-6$ )

_-22. Annals of nature or annual synopsis of new genera and species of animals, plants, etc., discovered in North America.

Reed, J. H. '98. The terns of Great Gull Island, N. Y., during I897. (see Auk. Jan. $1898.15: 40-3$ )

Rhoads, S. N. '94. Contribution to the history of the Alleghany cave rat, Neotoma magister Baird. (see Academy natural sciences, Philadelphia. Proceedings. Oct. I $89^{\circ} 4.2$ I $3-2 \mathrm{I}$ )

- '95a. Notes on the mammals of Monroe and Pike counties, Penn. (see Academy natural sciences, Philadelphia. (1894). Proceedings. Jan. $1895 \cdot \quad 387-96)$

'95b. Distribution of the American bison in Penn. with remarks on a new fossil species. (see Academy natural sciences, Philadelphia Proceedings. June 1895. 224-48)

_ '97a. Contribution to the mammalogy of northern New Jersey. (see Academy natural sciences, Philadelphia. Proceedings. Feb. 1897. 23-33).

- '97b. Some notes on the mammals of Mammoth cave, Kentucky. (see Cincinnati society natural history. Journal. 24 Mar. I 897. I9: 53-6r)

— '97c. Contribution to the mammalogy of central Pennsylvania. (see Academy natural sciences, Philadelphia. Proceedings. May I897. 204-26)

'97d. Notes on a collection of small mammals from northeastern North Carolina. (see Academy natural sciences, Philadelphia. Proceedings. 303-12)

— '98a. Owls', mice and moles. Question in economic zoology. (see Forest and stream 20 Aug. x898. 51 : I43-44)

_ '98b. "Noxious" or "beneficial"? False premises in economic zoology. (see American naturalist. Aug. 1898 . 32:570-8I) ' 98 c. Contributions to a revision of the North American beavers, otters and fishers. (see American philosophical society, new series. Transactions, Oct. I898. v. I9, pt 2, p. 418-39) 

Scott, W. B. '85. Cervalces americanus, a fossil moose 'or elk, from the quaternary of New Jersey. (see Acardemy natural sciences, Philadelphia. Proceedings. I885. I8I-202)

Smith, A. M. '98. List of plants found on the Adirondack league club tract. (see Adirondack league club year book. I898. 59-7 I)

Smith, H. M. '94. Flora of Honnedagalake. (sce Adirondack league club hand-book for 1894 : I894. $\quad 4^{8-54}$ )

Stone, Witmer. '93a. Description of a new Evotomys from southern New Jersey. (see American naturalist. Jan. 1893. 27: 54-56)

- '93b. Description of a new species of Neotoma from Pennsylvania. (see Academy natural sciences, Philadelphia.' Proceedings. (I893) I6-I8)

Syracuse standard. '82. [Record of a seal shot in Onondaga lake in the suburbs of Syracuse] (see Syracuse standard. 29 Apr. I882. Forest and stream. II May i882. I8:286)

Temminck, C. J. ' '35-'4x. Sur les chiroptères vespertilionides formant les genres Nyctice, Vespertilion et Furie. (see Monographies de Mammalogie. I835-4I. 2:14I-272. [Treizieme Munographie])

Thompson, E. S. ' '98. List of the big game of North America. (see Forest and stream. 8 Oct. $1898 \quad 5^{1}: 285-86$ )

Thompson, Zadock. '42. Natural history of Vermont. (see History of Vermont, natural, civil and statistical. pt. I)

True, F. W. '89. Contribution to the natural history of the Cetaceans, a review of the family Delphinidae. (see National museum, new series. Bulletin. no. 36. r889)

-96. Revision of the American moles. (see National museum, new series. Proceedings. Dec. I896. I9: I-I I 2)

Warren, J. C. '52. The Mastodon giganteus of North America. Boston $185^{2}$.

Wyman, J. '46 [On Castoroides Ohioensis]. (see Boston society natural history. Proceedings. 2: $138-39$ )

47. Anatomical description of the same [cranium of Castoroides ohioensis]. (see Boston journal of natural history. 1847. 5:39I4 ㅇ) 





\section{N D E X}

The superior figures tell the exact place on the page in ninths; e. g. $3^{69}$ means page 369 , beginning in the third ninth of the page, i. e. about one third of the way down: Synonyms are printed in italics.

Adelonycteris fuscus, $369^{8}$

Alce americanus, $302^{8}$

Alces americanus, $302^{4}$

Arctomys monax, $308^{7}-9^{7}$

Arvicola' alborufescens, $274^{1}$

chrotorrhinus, $322^{8}-23^{3}$

dekayi, $3 \mathbf{I}^{1}-2 \mathbf{I}^{4}$

fulvus, $3 \mathrm{I}^{\circ}-2 \mathrm{I}^{4}$

gapperi, $3 \mathrm{I} 8^{8}-2 \mathrm{I}^{4}$

hirsutus, $273^{\circ} ; 323^{4}-24^{\circ}$

oneida, $274^{1}, 323^{4}-24^{8}$

pinetorum, $326^{2}-27^{1}$

riparius, $323^{4}-25^{9}$

rufescens, $318^{\circ}-2 \mathrm{I}^{4}$

scalopsoides, $326^{1}-27^{2}$

xanthognathus, $273^{7}, 323^{5}-24^{8}$

Atalapha borealis, $370^{\circ}-7 \mathrm{I}^{8}$

cincrea, $370^{1}$

noveboracensis, $370^{8}-7 \mathrm{I}^{\circ}$

Austral zone, $282^{1}, 289^{6}-92^{4}$

Balaena cisarctica, $297^{5}$ mysticetus, $2297^{5}$ rostrata, $296^{8}-97^{2}$.

Bat, brown, $369^{1}$ dusky, $275^{7}, 368^{8}$

Georgia, $275^{8}, 368^{2}$

hairy, $369^{\circ}-70^{\circ}$

little brown, $274^{4}, 365^{2}-66^{4}$

red, $370^{7}-71^{\circ}$

Say's, $274^{3}, 366^{4}-67^{2}$

silvery, $367^{3}-68^{2}$

Bear, black, $347^{1}$

Beaver, American, $3 \mathrm{II}^{8}-\mathrm{I} 2^{9}$

Bibliography, $376^{3}-85^{9}$ explanation, $293^{1}$

Birds of Canadian zone, $283^{\circ}$ of transition zone, $286^{1}$ of upper austral zone, $290^{1}$

Bison americanus, $297^{\circ}-99^{8}$ bison, $297^{8}-99^{8}$

Blackfish, $296^{2}$
Blarina brevicauda, $273^{8}, 360^{7}-62^{3}$ carolinensis, $273^{7}$

parva, $273^{7}$

talpoides, $36 \mathrm{I}^{1}$

Bos bison, $297^{8}-99^{8}$

Canadian zone, $281^{9}, 283^{3}$

Canis cinereoargenteus, $34 \mathrm{I}^{\mathrm{B}}-42^{4}$

fulvus, $342^{5}-43^{1}$

lupus, $343^{2}-46^{\circ}$ occidentalis, $343^{2}-46^{9}$ mibilis, $343^{8}-46^{\circ}$ occidentalis, $343^{2}-46^{\circ}$ vulpes $\Delta$ pennsylvanicus, $34 \mathrm{I}^{6}-42^{4}$

Cariacus americanus, $299^{9}-300^{8}$ virginianus, $299^{\circ}-300^{8}$

Caribou, $273^{8}$

Castor canadensis, $3 \mathrm{II}^{8}-\mathrm{I} 2^{9}$ fiber, $3 \mathrm{II}^{\mathrm{B}}-\mathrm{I} 2^{\circ}$ canadensis, $3 \mathrm{II}^{7}-\mathrm{I} 2^{9}$ zibethicus, $327^{2}-28^{2}$

Castoroides ohioensis. $375^{7}-76^{\prime \prime}$

Cervus alces, $302^{4}$ canadensis, $300^{\circ}-2^{8}$

dama americanus, $299^{8}-300^{\circ}$ elaphus caniadensis, $300^{3}-2^{3}$ virginianus, $299^{\circ}-300^{8}$

Chipmunk, northeastern, $274^{8}, 307^{8}-8^{6}$ southeastern, $307^{1}$

Condylura cristata, $364^{3}-65^{2}$

Cottontail, eastern prairie, $275^{4}, 334^{7}-$ $35^{8}$ northeastern, $275^{4}, 333^{6}-34^{6}$ southeastern, $332^{5}-33^{4}$

Cricetus myoides, $315^{3}-16^{5}$

Cystophora cristata, $35^{8}-57^{8}$

Deer, Virginia, $299^{8}-300^{8}$

De Kay, J. E. works on New York mammals, $273^{7}, 37 \mathrm{I}^{6}$

Delphinus delphis, $273^{8}, 275^{2}, 295^{4}$ melas, $296^{8}$ 
orca, $296^{\circ}$

phocaena, $295^{7}-96^{2}$

tursio, $295^{2}$

Didelphis virginiana, $273^{7}, 293^{3}-95^{1}$

Dipus hudsonius, $329^{5}-30^{8}$

Dorcelaphus virginianus, $299^{9}-300^{8}$

Elaphus americanus, $3 \mathrm{OI}^{1}-2^{3}$ canadensis, $300^{\circ}-2^{8}$

Elephant, fossil, $373^{3}$

Elephas americamis, $373^{2}, 373^{5}-75^{7}$ columbi, $373^{2}$

Equus major, $372^{7}-73^{1}$

Erethizon dorsatus, $331^{5}-32^{5}$

Evotomys gapperi, $274^{2}, 3 \mathrm{I}^{1}+2 \mathrm{I}^{4}$ gapperi, $318^{8}-2 I^{4}$ rhoadsi, $275^{7}, .321^{4}-22^{8}$

Evotomys rutilis gapperi, $319^{1}-2 \mathrm{I}^{4}$

Felis concolor, $336^{5}-39^{8}$ hippolestes, $336^{5}-39^{8}$

Lynx canadensis, $339^{9}-40^{6}$ oregonensis hippolestes, $336^{4}-39^{8}$ ruff $a, 340^{6}-4 \mathrm{I}^{5}$

Fiber zibethicus, $327^{2}-28^{2}$

Fisher, $354^{3}$

Flying squirrel, Canadian, $274^{8}$, $310^{8}-$ II $^{5}$ southern, $309^{8}-10^{7}$

Fossil species, $372^{1}-75^{7}$

Fox, gray, $34 \mathrm{I}^{6}-42^{4}$ red, $342^{4}-43^{1}$

Fox squirrel, northeastern, $306^{4}$

Globicephalus melas, $296^{2}$

Gray fox, $34 \mathrm{I}^{6}-42^{4}$

Gray squirrel, northern, $273^{9}, 304^{7}-6^{3}$

Gulo luscus, $350^{1}$

Harbor seal, $355^{8}-56^{8}$

Hare, southern varying, $335^{3}-36^{4}$

Hesperomys leucopus, $315^{3}-17^{6}$ myoides, $316^{6}-17^{6}$

Horse, fossil, $372^{6}-73^{1}$

Hudsonian zone, $281^{8}, 282^{4}$

Hyperoodon rostratus, $296^{8}-97^{2}$

Hystrix dorsatus, $33 \mathrm{I}^{5}-32^{5}$ hudsonius, $331^{6}-32^{5}$

Jumping mouse, $275^{3}, 329^{5}-30^{8}$ woodland, $330^{\circ}-3 \mathrm{I}^{\mathrm{s}}$

Killer, $296^{\circ}$

Lasionycteris noctivagans, $367^{3}-68^{2}$

Lasiurus borealis, $370^{7}-71^{6}$ cinereus, $369^{9}-70^{6}$ noveboracensis, $370^{8}-71^{6}$

Lemming, bog, $275^{5}, 328^{2}$ northern bog, $275^{8}, 329^{1}$
Lepus americamus (cottontail) $333^{5}-34^{n}$

americamus (hare) $335^{4}-36^{4}$

virginianus, $335^{3}-36^{4}$

var. virginianus, $335^{4}-36^{4}$

floridanus mallurus, $332^{5}-33^{4}$

mearnsi, $275^{4}, 334^{4}-35^{3}$

transitionalis, $275^{4}, 333^{5}-34^{6}$

nanus, $332^{5}-33^{4}, 333^{6}-34^{6}$

nuttalli mallurus, $332^{8}-33^{4}$

mearnsi, $334^{8}-35^{3}$

transitionalis, $333^{7}-34^{8}$

sylvaticus, $332^{5}-33^{4}, 333^{5}-34^{6}$

mearnsi, $334^{7}-35^{8}$

transitionalis, $333^{8}-34^{8}$

virginianus, $335^{4}-36^{ \pm}$

Life zones, $280^{4}-92^{4}$

Lutra canadensis, $347^{7}-48^{8}$

canadensis, $347^{8}-48^{8}$

hudsonica, $347^{7}-48^{6}$

Lutreola vison, $35 \mathrm{I}^{1}$

Lyncus borealis, $340^{1}$ rufus, $340^{7}-4 \mathrm{I}^{5}$

Lynx canadensis, $339^{8}-40^{6}$ montanus, $339^{\circ}-40^{6}$

ruffus, $340^{6}-4 \mathrm{I}^{\mathrm{s}}$

IMammals, added to list $I 842-82,274^{2}$ added in last Io years, $275^{1}$

history of list, $273^{6}-75^{8}$

names based on N. Y. specimens, $279^{1}-80^{8}$

species added by Merriam, $274^{\top}$

table 'showing growth of list, $275^{9}-78$

total number, $275^{1}$

total number in $1842,274^{2}$

Marten, $353^{\top}-54^{2}$

Mastodon, Newburgh, $375^{2}$

Mastodon americanus, $373^{5}-75^{7}$ maximus, $373^{5}-75^{7}$

Meadow jumping mouse, $329^{5}-30^{8}$

Meadow mouse, $274^{1}, 323^{3}-24^{6}$ yellow-cheeked, $273^{8}$

Mephitis americana, $348^{7}-49^{\circ}$ mephitica, $348^{6}-49^{9}$

Meriones americanus, $329^{6}-30^{8}$

Merriam, C. Hart, works on N. Y. mammals, $274^{6}$

Microtus chrotorrhinus, $275^{5}, 322^{3}-23^{3}$ insularis, $324^{7}-25^{9}$

nesophilus, $275^{7}, 324^{6}-25^{9}$

pennsylvanicus, $274^{1}, 323^{3}-24^{6}$

pinetorum, $326^{2}-27^{1}$

scalopsoides, $274^{2}, 326^{1}-27^{1}$ xanthognathus, $273^{7}$

Mink, northeastern, $350^{5}$ southeastern, $275^{5}, 350^{9}-5 \mathrm{I}^{8}$

Mole, hairy-tailed, $274^{3}, 363^{2}-64^{3}$ naked-tailed, $362^{3}-63^{1}$ star-nosed, $364^{3}-65^{2}$

Moose, $302^{8}$ 


Mouse, Canadian white-footed, $275^{8}$, $316^{6}-17^{6}$

common red-backed, $318^{8}-2 \mathrm{I}^{4}$

Gull Island, $275^{7}, 324^{6}-25^{9}$

house, $313^{1}$

jumping, $275^{3}, 329^{5}-31^{5}$

meadow, $273^{8}, 274^{1}, 323^{3}-24^{0}$

New Jersey red-backed, $275^{7}$, $321^{4}-22^{3}$

northeastern white-footed, $315^{2}$ $16^{5}$

northern pine, $274^{2}, 326^{1}-27^{1}$

red-backed, $274^{1}$

Muts americanus, $273^{9}, 314^{6}-15^{2}$

decumanus, $313^{8}-14^{5}$

leucopus, $3 \mathrm{I}^{3}-\mathrm{I}^{6}$

monaxt, $308^{7}-9^{7}$

musculus, $33^{\mathrm{T}}$

pennsylvanicus, $323^{3}-24^{8}$

rattus, $273^{9}, 314^{5}-15^{2}$

[sylvaticus] $\triangle$ noveboracensis, $315^{2}-16^{5}$

volans, $309^{8}-\mathrm{IO}^{7}$

Muskrat, $327^{2}-28^{2}$

Mustela americana, $353^{7}-54^{2}$

canadensis, $354^{3}$

cicognanii, $35 \mathrm{I}^{8}-52^{5}$

fusca, $273^{9}, 352^{1}$

hudsonica, $347^{2}-48^{8}$

lutra canadensis, $347^{7}-48^{8}$

lutreocephala, $350^{3}-5 \mathrm{I}^{8}$

martes, $353^{7}-54^{2}$

pennanti, $354^{3}$

pusilla, $352^{1}$

vison, $350^{5}$

Myotis lucifugus, $274^{4}, 365^{2}-66^{4}$

subulatus, $274^{3}, 366^{4}-67^{2}$

Napaeozapus insignis, $275^{8}, 330^{9}-31^{5}$

Neosorex albibarbis, $357^{3}$

Neotoma floridana, $274^{3}, 317^{7}-18^{7}$ magister, $3 \mathbf{I} 7^{7}-18^{7}$ pennsylvanica, $274^{3}, 317^{8}-18^{7}$

Newburgh mastodon, $375^{\prime \prime}$

Odocoileus americanus, $299^{8}-300^{8}$

Opossum, $273^{7}, 293^{3}-95^{1}$

Orca gladiator, $296^{7}$ orca, $296^{\circ}$

Otisorex platyrhinus, $273^{9}, 359^{4}-60^{4}$

Otter, northeastern, $347^{\circ}-48^{\circ}$

Panther, northeastern, $336^{4}-39^{8}$

Parascalops breweri, $274^{3}, 363^{2}-64^{8}$

Peccary, fossil, $372^{2}$

Peromyscus canadensis, $275^{3}, 316^{5}$ $17^{6}$

leucopus, $315^{4}-16^{5}$ myodes, $315^{4}-16^{5}$

noveboracensis, $315^{2}-16^{8}$

Phoca concolor, $355^{7}-56^{8}$

cristata, $356^{8}-57^{8}$

vitulina, $355^{8}-56^{8}$
Phocaena communis, $295^{7}-96^{2}$ orca, $296^{\circ}$ phocaena, $295^{7}-96^{2}$

Physeter macrocephalus, $297^{2}$

Pipistrellus subflavus obscurus, $275^{7}$, $368^{8}$

subflavus, $275^{6}, 368^{2}$

Plants of Canadian zone, $284^{1}-85^{2}$

of Hudsonian zone, $282^{6}$

of transition zone, $287^{1}-88^{7}$

of upper austral zone, $290^{4}-92^{3}$

Platigonus compressus, $372^{2}$

Porcupine, Canada, $331^{5}-32^{5}$

Porpoise, $273^{8}, 275^{2}, 295^{2}$ harbor, $295^{7}-96^{2}$

Procyon lotor, $354^{9}-55^{6}$

Pteromys volucella, $309^{8}-\mathrm{I} \mathrm{I}^{5}$

Putorius agilis, $353^{1}$

cicognanii, $351^{8}-52^{8}$

erminea, $353^{1}$

(Lutreola) vison lutreocephalus, $35 \mathrm{I}^{2}$

nigrescens, $350^{6}$

noveboracensis, $352^{8}-53^{6}$

richardsoni cicognani, $273^{\circ}, 352^{2}$

vison, $350^{6}, 350^{9}-51^{8}$

lutreocephalus, $275^{5}, 350^{9}-5 \mathrm{I}^{\mathrm{s}}$

vison, $350^{\circ}$

vulgaris, $352^{1}$

Raccoon, $354^{\circ}-55^{\circ}$

Rangifer caribou, $273^{8}$

tarandus, $273^{\mathrm{S}}$

Rat, black, $273^{9}, 314^{5}-15^{2}$

cave, $274^{3}, 317^{6}-18^{7}$

house, $3 \mathrm{I} 3^{8}-\mathrm{I} 4^{6}$

Red fox, $342^{4}-43^{1}$

Red squirrel, Canadian, $302^{7}-3^{5}$ southeastern, $275^{5}, 303^{6}-4^{6}$

Rorqualus borealis, $273^{8}$ rostratus, $296^{\circ}-97^{2}$

Scalops aquaticus, $362^{3}-63^{1}$

aquaticus, $363^{2}-64^{3}$

breweri, $274^{3}, 363^{2}-64^{3}$

Scapanus americanus, $363^{3}-64^{3}$

Scirurus hudsonicus loquax, $303^{\circ}-4^{6}$

Sciuropterus sabinus, $3 \mathrm{IO}^{9}-\mathrm{II}^{5}$ sabrinus macrotis, $274^{8}, 310^{8}-\mathrm{II}^{5}$ volans, $309^{8}-10^{7}$

volucella, $309^{8}-10^{7}$

hudsonius, $31 \mathrm{IO}^{8}-\mathrm{II}^{5}$

Sciurus carolinensis leucotis, $273^{\circ}$, $304^{7}-6^{3}$

var. leucotis, $304^{3}-6^{3}$

hudsonicus, $302^{3}-4^{8}$

gymnicus, $302^{7}-3^{5}$

loquax, $275^{5}$

leucotis, $304^{7}-6^{8}$

ludovicianus vicinus, $306^{\circ}$ 
(Tamias) lysteri, $307^{8}-8^{8}$

niger, $273^{\circ}, 304^{\top}-6^{3}$ cinereus, $306^{4}$

striatus, $307^{1}, 307^{8}-8^{6}$

vulpinus, $306^{4}$

Scotophilus fuscus, $369^{2}$ georgianus, $368^{\circ}$ noctivagans, $367^{4}-68^{2}$

Seal, harbor, $355^{6}-56^{8}$

hooded, $356^{8}-57^{3}$

Shrew, big-tailed, $275^{6}, 38^{6}-59^{4}$

Hoy's, $275^{4}, 360^{4}$

masked, $273^{9}, 359^{4}-60^{4}$

short-tailed, $273^{3}, 360^{7}-62^{3}$

small, $273^{7}$

smoky, $274^{8}, 357^{7}-58^{5}$

water, $275^{3}, 357^{3}$

Sibbaldius borealis, $273^{8}$

Sitomys americamis canadensis, $316^{7}$. $17^{\mathrm{B}}$

Skunk, $348^{6}-49^{9}$

Sorex albibarbis, $275^{3}, 357^{3}$

brevicaudus, $360^{8}-62^{3}$

carolinensis, $273^{7}, 360^{0}-62^{3}$

cooperi, $359^{5}-60^{4}$

cristatus, $364^{4}-65^{2}$

dekayi, $273^{8}, 360^{8}-62^{3}$

forsteri, $359^{4}-60^{4}$

fumeus, $274^{8}, 357^{7}-58^{5}$

hoyi, $275^{4}, 360^{4}$

macrurus, $275^{8}, 358^{8}-59^{4}$

parvus, $273^{7}$

personatus, $273^{9}, 359^{4}-60^{*}$

plaiyrhinus, $274^{8}, 357^{7}-58^{3}$

Squirrel, Canadian red, $302^{7}-3^{5}$ flying, $274^{8}, 309^{8}-\mathrm{II}^{5}$

fox, $306^{4}$

gray, $273^{9}, 304^{7}-6^{3}$

red, $275^{\circ}$

southeastern red, $303^{6}-4^{6}$

Stemmatopuis cristatus, $356^{9}-57^{3}$

Synaptomys cooperi, $275^{5}, 328^{2}$

fatuts, $275^{8}, 329^{1}$

Tamias striatus, $307^{2}, 307^{\circ}-8^{\circ}$ lysteri, $274^{8}, 307^{8}-8^{8}$ striatus, $307^{3}$

Transition zone, $282^{1}, 285^{2}-89^{6}$
Tursiops tursio, $275^{2}, 295^{2}$

Type localities in New York, 279'$80^{3}$

Upper austral zone, $282^{1}, 289^{6}-92^{4}$

Urocyon cinereoargenteus, $341^{3}-42^{4}$ virginianus, $34 \mathrm{I}^{7}-42^{4}$

Ursus americanus, $347^{1}$ lotor, $354^{9}-55^{6}$

luscus, $350^{1}$

Vespertilio auduboni, $367^{3}-68^{2}$

borealis, $370^{7}-7 \mathrm{I}^{6}$

fuscus, $369^{1}$

georgianis, $368^{3}$

gryphus, $365^{4}-66^{4}$

linereus, $369^{\circ}-70^{\circ}$

lucifugus, $365^{3}-66^{4}$

noctivagans, $367^{3}-68^{2}$

noveboracensis, $370^{7}-71^{6}$

pruinosus, $369^{9}-70^{8}$

subflarus, $368^{3}$

subulatus, $274^{4}, 365^{3}-66^{4}, 366^{5}-67^{2}$

Vesperugo carolinensis, $368^{4}, 369^{1}$

fuscus, $369^{8}$

georgianus, $368^{4}$

noctivagans, $367^{5}-68^{2}$

serotinus fuscus, $369^{2}$

Viverra mephitica, $348^{8}-49^{\circ}$

Vole, rock, $275^{5}, 322^{3}-23^{3}$

Vulpes fulvus, $342^{4}-43^{1}$ pennsylvanicus, $342^{5}-43^{1}$

virginianus, $34 \mathrm{I}^{7}-42^{4}$

vulgaris penusylvanicus, $342^{5}-43^{1}$

Wapiti, eastern, $300^{9}-2^{3}$

Weasel, Bonaparte's, $273^{9}, 351^{8}-52^{8}$ New York, $352^{8}-53^{6}$

Whale, bottle-nosed, $296^{8}-97^{2}$ right, $297^{5}$

silver-bottom, $273^{8}$

sperm, $297^{2}$

Wildcat, $340^{6}-4 \mathrm{I}^{5}$

Wolf, timber, $343^{2}-46^{\circ}$

Wolverine, $350^{1}$

Woodchuck, $308^{7}-9^{7}$

Zapus hudsonius, $329^{8}-30^{8}$

hudsonius, $330^{9}-3 \mathrm{I}^{5}$

insignis, $330^{\circ}-31^{6}$ 




\section{New York State Museum PUBLICATIONS}

Museum reports. New York state museum. Annual report, $1847-$ date. O. Albany I 848-date.

Average 300 pages a year. Price for all in print to $18 \mathrm{~g} 2,50$ cents a volume; 75 cents in cloth;
$1892-$ date, 75 cents, cloth.

Museum bulletins. New York state museum. Bulletin. v. I-6, O. Albany 1887 -date. Frice to advance subscribers, 75 cents a year.

Volume 1. 6 nos. Price $\$ \mathrm{r}$ in cloth

I Marshall, W: B. Preliminary list of New York unionidae. rgp. Mar. I892. Price 5 cents.

2 Peck, C:H. Contributions to the botany of the state of New York. 66 p. 2 pl. May i 887 . Price [35] cents.

3 Smock, J: C. Building stone in the state of $\mathrm{N} \in \mathrm{W}$ York. I $52 \mathrm{p}$. Mar. 1888. Out of print.

4 Nason, F. L. Some New York minerals and their localities. I9p. I pl. Aug. 1888. Price 5 cents.

5 Lintner, J. A. White grub of the May beetle. 3rp. il. Nov. I888. Price ro cents.

6 - Cut-worms. 36p. il. Nov. I888. Price ro cents.

Volume 2. 4 nos. Price $\$ \mathrm{r}$ in cloth

7 Smock, J: C. First report on the iron mines and iron ore districts in N. Y. $5+70$. map $58 \times 60 \mathrm{~cm}$. June 1889 . Price 20 cents.

8 Peck, C: H. Boleti of the U. S. 96p. Sep. 1889. Price [40] cents.

9 Marshall, W: B. Beaks of unionidae inhabiting the vicinity of Albany, N. Y. 23p. r pl. Aug. 189o. Price so cents.

ro Smock, J: C. Building stone in New York. 2 rop. map $58 \times 60$ $\mathrm{cm}$, tab. Sep. 1890 . Price 40 cents.

\section{Volume 3}

I I Merrill, F : J. H.. Salt and gypsum industries in New York. 92p. 2 maps $38 \times 58,6 \mathrm{I} \times 66 \mathrm{~cm}$, I 1 tab. I 2 pl. April I893. Price 40 cents.

I2 Merrill, F: J. H. \& Ries, H. Clay industries of New York. I74p. map $59 \times 67 \mathrm{~cm} .2$ pl. Mar. 1895. Price 30 cents. New edition in preparation.

I3 Lintner, J. A. Some destructive insects of New. York state; San José scale. 54p. 7 pl. Ap. 1895 . Price I 5 cents.

I4 Kemp, J. F. Geology of Moriah and IVestport townships, Essex co. N. Y., with notes on the iron mines. 38 p. 2 maps $30 \times 33,38 \times 44$ cm. 7 pl. Sep. 1895. Price ro cents.

I5 Merrill, F : J. H. Mineral resources of New York 224p. 2 maps $22 \times 35,5^{8} \times 65 \mathrm{~cm}$. Feb. 1896 . Price 40 cents.

\section{Volume 4}

I6 Beauchamp, W : M. Aboriginal chipped stone implements of New York. 86p. $23 \mathrm{pl}$. Oct. 1897. Price 25 cents.

I 7 Merrill, F : J. H. Road materials and road building in New York. 52 p. 2 maps $34 \times 44,68 \times 92 \mathrm{~cm}$. I4 pl. Oct. I897. Price I 5 cents.

I8 Beauchamp, W: M. Polished stone articles used by the New York aborigines. I04p. 35 pl. Nov, 1897 . Price 25 cents.

I9 Merrill, F: J. H. Guide to the study of the geological collections of the New York state museum. x62p. II pl. I map $33 \times 43 \mathrm{~cm}$. Nov. 1898 . Frice 40 sents. 


\section{Volume 5}

20 Felt, E. P. Elm-leaf beetle in New York. $46 \mathrm{p}$. il. 5 pl. - June I898. Price 5 cents.

2 I Kemp, J. F. Geology of the Lake Placid region. $33 \times 34 \mathrm{~cm}$. I pl. Sep. 1898 . Price 5 cents.

22 Beauchamp, W: MI. Earthenware of the New York aborigines. 78 p. 33 pl. Oct. 1898. - Price 25 cents.

23. Felt, E. P. I 4 th report of the state entomologist, I 898 . I 5 op. il. 9 pl. Dec. 1898 . Price 20 cents.

$24:$ Memorial of life and entomologic work of J. A. Lintner. 3 r6p: I pl. Oct. I899. Price 35 cents.

25 Peck, C: H. Report of the state botanist, r898. $76 \mathrm{p} .5 \mathrm{pl}$. Oct. I899. Price 40 cents.

Volume 6

26 Felt, E. P. Collection, preservation and distribution of New York insects. $36 \mathrm{p}$. Ap. 1899 . Price 5 cents.

27 Shade-tree pests in New York state. 26p. 5 pl. May 1899. Price 5 conts.

28 Peck, C: H. Plants of North Elba. 206p. I map $12 \times 16 \mathrm{~cm}$. June 1899 Price 20 cents.

29 Miller, G S., jr. Preliminary list of New York mammals. I24p. Oct. I899. Price I 5 cents.

30 Orton, Edward. Petroleum and gas in New York. In press.

Beauchamp, W: M. Aboriginal occupation of New York. In press. Cumings, E. R. Lower Silurian system of eastern Montgomery county; Prosser, C: S. Notes on the stratigraphy of the Mohawk valley and Saratoga county, N:Y. In preparation.

Ries, H. Clays : their properties and uses. In preparation.

Miller, G. S., jr. Key to the land mammals of N. E. North America. In preparation.

Economic map. Merrill, F: J. H. Economic and geologic map of the state of New York. $59 \times 67 \mathrm{~cm}$. 1894. Price, unmounted 25 cents, backed on muslin 75 cents.

Scale $x_{4}$ miles to $x$ inch. New edition in preparation.

Museum memoirs. New York state museum. Memoirs. v. I, Q. Albany 1889 .

Uniform with the Paleontology.

I Beecher, C: E., \& Clarke, J: M. Development of some Silurian brachiopoda. 95 p. 8 pl. Oct. r889. Price 80 cents.

2 Hall, James \& Clarke, J: M. Paleozoic reticulate sponges. 35\%p. il. 70 pl. Oct. 1899 . Price \$r.

3 Clarke, J: M. The Oriskany fauna of Becraft mountain, Columbia co. N. Y. In preparation.

Natural history. New York state. Natural history of New York. 30 v. il. pl. maps, Q. Albany I842-94.

Divisions $x-5$ out of print.

Division I De Kay, J. E. Zoology. 5 v. pl. $1842-44$.

" 2 Torrey, John. Botany. 2 v. 1843.

" 3 Beck, L.C. Mineralogy. 24+536p. il. pl. I842.

" 4 Mather, W: W.; Emmons, Ebenezer; Vanuxem, Lardner; \& Hall, James. Geology. 4 v. pl. maps. I 842-43.

" 5 Emmons, Ebenezer. Agriculture. 5 v. il. maps. 1846-54.

‘6 6 Hall, James. Paleontology. 8 v. il. pl. 1847-94. 





SMITHSONIAN INSTITUTION LIBRARIES

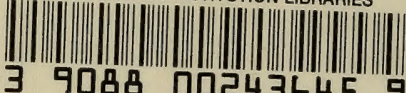

39088 00243645

Key to the land mamm . N M64

the land mammals of northeastern 